\title{
Keuren is mensenwerk : kwaliteitsaspecten van de medische keuring voor militairen binnen de Nederlandse krijgsmacht en voor dienstplichtigen in het bijzonder
}

Citation for published version (APA):

Reulings, P. G. J. (1996). Keuren is mensenwerk : kwaliteitsaspecten van de medische keuring voor militairen binnen de Nederlandse krijgsmacht en voor dienstplichtigen in het bijzonder. [Doctoral Thesis, Maastricht University]. Universiteit Maastricht. https://doi.org/10.26481/dis.19961212pr

Document status and date:

Published: 01/01/1996

DOI:

$10.26481 /$ dis. $19961212 \mathrm{pr}$

Document Version:

Publisher's PDF, also known as Version of record

Please check the document version of this publication:

- A submitted manuscript is the version of the article upon submission and before peer-review. There can be important differences between the submitted version and the official published version of record. People interested in the research are advised to contact the author for the final version of the publication, or visit the DOI to the publisher's website.

- The final author version and the galley proof are versions of the publication after peer review.

- The final published version features the final layout of the paper including the volume, issue and page numbers.

Link to publication

\footnotetext{
General rights rights.

- You may freely distribute the URL identifying the publication in the public portal. please follow below link for the End User Agreement:

www.umlib.nl/taverne-license

Take down policy

If you believe that this document breaches copyright please contact us at:

repository@maastrichtuniversity.nl

providing details and we will investigate your claim.
}

Copyright and moral rights for the publications made accessible in the public portal are retained by the authors and/or other copyright owners and it is a condition of accessing publications that users recognise and abide by the legal requirements associated with these

- Users may download and print one copy of any publication from the public portal for the purpose of private study or research.

- You may not further distribute the material or use it for any profit-making activity or commercial gain

If the publication is distributed under the terms of Article 25fa of the Dutch Copyright Act, indicated by the "Taverne" license above, 


\section{KEUREN IS MENSENWERK}

Kwaliteitsaspecten van de medische keuring

voor militairen binnen de Nederlandse krijgsmacht en voor dienstplichtigen in het bijzonder

P.G.J. Reulings 
[SBN 90-9010097-0

Vormgeving $\varepsilon$ Layout: Sectie Grafische Vormgeving, Frederikkazerne Den Haag Druk: Helton Van Haeringen \& Koninklijke Drukkerij De Swart

De uitgave van dit proefschrift kwam mede tot stand door bijdragen van het Ministerie van Defensie en Forum verzekeringmaatschappij. 


\section{KEUREN IS MENSENWERK}

Kwaliteitsaspecten van de medische keuring voor militairen binnen de Nederlandse krijgsmacht en voor dienstplichtigen in het bijzonder

\section{PROEFSCHRIFT}

ter verkrijging van de graad van doctor aan de Universiteit Maastricht, op gezag van de Rector Magnificus,

Prof. mr. M.J. Cohen, volgens het besluit van het College van Dekanen, in het openbaar te verdedigen op donderdag 12 december 1996 om 14.00 uur

door

Petra Reulings 


\section{Promotores:}

Prof. dr. H.F.J.M. Crebolder

Prof. dr. F. Sturmans

\section{Co-promotor:}

Dr. F.G. van der Horst

\section{Beoordelingscommissie:}

Prof. dr. F.J.M. Nijhuis (voorzitter)

Dr. J.P.M. Diederiks

Prof. dr. Sj. van der Linden

Prof. dr. J.M.L.M. Soeters (KMA, Breda)

Prof. dr. M.W. de Vries 


\section{INHOUDSOPGAVE}

Introductie

1 Keuren in het algemeen, en keuringen bij de krijgsmacht in het bijzonder

1.1 De betekenis van keuren 6

1.1.1 keuren in het algemeen 6

1.1.2 de aanstellingskeuring 7

1.1.3 de anstellingskeuring bij de krijgsmacht 9

1.1.4 de dienstplichtkeuring 11

1.1.5 onderscheid tussen keuringen in de burgermaatschappij en de krijgsmacht 15

1.1.6 nieuwe ontwikkelingen binnen de krijgsmacht 19

1.2 De kwaliteit van keuringen $\quad 21$

1.2.1 inleiding 21

1.2 .2 reproduceerbaarheid 21

$\begin{array}{lll}1.2 .3 & \text { validiteit } & 23\end{array}$

$\begin{array}{ll}\text { 1.2.4 praktische (on)mogelijkheden } & 25\end{array}$

$\begin{array}{lll}1.3 & \text { Vraagstellingen } & 26\end{array}$

$\begin{array}{ll}1.4 & \text { De structuur van het proefschrift }\end{array}$

2 Medisch disfunctioneren $\quad 30$

2.1 Het keuringstraject voor dienstplichtigen van de Koninklijke Landmacht 30

2.2 Prognostische lactoren van het medisch disfunctioneren tijdens militaire 37 dienst bij de Koninklijke Landmacht

3.1 Medisch keuren is mensenwerk. Variatie tussen artsen bij de beoordeling van de geschiktheid voor militaire dienst

3.2 Reproduceerbaarheid van de beoordeling bij dienstplichtkeuringen 56

3.3 Reproduceerbaarheid van de beoordeling bij periodiek geneeskundig 65 onderzoek van de Koninklijke Landmacht 
$\begin{array}{ll}\text { 4.1 Belangrijkste bevindingen } & 77\end{array}$

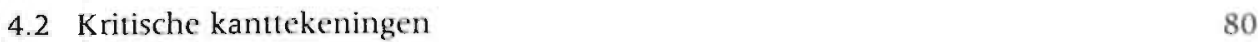

4.3 De beschikbaarheid en bruikbaarheid van keuringsgegevens voor 90 wetenschappelijk onderzoek

4.4 Aanbevelingen ter verbetering van de kwaliteit van de militaire keuring en voor verder onderzoek

Bijlage 1

Bijlage 2 



\section{INTRODUCTIE}

Het grootste gedeelte van de medische keuringen die binnen het Ministerie van Defensie plaatsvinden, geschiedde tot voor kort in het kader van de Dienstplichtwet '; iedere Nederlandse man onderging rond zijn 18 de levensjaar een keuring waarbij de geschiktheid voor militaire dienst werd vastgesteld. In 1994 zijn 78.935 dienstplichtkeuringen verricht.

Al enige tijd bestond de behoefte om de militaire keuring aan een kritisch onderzoek te onderwerpen en waar mogelijk de kwaliteit te verbeteren. In 1985 tijdens de eerste vergadering van het Subcomité Militaire Keuringen werd aangegeven dat 'beoordeling van de kwaliteit van de keuringen pas mogelijk is indien achteraf wordt nagegaan wat de resultaten van de keuringen zijn (afvalpercentage in dienst). Voorgesteld wordt een onderzoek te starten omtrent dit afvalpercentage...'. In 1990 is de eerste actie ondernomen en heeft een dienstplichtige enige maanden onderzoek verricht. Daarnaast hebben door de jaren heen keurend artsen in het kader van hun opleiding tot verzekeringsgeneeskundige of bedrijfsgeneeskundige kleinschalig onderzoek verricht. Het duurde echter tot medio 1992 voordat er voldoende capaciteit beschikbaar was om het project 'Relatie Defensiekeuringen' te starten binnen de Directie Dienstplichtzaken van het Ministerie van Defensie. Dit project dat oorspronkelijk twee jaar zou duren, is verlengd tot vier jaar. Het doel van dit project is, op basis van wetenschappelijk onderzoek omtrent de verschillende geneeskundige onderzoeken van dienstplichtigen, te komen tot eventuele aanbevelingen voor kwaliteitsverbetering van keuringen.

In eerste instantie leek het wenselijk om (met de centraal geregistreerde gegevens) naar verbanden te zocken tussen de uitslag van de eerste keuring en het vervolgtraject van de dienstplichtigen. Deze resultaten konden dienen als terugkoppeling aan de keurend arisen die hiermee een middel in handen zouden krijgen om de kwaliteit van de keuring te verbeteren. Een beter keuringsbeleid zou kunnen leiden tot een afname van het aantal medische disfunctioneerders in werkelijke dienst. Medische disiunctioneerders zijn dienstplichtigen die tijdens werkelijke dienst om medische redenen niet functioneren en derhalve ongeschikt worden verklaard. Uiteindelijk is er evenwel voor gekozen om de kwaliteit van de keuring vanuit een breder perspectief te bestuderen. Dit wordt in het eerste hoofdstuk toegelicht.

Tijdens de beginperiode van het project kwam de discussie op gang over een grootschalige reorganisatie binnen het Ministerie van Defensie. Reden hiervoor was het einde van de Koude Oorlog en de daarmee samenhangende politieke veranderingen. Het gevolg was dat de taken van de krijgsmacht veranderden. 'In het licht van deze nieuwe situatie heeft de regering besloten verder op de defensie-uitgaven te bezuinigen'2. Dit houdt, naast de herstructurering, ook een inkrimping van de krijgsmacht in. Het gevolg hiervan is dat de opkomstplicht is opgeschort. De laatste dienstplichtigen hebben 22 augustus 1996 de dienst verlaten. De dienstplicht is derhalve niet afgeschaft, maar de opkomstplicht van dienstplichtigen in werkelijke dienst is opgeschort. De Dienstplichtwet blijft gehandhaafd en kan bij oorlogsdreiging of calamiteiten opnieuw in werking treden. 
De krijgsmacht besiaat uit de Koninklijke Landmacht (inclusief de Koninklijke Marechaussee), Koninklijke Luchtmacht (KLU) en de Koninklijke Marine (KM). De Koninklijke Landmacht (KL) vormt het grootste krijgsmachtdeel. In 1994 had de KL. 54.500, de KLU 17.650 en de KM 20.560 mensen personeel in dienst. De reorganisatie heeft voor de Koninklijke Landmacht de meest ingrijpende consequenties, omdat een groot deel van het personeel dienstplichtig was. In 1994 diende $41 \%$ bij de KL als dienstplichtig militair, bij de KLU 15\% en bij de KM 5\%. In het jaar 2000 dient de omvang van de KL te zijn verminderd tot 36.200 personen, waarvan 10.800 beroepsmilitairen voor onbepaalde tijd, 14.700 beroepsmilitairen voor bepaalde tijd en 10.700 burgers $^{2}$.

Vanzelfsprekend heeft de opschorting van de dienstplicht geleid tot de vraag of er nog behoefte bestond aan het onderhavige onderzoek. De argumenten om die vraag positief te beantwoorden, kunnen als volgt worden samengevat. De dienstplichtkeuring is te beschouwen als een bijzondere vorm van een aanstellingskeuring. In de burgermaatschappij kunnen de resultaten relevant zijn voor aanstellingskeuringen van functies die ook een verhoogd gezondheids- en veiligheidsrisico voor zichzelf en anderen met zich meebrengen, zoals bij de politie en de brandweer. Bij recent onderzoek naar aanstellingskeuringen zijn militaire keuringen steeds buiten beschouwing gebleven ${ }^{3.7}$.

De huidige keuringsprocedure van de dienstplichtkeuring vormt tevens de basis voor de medische keuringen van het beroepspersoneel. De resultaten van onderzoek bij diensiplichtkeuringen kunnen ook relevant zijn voor alle andere militaire keuringen, waarbij ook de dienstgeschiktheid dient te worden vastgesteld. Ondanks het gegeven dat het onderhavige onderzoek grotendeels dienstplichtkeuringen betreft, wordt in de titel van het proefschrilt al aangegeven dat het niet alleen dienstplichtkeuringen betreft, maar militaire keuringen in her algemeen.

\section{Literatuur}

1 Kiewit CC. Dienstplichrwet: Wet van 4 febr 1922, Stb 43.-9e dr.- Zwolle: Tjeenk Willink, 1990.

2 Ministerie van Defensie. Prioriteitennota. Den Haag, 1993.

3 Kort WLAM de. Personne] selection through pre-employment medicals [proctschrift]. Universiteit van Amsterdam, 1993.

4 Jansen J, Lourijsen ECMP, e.a. Een verkenning van voorspellend onderzoek in keuringssituaties. Bilthoven: RIVM, 1993.

5 Commissie Medische Keuringen. Keuren en voorspellen. Den Haag: Gezondheidsraad, 1993.

6 Lourijsen ECMP, Heuvel SG van den, e.a. De praktijk van de medische aanstellingskeuring in 1988 en 1992. Den Haag: Ministerie van Sociale Zaken en Werkgelegenheid, 1993.

7 Ministerie van Sociale Zaken en Werkgelegenheid. De praktijk van medische unnstellingskeuringen 1993. Den Haag, 1994. 


\section{KEUREN IN HET ALGEMEEN, EN KEURINGEN IN HET BIJZONDER}

\subsection{De betekenis van keuren}

\subsubsection{Keuren in het algemeen}

Bij elke keuring vindt een waardebepaling plaats en wordt bekeken of het te keuren object voldoet aan de vereiste kwaliteit.

Bij medische keuringen van personen wordt de gezondheidstoestand van de te keuren persoon, de zogenaamde keurling, vastgesteld. In het algemeen wordt tijdens de medische keuring bepaald of de gezondheidstoestand aan bepaalde eisen voldoet. De eisen zijn afhankelijk van het soort keuring. Er zijn verschillende soorten medische keuringen: pensioenkeuringen, keuringen in verband met risico's voor derden, risicokeuringen ten behoeve van verzekeringen, risicokeuringen ter verkrijging van een bevoegdheid of een toelating, keuringen op verwoek van de betrokkenen zoals sportkeuringen, aanstellingskeuringen en periodieke keuringen'.

De maatschappij draagt zorg voor personen die niet (meer) deelnemen aan het arbeidsproces. In de eerste helft van deze eeuw is financiële ondersteuning bij invaliditeit, ziekte en pensioen wettelijk geregeld. Wil men in aanmerking komen voor deze voorzieningen, dan moet men gekeurd worden. De keuring is dan een middel om te selecteren wie wel of geen aanspraak kan maken op de voorziening. De keurend arts is daarbij de poortwachter: hij beslist over het verkrijgen van het 'schaarse' goed, namelijk: de linanciële vergoeding als gevolg van het niet meer kunnen werken. De keuring is daarmee tevens een middel om het financiële risico voor de werkgever en/of de overheid te bewaken. Parallel hiermee loopt de volgende visie (De Swaan) ": 'Bij het vaststellen van de arbeidsgeschiktheid gaat het in beginsel om omstreden belangenafweging die wordt afgewikkeld als een kwestie van medische expertise ... Analoog is de werking van medische adviezen bij selectie van mensen, of het nu gaat om de militaire dienst of om aanstellingen in het bedrijfsleven: de keurend arts krijgt een veto toegewezen dat in allerlei gevallen kan dienen om de organisatie voor een reeks van conflicten te behoeden. Waar die selectie minder omstreden is, geringere consequenties heeit, zoals bij sport- en verkeerskeuringen zal het medisch advies ook specifieker, zakelijker zijn, ondat het immers geen conflict beheersende functic behoeft te vervullen (maar zodra het conflictpotenticel weer toencemt, zoals bij de doping-onderroek, wordt ook de medische expertise weer uitgerekt tot ver voorbij de grem/en waarbinnen ze nog geldig is)'.

Ondanks de enorme vooruitgang van de medische wetenschap zijn er grenzen aan de medische expertise om de gezondheidstoestand van de persoon in kwestie te beoordelen, aangezien niet alle ziekten en gebrekcu in alle stadiu mogen en kunnen worden vasigesteld. Omdat slechts een beperkt aantal onderzoeksmethoden toelaatbaar is, kunnen niet alle aandoeningen worden geconstatecrd. Immers, er mag geen onevenredige inbreuk worden gemaakt op de fysieke en psychische integriteit en persoonlijke levenssîfer van een persoon. Daarnaast is men niet in staat aandoeningen (in alle stadia) te constateren, omdat de keuring 
een momentopname is. Een persoon kan van de ene op de andere dag ziek worden, bijvoorbeeld door toevalsfactoren die de arts niet kan voorzien. Voor aanstellingskeuringen geldt bovendien dat de mogelijkheden om ziekten en gebreken te voorspellen beperkt zijn.

Een aanstellingskeuring kan worden beschouwd als een preventieve maatregel ter voorkoming van ziekten of ongevallen van de betrokken persoon en derden (als gevolg van arbeid). Bij de beroepsuitoefening bij de politie, brandweer en krijgsmacht is, naası de bescherming van de gezondheid en veiligheid van de persoon zelf, de bescherming van derden extra belangrijk. Zo is een gezond leger een essentiële voorwaarde om de veiligheid van de bevolking te kunnen waarborgen.

In deze studie wordt ingegaan op de vraag of door de militaire aanstellingskeuring de juiste mensen in dienst komen. Maar eerst worden diverse aspecten besproken van aanstellingskeuringen in het algemeen en voor de krijgsmacht in het bijzonder.

\subsubsection{De aänstellingskeuring}

De laatste decennia speelt er een discussie over de aanstellingskeuring. Bescherming van de kwetsbare positie van de keurling en onderzoek naar de mate waarin de aanstellingskeuring leidt tot het plaatsen van de juiste persoon op de juiste plek, zijn onderwerpen op de politieke agenda.

De aanstellingskeuring is geen wettelijke verplichting. Wel is een aantal aanstellingskeuringen privaatrechtelijk verplicht. Deze keuringen zijn vastgelegd in de arbeidscontracten. De werknemer moet de keuring ondergaan als de werkgever daar een, al dan niet in het contract omschreven, aanleiding toe heeft. Ook komen bepalingen omtrent aanstellingskeuringen voor in $\mathrm{CAO}^{\prime}$ '.

Naar aanleiding van de Motie Vellinga woedde in de jaren zeventig een politieke discussie over de bescherming van de sollicitant bij psychologisch onderzoek en medische keuringen. De Commissie Van Hessel werd ingesteld met het doel voorstellen te doen ter verbetering van de bescherming van de sollicitant. Resultaat is het rapport 'Een sollicitant is ook een mens' van $1977^{\prime}$. In de jaren tachtig kreeg de Interdepartementale Werkgroep Selectieprocedures de opdracht de uitgangspunten van de commissie Van Hessel tot een wettelijke maatregel uit te werken. In afwachting daarvan stelde de Stichting van de Arbeid in 1982 aanbevelingen vast met betrekking tot regelingen inzake werving en selectie. De regering zag echter af van een wettelijke maatregel omdat zij groot belang hechtte aan de eigen verantwoordelijkheid van werkgevers en werknemers. Het voomemen was de ontwikkelingen in deze een paar jaar later te evalueren om op basis daarvan opnieuw te bekijken of een wettelijke regeling alsnog wenselijk zou zijn. In $1992 \mathrm{kwam}$ de politieke partij D'66 met een voorontwerp initiatief wetsvoorstel om de medische keuringen aan banden te leggen. In 1993 werd het wetsvoorstel 'Wet op de medische keuringen' volgens het concept van de 'geconditioneerde zelfregulering' ingediend". Volgens dit concept legt de wetgever enkele grondlijnen en kunnen de vertegenwoordigers van de betrokken partijen binnen dat raamwerk tot zelfregulering overgaan door regels en normen uit te werken in overeenkomsten tussen de betrokken partijen ". 
Gelijktijdig kwam de 'medische keuring als geschikt selectie-instrument' vanaf 1988 in de politiek aan de orde. Dit werd veroorzaakt door de commotie over onderzoek naar seropositiviteit voor de ziekte AIDS. Vragen over het gebruik van de HIV-test in relatie tot keuringen hebben tot een aantal rapportages geleid. Door de KNMG is in 1989 de discussienota over keuringen gepubliceerd en in 1991 het rapport 'Risicokeuringen in medische perspectief' $7-8$. In 1989 is het rapport 'Goed Gekeurd' van de Interdepartementale Werkgroep Aanstellingskeuringen verschenen waarin de procedurele en juridische problematiek van de medische aanstellingskeuringen in beeld zijn gebracht 4. In 1992 werd tijdens een vergadering van de vaste kamercommissie Volksgezondheid en Justitie over het AIDS-beleid gevraagd om een beoordeling van medisch voorspellend onderzoek. Het voornemen van het kabinet om in 1993 tot conclusies te komen heeft geleid tot twee rapporten: 'Een verkenning van voorspellend onderzoek in keuringssituaties' van het TNO/NIPG en de reactie van de Gezondheidsraad op dit onderzoek onder de naam 'Keuren en voorspellen' ${ }^{1-9}$. Tevens heeft in 1993 een herhaling plaatsgevonden van het onderzoek naar de praktijk van de medische aanstellingskeuring van 1988 en $1992^{10-11}$. In 1993 verscheen het proefschrift van De Kort waarin de aansteliingskeuring als selectie-instrument nader is onderzocht ${ }^{12}$

Belangrijke conclusies van deze onderzoeken zijn:

- Het totaal aantal verrichte aanstellingskeuringen ligt in 1988 rond de 325.000 en is in 1991 gedaald tot $250.000^{\circ 0}$.

- Bij aanstellingskeuringen bij de rijksoverheid werd over het geheel $0.6 \%$ afgekeurd. Voor de functies waarbij de openbare orde en veiligheid een rol spelen of de fysieke belasting hoog is, is het percentage afkeuringen hoger, mar niet hoger dan $4 \%$.

- De voorspellende waarde van de aanstellingskeuring is maar van beperkte betekenis. Mede door dit lage afkeuringspercentage en de geringe voorspellende waarde zijn deze aanstellingskeuringen alleen wenselijk of noodzakelijk voor werk met grote gezondheids- en veiligheidsrisico's voor betrokkene of derden ${ }^{22}$.

Door de invoering van de Wet Terugdringing Zickteverzuim en de Wet Terugdringing Arbeidsongeschiktheidsvolume is in 1994 de discussie over de aanstellingskeuringen weer ongelaaid. Deze wetten geven de werkgevers een grotere verantwoordelijkheid als een werknemer ziek of arbeidsongeschikt wordt. De werkgevers lopen daarmee ook een groter financieel risico. Een goede voorspelling over het te verwachien ziekteverzuim en arbeidsongeschiktheid van nieuw personeel is daarom door de werkgever gewenst. Omdat de voorspellende waarde van de keuring gering is, achtte de overheid het niet wenselijk de keuring te hanteren als een risico-inschatting van ziekteverzuim en arbeidsongeschiktheid, tenzij daarvoor een strikte rechtvaardiging bestaat. Daarom is door de Koninklijke Nederlandse Maatschappij tot bevordering der Geneeskunst (KNMG), op advies van het Ministerie van Sociale Zaken en Werkgelegenheid, het 'Protocol Aanstellingskeuringen' opgesteld. Dit Protocol past goed binnen het principe van de geconditioneerde zelfregulering: de betrokken partijen zijn zelf verantwoordelijk voor de verdere uitwerking. De drie partijen zijn de keurling, de keurend arts en de opdrachtgever. Het Protocol Aanstellingskeuringen is in werking gerreden op l januari $1996^{\circ}$.

In het Protocol is het doel van de aanstellingskeuring gewijzigd. Doel van de keuring is te bepalen of de belastbaarheid van de keurling overeenstemt met de belasting voor de 
betreffende functie. De belastbaarheid wordt beoordeeld op het moment van de keuring.

Daarbij zal het voorkomen van schade voor de gezondheid, de bescherming van de veiligheid van de keurling alsmede de veiligheid van derden bij de uitvoering van de betreffende arbeid worden betrokken.

Verder zijn in het Protocol beschreven: de voorwaarden waaronder een aanstellingskeuring moet plaatsvinden, de informatieverstrekking, de rapportage en verslaglegging, de herkeuring en een klachtenprocedure.

- Voorwaarde voor een aanstellingskeuring is de aanwezigheid van specifieke functieeisen, die tevens geformuleerd zijn in medische termen;

De keurend arts moet voldoende kennis en vaardigheden bezitten om de belastbaarheid ten opzichte van de te verwachten belasting voor de functie te kunnen beoordelen;

De aanstellingskeuring moet dienen om informatie te verkrijgen over de huidige belastbaarheid ten opzichte van de belasting door de functie;

Een aanstellingskeuring dient te worden verricht nadat de werkgever van plan is de keurling aan te nemen;

Voorspellend onderzoek mag alleen worden uitgevoerd als voldaan is aan de volgende criteria: relevantie (het onderzoek draagt bij aan het doel van de keuring), subsidiariteit (er is geen andere, betere en minder ingrijpende of belastende methode beschikbaar) en proportionaliteit (het te verrichten onderzoek staat in redelijke verhouding tot het doel van het onderzoek) *

In dit Protocol word benadrukt dat de keuring geen risico-keuring is, maar een keuring die de geschiktheid op het moment van de keuring vaststelt. Een keuring zonder functie-eisen heef́t dan ook geen zin.

De praktijk wijst uit dat sinds de invoering van de Wet Terugdringing Ziekteverzuim het aantal aanstellingskeuringen flink is gestegen ${ }^{13}$. Volgens het rapport 'Risicoselectie op de arbeidsmarki' hebben de getroffen matregelen als ongewenst effect dat risicoselectie op gezondheid of (verondersteld) ziekteverzuim bij de aanname van personeel is toegenomen. Huisartsen, die minder dan de helf van de aanstellingskeuringen verrichten, keuren ongeveer hetzelfde percentage af $(1,4 \%$ afkeuringen in 1991 en $1.2 \%$ in 1993). Echter, bij degenen die door de bedrijfsartsen zijn gekeurd, is het afkeuringspercentage toegenomen van $1.8 \%$ in 1991 naar $5 \%$ in $1993^{\prime 4}$. De rol van de arts als 'poortwachter' is derhalve versterkt. Duidelijk mag zijn dat het Protocol Aanstellingskeuringen op zichzelf onvoldoende is om - de al dan niet chronisch - zieken en gehandicapten wettelijk te beschermen. Voor deze bescherming dient het wetsvoorstel op de medische keuringen te worden aangenomen ?

\subsubsection{De aanstellingskenringen bij de krijgsmacht}

Binnen het Ministerie van Defensie worden voor beroepsmilitairen, en tot voor kort voor dienstplichtigen, keuringen verricht om de lichamelijke en geestelijke geschiktheid voor militaire dienst vast te stellen. Dienstplichtigen vallen voor opkomst onder de Directie Dienstplichtzaken, die ook verantwoordelijk is voor de keuring. Na opkomst vallen zij onder één van de krijgsmachtdelen waar zij eventueel een aanvullende keuring ondergaan. De beroepsmilitairen zijn tot 1 april 1996 bij het keurings- en selectiecentrum van het desbetreffende krijgsmachtdeel gekeurd: de Koninklijke Landmacht (KL). Koninklijke Luchtmacht (KLU) of 
Koninklijke Marine (KM). Momenteel wordt door de Defensie-organisatie voor Werving en Selectie (DWS) de werving en selectie van de beroepsmilitairen van alle krijgsmachtdelen centraal geregeld.

De Directie Dienstplichtzaken en de drie krijgsmachtdelen voeren in grote lijnen hetzelfde beleid. Zij hanteren het Militair Keuringsreglement (MKR), waarin de eisen voor lichamelijke en geestelijke geschiktheid voor de militaire dienst zijn vastgelegd ${ }^{15}$.

Door het bijzondere karakter van de militaire organisatie, zijn de eisen die aan militairen gesteld worden anders dan die bij burgers. De militair dient in staat te worden geacht de in oorlogssituatie voorkomende functies te vervullen. De eisen zijn gerelateerd aan de functievervulling in oorlogstijd ${ }^{16}$.

Volgens de Prioriteitennota zijn de hoofdtaken van de krijgsmacht:

de uitvoering van crisisbeheersingsoperaties in het kader van het Nederlandse veiligheidsbeleid;

de bescherming van de integriteit van het eigen en bondgenootschappelijk gebied en het optreden tegen een bedreiging van het eigen territoir als gevolg van deelneming aan crisisbeheersingsoperaties (peace-keeping en peace-enforcing VN-operaties) ${ }^{17}$.

Door verschuiving van de taken binnen de krijgsmacht, veranderen ook de functies en daarmee ook de functic-cisen van het personeel.

Functies die in vredestijd worden uitgevoerd, zijn slechts ten dele te vergelijken met de functies in oorlogstijd. Dit maakt het moeilijk de geschiktheid voor de dienst in termen van functie-eisen en derhalve ook medische eisen weer te geven. Een complicerende factor is dat het personeelsbestand niet homogeen is. Er zijn diverse personeelscategorieën: dienstplichtig personeel, beroepspersoneel met een dienstverband voor bepaalde tijd (BBT'ers) en beroepspersoneel met een dienstverband voor onbepaalde tijd (BOT'ers) ${ }^{1 /}$.

De procedure voor de indienstureding van dienstplichtigen wordt in de volgende paragraaf uitgebreid beschreven.

Voor de beroepsmilitairen verschilt de procedure per krijgsmachtonderdeel.

Bij de Koninklijke Landmacht worden BBT'ers geworven voor een functie voor een bepaalde periode (variërend tussen de één en zes jaar). De functies benaderen qua taakstelling het functioneren in oorlogstijd het meest. Naast de geschiktheid voor de dienst worden zij gekeurd voor een specifieke functie. De BOT'ers daarentegen, moeten multi-inzetbaar zijn in een functieroulatiesysteem. Dit systeem beslaat de algemene loopbaan voor de diverse militairen (officieren en onderofficieren). Hierbinnen is een reeks van functies opgenomen, die variëren van typische vredesfuncties tot typische oorlogsfuncties. Een verdere precisering vindt plaats door middel van individuele loopbaanpatronen. Door de grote verscheidenheid aan functies is de aanstellingskeuring van de BOT'ers gericht op de dienstgeschiktheid. Daamaast wordt om de vijf jaar periodiek geneeskundig onderzoek uitgevoerd om de dienstgeschiktheid te herbeoordelen.

De Koninklijke Luchtmacht (KLU) makkt geen onderscheid tussen BBT'ers en BOT'ers. Beide groepen moeten zowel voldoen aan de dienstgeschiktheid als aan de medische eisen van de 
uit te voeren functie. Voor de functie van vlieger moet de aspirant-werknemer een aanvullende keuring ondergaan.

'In tegenstelling tot de situatie bij de KL hanteert de Koninklijke Marine (KM) voor dienstplichtigen en aspirant beroepspersoneel grotendeels dezelfde richtlijnen. De keuring richt zich vooral op de dienstgroep waar de kandidaat voor opteert. Grofweg wordt onderscheid gemaakt tussen strenge keuringseisen voor aspirant mariniers en minder strenge eisen voor de overige dienstgroepen. Een uitzondering hierop vormen de onderzeedienst-, duiker-en vliegerkeuringen waarvoor speciale eisen gelden' ".

\subsubsection{Dienstplichtkeuringen}

De dienstplichtkeuring is een bijzondere aanstellingskeuring, die is vastgelegd in de Dienstplichtwet en een verplicht karakter heeft. Iedere Nederlandse man is in principe dienstplichtig, tenzij hij om medische redenen niet geschikt is om de militaire dienst te vervullen. Tijdens de dienstplichtkeuring vindı de bepaling van de lichamelijke en geestelijke geschiktheid van de keurling voor het functioneren in militaire dienst plaats. Voor dienstplichtigen geldt in het algemeen alleen deze basiseis. Pas als de dienstplichtige geschikı bevonden is, wordt een passende functie voor hem gezocht. Daarnaast worden voor speciale onderdelen extra keuringen verricht, zoals voor de Commando's, VN-uitgezondenen en de Koninklijke Marine.

Alvorens op de procedurele aspecten van de dienstplichtkeuring in te gaan, wordt eerst het ontstaan van de dienstplichtkeuring besproken.

\section{De geschiedenis van de dienstplichtkeuring}

De dienstplicht is ontstaan in de tijd van de Franse Revolutie aan het einde van de 18 de eeuw. In Nederland is de dienstplicht in 1814 in de Grondwet ingevoerd en in 1815 komt de eerste Militiewet tot stand ${ }^{20}$. Nadat iedereen gekeurd was, en degenen die wegens onvoldoende lengte of andere lichaamsgebreken ongeschikt voor de dienst waren verklaard, werd door loting bepaald wie diende op te komen. Geloot werd natuurlijk alleen wanneer het aantal beschikbaren de behoefte overtrof. Uit deze regeling vloeide de behoefte voort aan een keuringsreglement. Dit reglement bleef nog geruime tijd na de onafhankelijkheid van Nederland (van Frankrijk) van kracht. Hierin stond de minimale lengte aangegeven en 54 gebreken, die ongeschikt maken voor de militaire dienst, onder andere ontbering van het gezicht, verlies van het rechter oog, krankzinnigheid, razernij en zwakzinnigheid ". Daarna is het reglement meermalen bijgewerkt met het oog op de geldende medische inzichten. Momenteel worden de bepalingen van het Militair Keuringsreglement (MKR) van 1986 gehanteerd. Het principe is hetzelfde: iemand wordt geschikt verklaard tenzij hij lijdt aan enige ziekte of gebrek die staat vermeld in de lijst van aandoeningen en gebreken van het MKR.

Na de Tweede Wereldoorlog (WOII) dienden naast de geschiktheid ook de functiebeperkingen te worden aangegeven. Technische ontwikkelingen hadden geleid tot een vergaande mechanisatie en specialisatie. Hierdoor verdween de behoefte aan de 'eenheidssoldaat'. Functies en specialisaties werden gedifferentieerder is. Tevens moesten militairen op eenvoudige wijze en snel kunnen worden ingedeeld. Daarom werd na 1945 een indelingsmethode ingevoerd. 
Deze grove indelingsmethode is gericht op de 'algemene inzetbaarheid' van iedere militair ${ }^{22}$. De methode is afgeleid van het Canadese PULHEMS-systeem, een systeem dat in WOII is ontwikkeld door de Royal Canadian Medical Service en het Directorate of Personnel Selection. Het doel was 'to provide a finer functional assessment of the physical, mental and emotional capabilities of the individual in a form that could easily be interpreted by the Directorate of Personnel Selection' "2. Elke letter van het PULHEMS-systeem staat voor een bepaalde rubriek, die door de arts beoordeeld dient te worden: de P voor 'physique', de U voor 'upper', de L voor 'lower and locomotion', de H voor 'hearing and ears', de $\mathrm{E}$ voor 'eyes', de M voor 'mental capacity' en de S voor 'emotional stability'. Dit PULHEMS-systeem werd voor Nederland bewerkt door Eck en Kalten ${ }^{24}$. Sindsdien is dit zogenaamde ABOHZIS-systeem nauwelijks gewijzigd. Net zoals bij het PULHEMS-systeem, staat elke letter van de ABOHZIS voor een rubriek die door de arts beoordeeld wordt. De betekenis van de verschillende rubrieken wordt weergegeven in schema 1 .

Schema I: Betekenis wan de ABOHZIS-rubrieken

\section{ABOHZIS}

A

Algemeen fysieke toestand

O Onderste ledematen

Z Zien

$\mathrm{H} \quad$ Horen

I Intelligentie

S (Psychische) Stabiliteit

\section{betekenis}

lichamelijke ontwikkeling, de relatie tussen lengte en gewicht, geschiktheid tot het volgen van de militaire training vorm en functie van de bovenste extremiteiten en nek vorm en functie van de onderste extremiteiten en rug toestand en functie van gezichtsorgaan toestand en functie van gehoororgaan

In 1967 is het boek 'Aanwijzingen voor keurend artsen belast met militaire keuringen' uitgegeven ${ }^{25}$. Hierin wordt duidelijk omschreven hoe de keuring moet plaatsvinden, de wijze waarop gebreken en ziekten moeten worden geïnterpreteerd en vastgelegd en de wijze waarop een dienstplichtige volgens het ABOHZIS-systeem moet worden geclassificeerd ${ }^{18}$.

Dil Aanwijzingenboek is meerdere malen bijgewerkt.

\section{Procedures van de dienstplichtkeuring}

De dienstplichtige ondergaat de 'eerste' dienstplichtkeuring in het jaar waarin hij 18 jaar wordt. Daarna zijn nog herkeuringsmogelijkheden aanwezig. De keuring bestaat uit een anamnese, een lichamelijk onderzoek en een aanvullend onderzoek. Het anamneseformulier, dat de keurling thuis heeft ingevuld, wordt gebruikt als leidraad. Het lichamelijk onderzoek bestaat uit een algemeen oriënterend lichamelijk onderzoek, met het accent op het bewegingsapparaat en een inschatting van de psychische belastbaarheid. De volgende aanvullende onderzoeken worden verricht: 
het meten van de lengte en het bepalen van het gewicht

het meten van het gehoor (audiometrie)

het onderzoek van de urine

het vaststellen van de gezichtsscherpte

het vaststellen van het kleuronderscheidend vermogen

en afhankelijk van de gezichtsscherpte, het stereoscopisch zien.

De lichamelijke en geestelijke geschiktheid van de keurling wordt vastgelegd aan de hand van:

1. de keuringsuitslag: geschikt, tijdelijk of voorgoed ongeschikt.

Bij een tijdelijke ongeschiktheid krijgt de keurling, na een vooraf vastgestelde periode (van maximaal één jaar), een nieuwe keuring.

2. ziekten en gebreken volgens de negende versie van de International statistical

Classification of Diseases, injuries and causes of death (ICD-code) ${ }^{\text {th }}$,

3. een reden van alkeuring volgens de codering van het Militair Keuringsreglement: een zogenaamde MKR-code.

Als een keurling ongeschikt wordt bevonden, moet, naast de notering van de ICD-codes, de afkeuringsreden worden vastgelegd met een MKR-code. Deze correspondeert met een aandoening die volgens het MKR tot afkeuring leidt. Bij enkele ziekten en gebreken wordt men afgekeurd als de ziekte of het gebrek alleen al wordt vastgesteld en herstel binnen korte tijd niet mogelijk wordt geacht. Bij de andere ziekten en gebreken is de ernst van de ziekte en het gebrek bepalend voor het al dan niet geschikt zijn. Dit betekent dat iemand met een bepaalde aandoening geschikt kan worden verklaard, terwijl iemand anders met dezelfde aandoening ongeschikt kan worden bevonden $:$. Verder kan een keurling ongeschikt worden verklaard als de afzonderlijk geconstateerde aandoeningen geen afkeuringsreden zijn, maar tezamen wel tot afkeuring leiden (artikel 4.1.b. van de Dienstplichtwet).

4. De ABOHZIS-classificatie bij de geschikten (ten behoeve van de funcrie-indeling). Als een persoon geschikt wordt verklaard, moet worden ingeschat welke inspanningen tijdens en na de opleiding van die persoon verwacht kunnen worden ". De keurend arts dient de $\mathrm{ABOHZIS}$-classificatie van elke geschiktverklaarde op te maken. De mate van geschiktheid wordt voor iedere $A B O H Z I S$-rubriek afzonderlijk vastgesteld. De waardering geschiedt door het toekennen van het klassecijfer 1,2 of 3 voor iedere rubriek ${ }^{25}$.

\section{Organisatie en onvang van de dienstplichtkeuring}

De dienstplichtkeuringen worden verricht door een aantal, door het land verspreide indelingsraden en één centrale herkeuringsraad (CHR). De indelingsiaden verrichten đe zogenaamde eerste dienstplichtkeuringen en een aantal herkeuringen. De CHR verzorgt uitsluitend herkeuringen.

Bij elke indelingsraad behoort een keuringscommissie ( $\mathrm{KC}$ ). Deze bestaat uit een Voorzitter Keuringscommissie (VKC) en een aantal leden (keurend artsen), waaraan paramedische en administratieve medewerkers zijn toegevoegd. De medewerkers van de KC van de indelingsraden ressorteren functioneel onder het hoofd van de Afdeling Geneeskundige Aangelegen- 
heden Dienstplichtzaken van de Directie Dienstplichtzaken. Het hoofd van de Afdeling Geneeskundige Aangelegenheden is tevens hoofd van de CHR.

Jaarlijks zijn ongeveer 100.000 keuringen verricht. Er zijn echter schommelingen. In 1993 zijn in het kader van de eerste dienstplichtkeuringen 86.362 personen gekeurd, waarvan $35 \%$ is afgekeurd. Tevens zijn 15.065 herkeuringen verricht, waarbij $57 \%$ is afgekeurd ${ }^{28}$. In 1994 zijn 66.631 eerste dienstplichtkeuringen verricht, waarvan ook nagenoeg $35 \%$ is afgekeurd. Omdat volgens de Dienstplichtwet alle Nederlandse mannen gekeurd moeten worden, vallen onder de afgekeurden ook personen die zijn opgenomen in een psychiatrische inrichting, een doofstommen- of blindeninstituut of een sanatorium tot verpleging van tuberculosepatiënten. Zij hoeven niet lijfelijk te worden afgekeurd. Een schriftelijk geneeskundige verklaring van het hoold van de desbetreffende inrichting of het instituut geldt als bewijs voor het bestaan van de afkeuringsreden.

Ter ondersteuning bij de bepaling van de geschiktheid voor de vervulling van functies als (dienstplichtig) militair worden uit de keuring voortvlociende gegevens niet alleen in dossiers vastgelegd. Zij worden vanaf 1978 ook bijgehouden in het medische informatiesysteem KGO (Keuringen en Geneeskundige Onderzoeken). Met behulp van dit systeem kan inzicht worden verkregen in de belangrijkste afkeuringsredenen. Deze redenen worden met behulp van MKRcodes en bijbehorende ICD-codes vastgelegd. De afkeuringsredenen (in ICD-codes) van dienstplichtigen die in 1994 zijn gekeurd, staan in tabel l vermeld.

Tabel 1:

Afkewringsredenen van de eerste dienstplichikeuring in 1994

ICD-code

aantal

$\%$ van de populatie

000-139 infectieziekten en parasitaire ziekten

34

0,1

140-239 nieuwvormingen

157

0,2

$240-279$

endocrien, voedings- en stofwisselings-

1324

2,1

280-289 ziekten van bloed en bloedbereidende organen

98

0,2

290-319

psychische stoornissen

3671

5,7

320-389 ziekten van zenuwstelsel en zintuigen

6199

9,6

390-459 ziekten van de bloedsomloop

102

0,2

460-519 ziekten van de ademhalingsorganen

3077

4,8

510-579 ziekten van de spijsvertering

209

0,3

580-629 ziekten van de urogenitaalorganen

116

0,2

680-709 ziekten van huid en onderhuids bindweefsel

213

0,3

710-739 ziekten van spieren, beenderen en bindweefsel

4212

6,5

740-759

aangeboren afwijkingen

1075

1,7

$760-779$

aandoeningen ontstaan in perinatale periode

0

0,0

$780-799$

symptomen en onvolledig omschreven ziektebeelden

587

0,9

800-999

ongevalsletseis en vergiftigen

1104

1,7

000-999

totaal aantal afwijkingen

22178

34,5

\section{Keuren is Mensenwerk}


Van de keuringen van 1994 zijn 22.178 afkeuringsredenen nader gespecificeerd. Bij een klein percentage, namelijk $0,5 \%$, is de reden van afkeuring niet direct af te leiden uit de gegevens van het registratiesysteem. De meeste keurlingen zijn afgekeurd wegens ziekten van het zenuwstelsel en zintuigen; daaronder vallen aandoeningen van het oog en het oor. Daarnaast zijn ziekten van spieren, beenderen en bindweefsel belangrijke redenen. Hierbij zijn chondromalacie van de patella en slappe ligamenten de belangrijkste oorzaken. Ook psychische stoornissen en ziekten van de ademhaling, zoals astma, zijn betekenisvolle afkeuringsredenen.

Het is geen eenvoudige zaak te achterhalen in hoeverre deze afkeuringspercentages en afkeuringsredenen ook voor andere landen gelden. In de literatuur zijn weinig bruikbare gegevens te vinden ${ }^{20}$. Informatie van ambassades van Europese landen waar ook de dienstplicht geldt, levert slechts een globale indruk. De verschillende afkeuringspercentages zijn als volgt: tijdens de dienstplichtkeuring wordt in Duitsland 30\% afgekeurd, in Frankrijk, België en Zwitserland $17 \%$ en in Zweden 15\%. Alhoewel deze percentages lager zijn dan in Nederland, moet de interpretatie van deze gegevens behocdzaam geschieden, omdat de exacte procedures niet bekend zijn. Zo is onder andere niet duidelijk of de percentages het percentage afkeuringen bij de eerste dienstplichtkeuringen representeren of de afkeuringspercentages bij de eerste keuringen én herkeuringen vóór opkomst.

Ook is niet veel bekend over de (minimale) keuringseisen, zoals de minimale en maximale toelaatbare lengte, de grenzen van obesitas en myopie.

Dit bevestigl het vordeel van Stadt " die aangeeft dat vergelijking van goed- en afkeuringspercentages van andere landen zinloos is, 'zolang men niet van eenzelfde keuringssysteem uitguat met dezelfde normen en dezelfde mate van gebruik van objectieve criteria'.

\subsubsection{Onderscheid tussen keuringen in de burgermaatschappij en de krijgsmacht}

Hoewel in de burgermaatschappij net als in de krijgsmacht aanstellingskeuringen worden verricht, ijin verischillen aantoonbaar (schema 2). 
burger militairen

beroeps

niet verplicht,

zelfselectie

MKR, ABOHZIS, Aanwijzingenboek en eigen richtlijnen

dienstgeschiktheid, functiegericht

goedkeuring is gewenst

goedkeuringswens van

betrokkene afkeuring heeft minder ernstige maatschappelijke gevolgen dienstplichtigen

Dienstplichtwet verplicht, geen zelfselectie

MKR, ABOHZIS en Aanwijzingenboek

dienstgeschiktheid goedkeuring niet altijd gewenst afkeuring heeft minder ernstige maatschappelijke gevolgen voor het individu

\section{Regelingen en procedures van de keuring}

De juridische positie van de keurling is afhankelijk van het soort keuring. Het ondergaan van de dienstplichtkeuring is een wettelijke verplichting. Bij alle andere aanstellingskeuringen is de kandidaat in principe vrij om zelf te bepalen of hij wel of niet meedoet aan de selectieprocedure. Met andere woorden, er is sprakt van zelfselectie. Echter, de consequentie van het niet gekeurd willen worden, heeft vanzelf een afwijzing voor de baan tot gevolg. De meeste aanstellingskeuringen zijn privaatrechtelijk verplicht of staan in CAO's vermeld. Mede door de mogelijkheid van zelfselectie zijn tussen de diverse keuringen verschillen aanwezig. Bij de dienstplichtkeuring wordt $35 \%$ afgekeurd. Bij de keuringen voor beroepsmilitairen is dit percentage hoger. Uit interne bronnen is vernomen dat bij de aanname van beroepsmilitairen van de KL $40 \%$ de psychologische selectie doorstaat. Daarvan wordt $10 \%$ tot $12 \%$ alsnog om medische redenen ongeschikt verklaard. In totaal wordt, na de psychologische selectie en medische keuring, 52\% niet aangenomen als beroepsmilitair. Het merendeel (meer dan $80 \%$ ) dat aan deze procedure deelneemt, bestaat uit personen die solliciteren naar een baan als beroepsmilitair voor bepaalde tijd. Bij de keuringen voor burgers wordt slechts $5 \%$ afgekeurd. Bij de aanstellingskeuringen in de matschappij is er, naast zelfselectie, een onbekend percentage personen dat zich op advies van de keurend arts terugtrekt uit het sollicitatieproces, zonder dat daarbij een formele afkeuring plaatsvindt ${ }^{4}$. Deze mogelijkheid is bij dienst- 
plichtkeuringen niet aanwezig.

De belangrijkste oorzaak is het verschil in 'selectie'-mechanisme. Dienstplichtigen zijn in principe ahijd geschikt., tenzij zij niet voldoen aan de geschiktheidseisen voor de dienst. Pas daarna wordt voor ieder individu een passende functie gezocht.

Mer uitzondering van de keuring voor de BOT'ers van de KL, zijn de keuringen van beroepsmilitairen, naast de bepaling van de dienstgeschiktheid, functiegroepspecifiek. De eisen voor een beroepsmilitair zijn hoger dan die voor een dienstplichtige.

De afkeuringspercentages binnen Defensie zijn hoger dan bij aanstellingskeuringen in de burgermaatschappij omdat de militaire keuring een onderdeel van het selectieproces is. Bij aanstellingskeuringen voor burgers dient de keuring daarentegen als sluitstuk van de sollicitatieprocedure. Het afkeuringspercentage verschilt daarnaast ook omdat de lichamelijke eisen voor beroepsmilitairen en dienstplichtigen over het algemeen strenger zijn dan voor burgerfuncties.

Een ander belangrijk verschil is de manier warop het doel en de procedure van de keuring is vastgelegd. De aanstellingskeuringen in de burgermaatschappij zijn geconditioneerd zelfregulerend. Richtlijnen omtrent zowel functie als medische eisen ontbreken veelal. Dit geldt voor militaire keuringen ten aanzien van de functie-eisen. Daarentegen zijn de medische cisen voor de dienstgeschiktheid voor de militairen in het MKR vastgelegd. Met het ABOHZIS-classificatiesysteem en het boek 'Aanwijzingen voor keurend artsen belast met militaire keuringen' zijn de eisen voor de lichamelijke en geestelijke geschiktheid voor de dienst uitgewerkt. Echter, het functiespecifieke gedeelte van de beroepskeuring is tot nu toe noch in hel MKR, noch in het Aanwijzingenboek opgenomen. Soms zijn specifieke eisen in aparte richtlijnen beschreven.

\section{Gevolgen van een goed- of afkeuring}

Een goed- of afkeuring heeft bij de verschillende keuringen een andere waarde voor de keurling. Zo heeft een goedkeuring bij een aanstellingskeuring to gevolg dat de keurling de begeerde functie kan gaan uitoefenen. Een geschiktheidsverklaring voor de militaire dienst betekent dat de dienstplichtige zijn plicht moet vervullen, of hij dat nu wil of niet. Het vervullen van de dienstplicht kan voor het individu maatschappelijke gevolgen hebben. Naar deze gevolgen is onderzoek verricht. Onder ex-dienstplichtigen en leeftijdgenoten die niet in dienst zijn geweest, is een telefonische enquête gehouden. De maatschappelijke voor- en nadelen zijn daarbij vastgesteld aan de hand van het huidige inkomen en het subjectieve oordeel daar over van de geënquêteerde zelf. Op basis van de resultaten van deze enquêtc zijn gecn maatschappelijke nadelen vastgesteld. Conclusies zijn dat ex-dienstplichtigen voor een groot deel van mening zijn dat zij voordeel hebben gehad door het vervullen van de dienstplicht. Aan het huidige inkomen kan dat echter niet worden afgelezen ". Een ander onder soek ". laat wel individuele maatschappelijke gevolgen zien. In dit onderzoek zijn de gevolgen van de militaire dienstplicht niet alleen geinventariseerd bij dienstplichtigen en vrijgestelden, maar ook bij dienstplichtigen met vervangende dienst. Volgens dit onderzoek is er een onrechtvaardige verdeling van de dienstplichtlasten. Een minderheid, bestaande uit lager en middelbaar opgeleide jongeren, moet de negatieve gevolgen van de militaire dienst dragen. Het dienstplichtsysteem biedt daarentegen kansen aan hen die door hun opleiding al tot de kansrijken behoren. De hoger opgeleiden worden veelal buitengewoon dienstplichtig verklaard, waardoor ze niet in 
dienst hoeven of worden positief gestimuleerd in hun maatschappelijke loopbaan door de vervangende dienstplicht.

Ook een afkeuring kan maatschappelijke gevolgen voor de keurling hebben. Het is niet bekend welke deze zijn en welke financiële gevolgen ze kumnen hebben.

Waarschijnlijk heeft een afkeuring bij aanstellingskeuringen in de burgermaatschappij zwaardere consequenties voor de verdere carrière dan een afkeuring voor een beroepsmilitair of dienstplichtig militair. Omdat de medische eisen bij de krijgsmacht over het algemeen strenger zijn, komt een alkeuring voor een functie bij de krijgsmacht vaker voor dan voor een functie in de burgermaatschappij. Als een burger ooit voor een bepaalde 'burgerfunctie' is afgekeurd en in die richting verder blijft zoeken, dan zal die persoon moeten beargumenteren waarom hij/zij ondanks de afkeuring in het verleden, nu wel geschikt is voor de functie.

\section{(Dis)simulatieproblematiek}

On de keuringsuitslag te beinvloeden kan de keurling simuleren of dissimuleren. Met simulatie wordt bedoeld dat iemand zich ongezonder voordoet dan hij of zij in werkelijkheid is. Bij dissimulatie doet men zich gezonder voor. Er is weinig bekend over de simulatieproblematiek. Wel wordt aangegeven dat de kans op simulatie groter is als de ziekte vager is, omdat ziektegedrag dan belangrijker wordt ${ }^{33}$. Voûte ${ }^{34}$ spreekı nier van simulatie maar van bedrog. Volgens hem is de kans op bedrog bij de anamnese groter dan bij het lichamelijk onderzoek, echter $100 \%$ bedrog zou niet mogelijk zijn.

Bij dienstplichtkeuringen komen waarschijnlijk meer simulanten dan dissimulanten voor. Dissimulatie zal bij de dienstplichtkeuring alleen voorkomen bij jongens die graag in dienst willen. Een voorbeeld: iemand die bij de Commando's of de bij de Mariniers wil, weet das hij niets mag mankeren. Bij keuringen voor beroepsmilitairen komt vermoedelijk meer dissimulatie dan simulatie voor.

In welke mate (dis)simulatie voorkomt, is niet vast te stellen: een 'goede' simulant of dissimulant is per delinitie niet te achterhalen. On (dis)simulatie zoveel mogelijk te voorkomen, zijn er wettelijke bepalingen bij bedrog en verzwijging. Volgens Voûte " 'denken arisen en juristen rotaal anders over verzwijging en bedrog. Voor de arts ligt bedrog ergens op de schaal van $100 \%$ van vooropgezul bedrog tol $10 \%$ van kleine verzwijging. Voor de jurisı geldt een 'entweder oder'. Voor hem is er sprake van bedrog of geen bedrog: een tussenoplossing is niet mogelijk. In het Nieuw Burgerlijk Wetboek valt (dis)simulatie onder bedrog. Volgens artikel 3.2.10 lid 3 is er sprake van bedrog 'wanneer iemand een ander tot het verrichten van een bepaalde rechtshandeling bewergt door enig opzettelijk daartoe gedane onjuiste mededeling, door het opzettelijk daartoe verzwijgen van enig feit dat de verzwijger verplicht was te melden of door een andere kunstgrcep.' Bij bedrog kan de overeenkomst nietig worden verklaard. Speciaal voor dienstplichtkeuringen staat in artikel 14 van de Dienstplichtwet aangegeven dat, als een gegrond vermoeden bestaat dat iemand als gevolg van bedrog voorgoed ongeschikt is bevonden, de uitspraak door de minister vervallen wordt verklaard. De persoon in kwestie wordt dan geplaatst in verhouding tot de dienstplicht waarin hij zou hebben verkeerd, indien hij niet volledig ongeschikı was verklaard. Eind vijftiger jaren is dit artikel toe-

\section{Keuren is Mensenwerk}


gepast omdat een diensiplichtige bij de keuring de indruk wekte zwakzinnig te zijn, terwijl later is gebleken dat hij de lagere school en de avondlandbouwschool als respectievelijk middelmatige en goede leerling heeft doorlopen. Op basis van deze fraude is de keuringsuitspraak 'ongeschikt' terecht vervallen ".

\subsubsection{Nieuwe ontwikkelingen binnen de krijgsmacht}

Het keuringsapparaat is onderwerp van kritiek. Eén van de redenen daarvoor is dat het ABOHZIS-systeem onvoldoende specifiek is omdat het niet gericht is op de uit te octenen functie. Iemand met een $\mathrm{O} 3 \mathrm{kan}$ een scheve rug of krommc teen hebben. De functics waar beide personen met een $\mathrm{O} 3$ niet geschikt voor zijn, kunnen echter verschillen.

Er is ook kritiek op het MKR. De richtlijnen die hierin zijn beschreven, zijn verouderd. Het MKR is sinds 1968 nauwelijks gewijzigd, terwijl de medische inzichten wel zijn veranderd. Het MKR is gericht op de ongeschiktheid van de persoon; iemand is geschikt zolang ongeschiktheid niet kan worden aangetoond. Tegenwoordig vindt men dat de geschiktheid van de persoon het uitgangspunt moet zijn. Daarnaast leiden, volgens het MKR, bepaalde ziekten tot afkeuring, ongeacht de status praesens. Zo kan men bijvoorbeeld vraagtekens zetten bij de afkeuring van een persoon bij wie op zeer jeugdige leeftijd een tumor operatief totaal is verwijderd en die al 10 jaar als genezen wordt beschouwd.

De tekortkomingen van het keuringsapparaat worden binnen het Ministerie van Defensie erkend. Verschillende stuur- en werkgroepen zijn in het leven geroepen met als doel het systeem te verbeteren. Binnen de $\mathrm{KL}$ zijn diverse pogingen gedaan om het keuringsapparaat te verbeteren. De belangrijkste worden hieronder kort vermeld.

\section{Functiegram-somagram}

Sinds de jaren ' 80 is men bezig een systeem te ontwikkelen waarbij de medische eisen zijn afgestemd op de functie-eisen. Rond 1980 is een werkgroep belast met de taak een systeem te ontwikkelen waarbij de belasting en de belastbaarheid zijn afgestemd ${ }^{22}$. Per functie dienen functie-eisen te worden geformuleerd, waaraan de militair minimaal moet volduen. Deze eisen worden op systematische wijze gegroepeerd waardoor per functie het model functiegram ontstaat. Daarnaast moeten de belastbaarheid, de fysieke en psychische basiscigenschappen van de persoon worden aangegeven in het model somagram. 'Het somagram is als het ware een spiegelbeeld van het functiegram' 's. Het doel van dit systeem is het verschalfen van een eenvoudig en praktisch raamwerk, waarbinnen de eisen van luncties tegenover een daarop aansluitend medisch beperkingsprofiel van het personeel zichtbaar wordt gemaakt.

De werkgroep heeft zijn taak niet kunnen volbrengen ondat de profielen waaraan een militair moet voldoen te talrijk waren. Dit leverde een onoplosbaar probleem op.

Nieuwe pogingen zijn ondernumen. In 1993 is een soortgelijke werkgroep 'Somagram' opgericht, die opnieuw in november 1993 als ondersteunende werkgroep voor de stuurgroep 'Functiegram-Somagram' (FuSo) is ingesteld. De werkgroep heeft een lijst met zogenaamde kritische functie-aspecten geselecteerd, die relevant zijn voor militaire functies en meetbaar 
zijn. Naast tientallen medische aspecten zijn vijf aspecten opgenomen waarbij de fysieke belastbaarheid een rol speelt. Deze worden aangeduid als de 'vijf criteriumtaken', te weten: de algemene conditie, lopen met bepakking, herhaald tillen, graven en dragen. Ten aanzien van de 4 laatst genoemde taken kan men een viertal normen hanteren: $1=$ hoge eis, $2=$ gemiddelde eis, $3=$ geen dagelijkse eis, alleen in geval van nood, $4=$ geen eis. De norm voor de algemene conditie loopt op van $4=$ basiseis conditieproef $\mathrm{KL}$, naar hogere eisen 3, 2, 1 die onathankelijk zijn van leeftijd en geslacht.

Deze methodiek zal de huidige VFO-test (VFO = vaststellen fysieke opleidbaarheid) gaan vervangen. De VFO-test, waarbij als eerste belastbaarheidsgegevens zijn toegevoegd aan de medische keuringsgegevens, spreekt zich alleen uit over de belastbaarheid op het niveau van de algemene conditie ". De vijf criteriumtaken zijn daarentegen gericht op de fysieke eisen die bij de functie-uitvoering van de militair van belang zijn.

\section{Militaire keuringen}

Op beleidsniveau is het werkverband 'Militaire keuringen' ingesteld, dat zich bezighoudt met de herziening van de verouderde regelgeving van militaire keuringen. Voorstellen ter verbetering zullen belangrijke consequenties hebben voor het MKR en de aanvulling 'Aanwijzingen voor artsen belast met militaire keuringen'. Bij de herziening zal het MKR niet uitgaan van de ongeschiktheid maar van de geschiktheid voor een militaire functie(groep) en de opleiding daartoe. Uitoefening van de functie mag geen schade berokkenen aan de gezondheid of veiligheid van betrokkene of aan derden. In deze filosofie is geen plaats voor de huidige lijst van aandoeningen en gebreken, want deze gaat uit van ongeschiktheid. Wel kunnen bevindingen leiden tot beperkingen in het uitoefenen van de functie. Het beschikken over functie-eisen is dan essentieel. Bij deze beoordeling zal gebruik worden gemaakt van een lijst van beperkingen in het functioneren. Deze lijst is in ontwikkeling en gebaseerd op de International Classification of Impairment, Disability and Handicaps (ICIDH) van de World Health Organisation "t.

\section{Indelingseisen $K L$}

Om op korte termijn de indelingseisen te actualiseren, is de werkgroep 'Indelingseisen KL' (WIKL) in het leven geroepen. De hoogste prioriteit heeft momenteel het bijstellen van de medisch-fysieke indelingseisen voor BOT-personeel ". Om pragmatische redenen ligt de basis voor de indelingseisen in het ABOHZIS-classificatiesysteem.

De nieuwe ontwikkelingen hebben allen tot doel de militaire keuring te verbeteren. Ook het onderhavige onderzoek heeft dit als doelstelling. Derhalve zal in de volgende paragraal eerst worden nagegaan welke mogelijkheden aanwezig zijn om op basis van wetenschappelijk onderzoek de kwaliteit van de militaire keuringen te analyseren. 


\subsection{De kwaliteit van keuringen}

\subsubsection{Inleiding}

De aanstellingskeuring kan worden gezien als een diagnostische test, waaruit een positieve dan wel een negatieve testuitslag voorivloeit. Met een positieve testuitslag wordt in dit geval een afkeuring bedoeld. De gebruikte testen zijn positief in die zin, dat afwijkingen zijn gevonden waardoor de keurling niet geschikt wordt geacht voor de militaire dienst. Een negatieve testuitslag betekent een goedkeuring.

Overeenkomstig met de kwaliteitsmeting van diagnostische testen, kan de kwaliteit van de militaire keuring worden geanalyseerd aan de hand van de reproduceerbaarheid en de validiteit.

\subsubsection{Reproduceerbaarheid}

Een keuring dient tot reproduceerbare uitslagen te leiden. De reproduceerbaarheid van een keuring geeft de mate aan waarin de keuring eenzelfde uitslag oplevert indien deze op twee of meer verschillende momenten plaatsvindt en door één of meer artsen wordt verricht. De reproduceerbaarheid wordt beïnvloed door de biologische variabiliteit van de onderzochte personen en door waarnemingsfouten, die veroorzaakt kunnen worden door het gebruikte meetinstrument en/of de keurend artsen "s.

Van biologische variabiliteit is sprake als het gemeten kenmerk van een persoon in de tijd varieert. Bij toevallige biologische variatie is geen duidelijk patroon herkenbaar, zoals bijvoorbeeld bij de bloeddruk. Deze variatie kan men minimaliseren door de gemiddelde waarde van meerdere metingen te gebruiken. Bij systematische biologische variatie fluctueert het gemoten kenmerk volgens een vast patroon en dit kan worden geminimalisecrd als het vaste patroon herkenbaar is. Een voorbeeld is lichaamslengte. Deze is aan het begin van de dag hoger dan aan het eind van de dag. Deze variatie kan worden gecorrigeerd door op een vast tijdstip te meten.

Ook bij meetfouten ten gevolge van het gebruikte meetinstrument is een onderscheid te maken tussen systematische en toevallige variatie. Alleen de toevallige variatie gaat ten koste van de reproduceerbaarheid, de systematische meetfouten niet.

Als de biologische variabiliteit van de keurling en de meetinstrumenten onder controle zijn, zou men kunnen verwachten dat een herhaalde toepassing van de keuring leidt tot cen consistente beslissing.

Inconsistentie kan echter veroorzaakt worden door de keurend artsen. Die kan worden opgespoord door de mate van de intra-dokter-en inter-doktervariatie te onderzoeken.

Mut de intta-doktervariatie wordt bekeken of ten arts stceds tot dezelfde bevindingen komt. lion keurling wordt dan ten minste rwee kicr door de'zitde arts onderzocht. Voorwaarde is dat de tijd tussen de keuringen zodanig is gekozen dat de arts de bevindingen van voorgaande 
keuringen niet meer kan traceren. Daarom mag de tijd tussen de opeenvolgende keuringen niet te kort zijn. De periode tussen de keuringen mag ook niet te lang zijn omdat de biologische variabiliteit van de gekeurde persoon de bevindingen van de arts terech kan beinvloeden. De inter-doktervariatie laat de verschillen in beoordeling zien tussen minimaal twee artsen die beiden dezelfde personen keuren.

Specifiek voor dienstplichtkeuringen geldt dat zij op verschillende locaties, namelijk op de zogenaamde indelingsraden, worden verricht. Dat betekent dat ook variatie aanwezig kan zijn op de indelingsraden zelf, met ander woorden variatie tussen de artsen op eenzelfde indelingsraad oftewel intra-raadvariatie.

Ook de gemiddelde keuringsuitslagen tussen de raden kunnen verschillen. Bij inter-raadvariatie worden de bevindingen van alle artsen van een bepaalde raad vergeleken mel de bevindingen van een andere raad.

\section{Kappa}

Een maat om de consist'ntie van één of meer artsen te kwantificeren is Cohen's kappa. Dit is een maat voor inter- $\mathrm{c}$ intra-beoordelaarsovereenstemming die de feitelijke overeenstemming als proportic van de potentic̈le overeenstemming weergeeft, na correctie voor de toevalsovereenstemming ${ }^{30}$.

Met een groepskappa kan de overeenstemning tussicn meerdere beoordelaars worden berckend. De groepskappa is een maat voor paarsgewijze overeenstemming in cen groep beoordelaars ${ }^{\text {in }}$.

De groepskappa wordt als volgt berekend: Kappa $=\left(\bar{p}_{c} \cdot \bar{p}_{e}\right) /\left(1-\overline{p_{e}}\right)$

Hierin is $\overline{p_{0}}$ respectievelijk $\bar{p}_{i^{\prime}}$ de wargenomen (observed) en de toevallige (chance expected) overeenstemming tussen twee beoordelaars, gemiddeld over alle mogelijke tweetallen beoordelaars. In deze groepskappa wordt de gemiddelde overeenstemming gecorrigeerd voor toevallig optredende overeenstemming.

De kappa varieert tussen 0 en 1 . Hoe hoger de kappa, hoe hoger de overeenstemming. Ondanks het feit dat de kappa rekening houdt met toevallige overeenstemming, heeft deze maat enige beperkingen. De kappa is namelijk afhankelijk van het aantal beoordelingscategorieën. In het algemeen geldt dat meer categoricün tot kleinere kappawaarden leiden. Daamaast is de kappa afhankelijk van de (verwachte) prevalentie van elk van de mogelijke beoordelingsuitkomsten ${ }^{36}$. De interpretatie van de warden is derhalve niet eenduidig ${ }^{12}$. De volgende indeling wordt gebruikt:

$<0.40 \quad$ : geringe overeenstemming

$0.40-0.60$ : redelijke overeenstemming

$0.60-0.80:$ goede overeenstemming

$>0.80:$ voortreffelijke overeenstemming ${ }^{12,41}$. 


\subsubsection{Validiteit}

De validiteit van de keuring geeft informatie over de mate waarin met een keuring de geschiktheid van een kandidaat juist wordt beoordeeld.

Reproduceerbaarheid en validiteit zijn afhankelijk van elkaar. Reproduceerbaarheid is een voorwaarde om te komen tot valide keuringen. Validiteit is de belangrijkste maatstaf om de kwaliteit van de test te meten.

Twee gangbare maten om de validiteit te kwantificeren zijn de sensitiviteit en de specificiteit. De sensitiviteit geeft aan welk percentage van de personen dat in feite ongeschikt is voor de militaire dienst (terecht) als ongeschikt wordt geclassificeerd. De specificiteit geeft aan welk percentage van de groep personen dat in feite geschikt is voor militaire dienst (terecht) als geschikt wordt geclassificeerd.

Op het moment van de keuring weet men niet wie terecht of onterecht wordt goedgekeurd en afgekeurd. Daarom is men geïnteresseerd in de voorspellende waarde oftewel predictieve waarde.

De kans dat een persoon met een negatieve testuitslag (goedgekeurd) tijdens het vervullen van de dienstplicht ook inderdaad geschikt blijkt te zijn, wordt de negatieve voorspellende waarde genoemd.

De positieve voorspellende waarde kan in de\% situatie niet worden berekend, omdat degenen met een positieve testuitslag (en zijn afgekeurd) niet in dienst komen. De daadwerkelijke geschiktheid van de afgekeurden blijkt in praktijk niet vastgesteld te kunnen worden.

Sensitiviteit, specificiteit en prevalentie (het voorkomen van aandoeningen) bepalen de voorspellende waarde van de test. Een grotere sensitiviteit gaat gepaard met een grotere positieve voorspellende waarde en een grotere negatieve voorspellende waarde. Hetzelfde geldt, bij gelijkblijvende sensitiviteit, voor een grotere specificiteit ${ }^{\text {"v. }}$. De prevalentie van ziekten die leiden tot afkeuring in de onderzochte populatie, beïnvloedt de voorspellende waarde als volgt: een geringere prevalentie leidt in het algemeen tot een geringere positieve voorspellende waarde en een grotere negatieve voorspellende waarde ${ }^{36,3 \%}$. 
In de onderstaande tabel 2 is de relatie weergegeven tussen de uitslagen van de keuringen en de uiteindelijke geschiktheid. De relatie tussen de verschillende items is duidelijk zichtbaar.

\begin{tabular}{|c|c|c|c|}
\hline \multirow[b]{3}{*}{ Positief (afgekeurd) } & GESCHIKTHEID & & \multirow[b]{3}{*}{$\begin{array}{l}\text { positieve } \\
\text { voorspellende waarde }\end{array}$} \\
\hline & ongeschikt & geschikt & \\
\hline & $\begin{array}{l}\text { terecht-positief } \\
\text { (a) }\end{array}$ & $\begin{array}{l}\text { fout-positief } \\
\text { (b) }\end{array}$ & \\
\hline \multicolumn{4}{|l|}{ TESTUITSLAG } \\
\hline \multirow{3}{*}{ Negatief (goedgekeurd) } & (c) & (d) & negatieve \\
\hline & fout-negatief & terecht-negatief & voorspellende waarde \\
\hline & sensitiviteit & specificiteit & \\
\hline
\end{tabular}

\section{formule:}

sensitiviteit:

$$
\begin{array}{ll}
\text { Se } & =a / a+c \\
\text { Sp } & =d / b+d \\
p & =a+c / a+b+c+d \\
W W_{+} & =a / a+b \\
W W- & =d / c+d
\end{array}
$$$$
\text { specificiteit: }
$$$$
\text { prevalentie: }
$$$$
\text { positieve voorspellende waarde: }
$$$$
\text { negatieve voorspellende waarde: }
$$

Bij een keuring wordt beoordeeld of de functie kan worden uitgevoerd zonder gevaar voor gezondheid of veiligheid voor de persoon of derden. De aanwezigheid van de aandoeningen wordt nagegaan.

Daarnaast kan de arts beoordelen of risicofacioren bij de keurling aanwezig zijn. De mogelijkheid bestaat dat een persoon met een bepaalde risicofactor bij uitvoering van de werkzaamheden de functie niet meer kan uitvoeren, omdat zich een aandoening heeft gemanifesteerd. Risicofactoren kunnen op deze wijze worden beschouwd als predictoren van de toekomstige gezondheid. Dit risico kan worden uitgedrukt in een relatief risico (RR). Dit geeft de kans weer op het krijgen van een aandoening bij personen met een bepaalde risico-factor ten opzichte van personen waarbij deze risicofactor niet aanwezig is.

De keuze welke risico's men wel of niet meeneemt bij de beoordeling en hoe groot deze moeten zijn, is onderwerp van discussie. Volgens De Kort ${ }^{12}$ zou men kunnen overwegen om aan de hand van risicolactoren te selecteren indien als grenswaarde wordt aangehouden dat het relatieve risico van de factor in ieder geval niet minder is dan 2.5 en liefst groter is dan 5 . Een licht verhoogd risico (dat wil zeggen bij een RR tussen de 1.5 en 2.5) heeft te weinig consequenties om screening in overweging te nemen. Bij een sterk verhoogd risico (met een relatief risico groter dan 5) kan selectie worden overwogen. Echter, het is niet goed om bij deze afweging alleen af te gaan op de hoogte van relatieve risico's. Ook andere argumenten zoais de prevalentie van de factor, de ernst van de consequentie, waaronder het aantal onterecht afgekeurden, dienen te worden meegenomen. 


\subsubsection{Praktische (on)mogelijkheden}

Wat zijn nu de mogelijkheden om de kwaliteit van de militaire (dienstplicht)keuring na te gaan?

Niet alle facetten van de reproduceerbaarheid zijn relevant om te onderzoeken. De biologische variabiliteit van de keurling is een niet-beïnvloedbaar gegeven en derhalve geen thema voor verder onderzoek naar de kwaliteit van de militaire keuring. Om fouten bij meetinstrumenten te achterhalen moet uitgebreid onderzoek worden gedaan naar de inhoud van de specifieke keuringsonderdelen en de daarbij gehanteerde methoden. In eerste instantie gaat het echter niet om hoe gekeurd wordt, maar om de uiteindelijke uitspraak door de keurend arts. Hij/zij geeft de uitslag geschikt of ongeschikt. Aan de hand van aanwezige gegevens kan worden bepaald of variatie tussen de artsen wat betreft de keuringsuitspraak aanwezig is. Of deze variatie veroorzaakt wordt door een te geringe overeenstemming tussen de artsen kan met behulp van een experiment worden nagegaan. Het meest ideaal is als alle artsen dezelfde keurlingen beoordelen op geschiktheid voor de militaire dienst, zonder te weten dat zij op dat moment aan het onderzoek meedoen. In praktijk levert dit problemen op. Een eenvoudiger en goedkoper alternatief is het beoordelen van schriftelijke dossiers. Bij deze werkwijze zijn de artsen op de hoogte van de toetsing. Hoewel de keuringssituatie alleen wordt nagebootst, wordt deze methode regelmatig gebruikt om de overeenstemming tussen beoordelaars na te gaan.

Bij het bepalen hoe valide een keuring is, is het ontbreken van gegevens over de afgekeurden een groot probleem. Bij militaire keuringen verdwijnen de afgekeurden namelijk uit het keuringscircuit. Er zijn daarom geen gegevens bekend of de afgekeurden daadwerkelijk niet in staat zouden zijn geweest om de dienstplicht te vervullen. Dit maakt het moeilijk de validiteit van de keuring na te gaan. Zowel de sensitiviteit, de specificiteit als de positieve voorspellende waarde kumnen hierdoor niet worden berekend.

De negatieve predictieve waarde kan wel worden bepaald met de aanwezige gegevens.

Nagegaan kan worden welk deel van de geschikt verklaarde dienstplichtigen uiteindelijk in dienst niet blijkt te functioneren. In Nederland is het disfunctioneren om andere dan medische redenen rects bij diets stplichtigen onderzocht $"$. Dat geldt niet voor het disfunctioneren on molische rodenen. Mot behulp van aanwezige gegevens kan worden acherhaald in welke matc dienstplichtigen in dienst alsnog uitvallen om medische redonen. Daarmast kunnen de redenen hiervoor worden nas'saan. Ook kan men onderzoken welke dicnstplichtigen een rohoogd risico hebben om te disfunctioneren. Aan de hand van do re risicolactoren zou men kunnen nagaan wat de consequenties zijn als men dienstplichtigen met een verhoogd risico niet in dienst laat komen.

Bij het kritisch beschouwen van de kwaliteit van de dienstplichtkeuring, valt meteen op dat enorm veel gegevens over de gezondheidstoestand van personen worden verzameld. Het medische databestand beschikt over gegevens van 4 miljoen personen. De vraag rijst of deze gegevens niet gebruikt kunnen worden voor andere doeleinden dan het bepalen van de geschiktheid als militair, zoals bijvoorbeeld voor onderzoek op het gebied van de gezondheidstoestand van de Nederlandse bevolking. 


\subsection{Vraagstellingen}

Uit het voorafgaande blijkt dat de mogelijkheden om de kwaliteit van de dienstplichtkeuring te meten beperkt zijn. Hierdoor kan men geen totaal beeld van de keuringskwaliteit verwerven. De reproduceerbaarheid kan worden vastgesteld aan de hand van onderzoek naar de overeenstemming tussen de artsen. Door het ontbreken van gegevens kan alleen aan de hand van de negatieve voorspellende waarde worden vastgesteld hoe valide een keuring is. Via een onderzoek naar de fout-negatieven, dat wil zeggen dienstplichtigen die in dienst om medische redenen disfunctioneren, kan inzicht worden verkregen in deze negatieve voorspellende waarde. Aangezien de Directie Dienstplichtzaken de hoogste prioriteit heeft gelegd bij het vroegtijdig onderkennen van medische disfunctioneerders is gekozen de voorspellende waarde als cerste te onderzoeken.

De onderzoeksvragen zijn:

- In hoeverre is het mogelijk het medisch disfunctioneren in militaire dienst te voorspellen?

- In welke mate zijn militaire keuringen reproduceerbaar? 


\subsection{De structuur van het proefschrift}

In hoofdstuk 2 wordt ingegaan op de voorspellende waarde van de keuringen. Allereerst wordt in paragraaf 2.1 het keuringstraject van de dienstplicht beschreven. Een groep dienstplichtigen wordt van begin tot einde gevolgd. Hierdoor kan worden bepald in welke mate geschikt verklaarde dienstplichtigen, niet blijken te functioneren tijdens het vervullen van de militaire dienst. Op deze wijze wordt inzicht verkregen in de mate van het medisch disfunctioneren in dienst oftewel in de voorspellende waarde van de nnedische keuring. In paragraaf 2.2 worden, met behulp van een cohortstudie, de mogelijkheden nagegaan om het medisch disfunctioneren vooraf te voorspellen aan de hand van prognostische factoren. Tevens wordt berekend wat de consequenties zijn als personen die voldoen aan de prognostische factoren niet in dicust komen.

Het kwaliteitsaspect reproduceerbaarheid wordt in hoofdstuk 3 behandeld. Eerst wordt in paragraaf 3.1 een inschatting gemaakı van de variatie van de keuringsuitslagen aan de hand van gegevens van de dienstplichtkeuringen van 1993. Om te beoordelen of de variatie veroorzakt wordt door waarnemingstouten van de heurend artsen, is een experiment uitgevoerd onder artscn die dienstplichtkcuringen verrichten. Zij beoordelen aan de hand van speciaal geselecteerde 'moeilijk beoordeclbare' casussen de geschiktheid van dienstplichtigen. De resultaten van dit onderzoek worden gepresenteerd in paragraaf 3.2. Tevens is bij artsen die periodiek geneeskundig onderzoek uitvoeren bij beroepspersoneel van de KL een soortgelijk onderzoek verricht (paragraaf 3.3). Bij dit onderzoek zijn de casussen aselect gekozen. De overeenstemming tussen de artsen wordt nagegaan.

Hoofdstuk 4 biedt een beschouwing van de resultaten. De belangrijkste bevindingen worden op een rij gezet en worden vervolgens kritisch beschouwd. Daarbij zal dieper worden ingegaan op de consequenties van selecteren. Tevens zal worden bezien of de enorme hoeveclheid data van het medische registratiesysteen te gebruiken is voor andere doeleinden dan warvoor zij primair zijn bedoeld: als basis voor onderzoeken met betrekking tot de gezondheidstoestand. Daarna worden aanbevelingen gedaan voor de verbetering van de kwaliteit van de medische militaire keuring in de huidige tijd en voor verder onderzoek. Aangegeven wordt in hoeverre de uitkomsten van dit onderzoek van belang kunnen zijn voor de discussie over medische keuringen. 


\section{Literatuur}

I Jansen J, Lourijsen ECMP, e.a. Een verkenning van voorspellend onderzoek in keuringssituaties. Bilthoven: RIVM, 1993.

2 Swaan A de. De mens is de mens een zorg. Amsterdam: Meulenhoff, 1982.

3 Commissie Hessel. Een sollicitant is ook een mens. Den Haag: Ministerie van Sociale Zaken, 1977.

4 Interdepartementale Werkgroep Aanstellingskeuringen. Goed gekeurd? Den Haag: Ministerie van Sociale Zaken en Werkgelegenheid, 1989.

5 Voorstel van wet van het lid Kohnstamm (en later Van Boxtel) houdende regels tot versterking van de rechtspositie van hen die een medische keuringen ondergaan (Wet op de medische keuringen). Tweede kamer vergaderjaar 1993-1994, 1994-1995 en 1995-1996, 23 259, nr 1-25.

6 Koninklijke Nederlandse Maatschappij tot bevordering der Geneeskunst. Protocol Aanstellingskeuringen: een protocol ten behoeve van werkgevers en artsen betrokken bij aanstellingskeuringen. Utrecht, 1995.

7 Koninklijke Nederlandse Maatschappij tot bevordering der Geneeskunst. Discussienota keuringen. Utrech, 1989.

8 Koninklijke Nederlandse Maatschappij tot bevordering der Geneeskunst. Risicokeuringen in medisch perspectief. Utrecht, 1991.

9 Commissie Medische Keuringen. Keuren en voorspellen. Den Haag: Gezondheidsraad, 1993.

10 Lourijsen ECMP, Heuvel SG van den, e.a. De prakiijk van de medische aanstellingskeuring in 1988 en 1992. Den Haag: Ministerie van Sociale Zaken en Werkgelegenheid, 1993.

I Ministerie van Sociale Zaken en Werkgelegenheid. De praktijk van medische aanstellingskeuringen 1993. Den Haag, 1994.

12 Kort WLAM de. Personnel selection through pre-employment medicals [proefschrift]. Universiteit van Amsterdam, 1993.

13 Leenen HJJ. Medische keuringen: van protocol naar wetgeving? Medisch contact 1996; 51:519-20.

14 College van Toezich Sociale Verzekeringen. Risicoselectie op de Nederlandse arbeidsmarki: selectieve aanstelling en afvloeing van personeel op grond van (vermeende) risico's binnen de Ziektewet en WAO. Zoetermeer. 1995

Militair Ketringsteglement. Staatsblad 1949, J. 404: Staatsblad 1960. 370: Staatsblad 1968, 455, en laatst hersien t.a.v. de bijlage in Staatsblad 1986, 335.

16 Leeflang $\mathrm{H}$. Eisen die de militaire personeclsdienst stelt met betrekking tot keuringen. Nederl Milit Geneesk T 1984;37:145-8.

17 Ministerie van Detensie. Prioriteitennota. Den Haăg, 1993.

18 Belloni R. De bepaling van de dienstgeschiktheid: een studie naar de bepaling vañ de dienstgeschiktheid bij de Koninklijke Landmacht, in het bijzonder van de beroepsmilitair met een verbintenis voox onbepaalde tijd. Scriptie in het kader van de opleiding verzekeringsgeneeskunde, Utrecht: Stichting voor Sociale Gezondheidszorg, 1983.

19 Berghaage EPH van den. CARA en de Koninklijke Marine, Deskundigenforum, Airways 1988: 7:40.

20 Amersfoort $\mathrm{H}$, Hoffenaar J. Nederland en de dienstplicht: een historisch overzicht. In: Commissie Meijer. Naar een dienstplicht nieuwe stijl. Den Haag: Ministerie van Defensie, 1992.

21 Romeyn D. Onze militair-geneeskundige dienst voor honderd jaren en daaromirent. Haarlem: De erven F. Bohn, 1913.

22 Ministerie van Defensie. Rapport van de projectgroep afstemming medische functie-eisen versus belastbaarheid. Den Haag, 1984. (Bijlage behorende bij PG/84-054-27) 

1965; sept:899-916.

24 Nobbe J. Dienstplichtkeuring: kritische beschouwing over de dienstplichtkeuring. Scriptie in het kader van de cursus verzekeringsgeneeskunde, Utrecht, 1979.

Ministerie van Defensie. Aanwijzingen voor artsen belast met militaire keuringen. Inclusief: Militair Keuringsreglement 1986 met bijlage. Herziene uitgave MP 35-401. Den Haag, 1987.

26 World Health Organisation. Manual of the Intermational statistical classification of diseases, injuries and causes of death: based on the recommendations of the Ninth revision conference, 1975, and adapted by the twenty-ninth World health assembly.- Geneva, 1997-2vols.

27 Lagendijk JM. De keuring voor de dienstplicht, C. Leger, aug 1966:2-3.

28 Directie Dienstplichtzaken. Jaaroverzicht dienstplichtgegevens 1993. Kerkrade: Ministerie van Defenșie, 1994.

29 Doel $M$ van den. De dienstplicht in internationaal perspectief. In: Commissie Meijer. Naar een dienstplicht nieuwe stijl. Den Haag: Ministerie van Defensie, 1992.

30 Stadt ZS. Kantekeningen bij een rapport over de maatschappelijke aspecten van aanstellingskeuringen. Nederl Milit Geneesk T 1972;25:291-306.

31 Gelooven RMW van. Dienstplichtigen over dienstplicht: verslag van een drietal onderzoeken: meningen van (ex-)dienstplichtigen, toetsing van de hypothesen Siccacama en maatschappelijk voor- of nadeel. In: Commissie Meijer. Naar een dienstplicht nieuwe stijl. Den Haag: Ministerie van Defensie, 1992.

32. Kentin FR. Roest in het uurwerk: de maatschappelijke gevolgen van de dienstplichtvervulling. Nijmegen: Katholieke Universiteit Nijmegen, Vakgroep Bestuurs- en organisatiewetenschap, 1992. Giel R. De verzekeringsgeneeskundige en de ziekenrol respectievelijk het ziekte-gedrag van de verzekerde. Arts en Sociale Verzekering 1977; 15:40-5.

34 Voùte PA. e.a. Keuringen. Leiden: Stafleu's wetenschappelijke uitgeversmaatschappij NV, 1969.

35 Bertina FM. Fitheid van KL-militairen, een continue zorg. Maandblad van het Commando Opleidingen Koninklijke Landmacht, juni 1995:1-6.

World Health Organisation. International Classification of Impairment. Disability and Handicaps: Manual of classification relating to the consequences of diseases. Geneva, 1980.

Werkgroep indelingseisen KL (WIKL), Tussenrapportage (Ta). Amersfoor: Minisierie van Defensie. 1995.

38 Siumans F. Epidemiologie: theorie, methoden en toepassing. Nijmegen: Dekker $\&$ van de Vegt, 1986.

39 Bouter LM, Dongen MCJM van. Epidemiologisch onderzoek: opzet en interpretatic. Houten/ Antwerpen: Bohn Stafleu Van Loghum, 1991.

40) Schouten HJA. Nominal Scale Agreement among Observers, Psychometrika 1986;51:453-66.

41 Feinstein AR. Clinical Epidemiology; the Architecture of Clinical Research. Philadelphia: Saunders, 1985.

42 Eck JCM van. Biografische, temperaments-en persoonlijkheidskenmerken. Een onderzock naar verschillen tussen functionerende en disfunctionerende dienstplichtig militairen bij de Koninklijke Landmacht. Den Haag: Ministerie van Defensie, 1992. 


\title{
2 MEDISCH DISFUNCTIONEREN
}

\subsection{Het keuringstraject voor dienstplichtigen van de Koninklijke Landmacht}

\author{
Gepubliceerd als: Reulings PGJ, Horst F van der, Crebolder HFJM, Sturmans F, Hofhuis PJEM, Smink \\ HAJ. Het keuringstraject voor dienstplichtigen van de Koninklijke Landmacht. Ned Milt Geneesk \\ T 1994:47:201-4
}

\section{Inleiding}

Na de Franse Revolutie van 1789 en de omwentelingen die in de Nederlanden als gevolg daarvan plaatsvonden, is ook in ons land de militaire dienstplicht ingevoerd. Sindsdien ontstond ook de vraag naar een keuringsreglement. Elk jaar werd nagegaan aan hoeveel jonge mannen van een bepaalde leeftijd het leger behoefte had. Nadat al degenen die wegens onvoldoende lengte of lichaamsgebreken als zijnde ongeschikt voor de dienst waren uitgesloten, werd door middel van loting uitgemaakt wie zou worden ingelijid.

Uit deze procedure volgde het eerste reglement op het geneeskundig onderzoek, waarin 54 gebreken stonden vermeld die leidden tot ongeschiktheid voor de militaire dienst '. Het reglement is daarna enkele malen aangepast aan de geldende medische inzichten. Momenteel geschieden de dienstplichtkeuringen aan de hand van de bepalingen van het Militair Keuringsreglement (MKR) van 1986 en de daarop betrekking hebbende dienstaanwijzingen ${ }^{2}$. Het keuringstraject is zeer uitgebreid en biedt zowel de keurling als de krijgsmacht een grote mate van rechtszekerheid. Toch is daarvan buiten de kring van direct betrokkenen weinig bekend. Teneinde meer inzicht te verschaffen in de keuring als adequaat selectie-instrument wordt in deze bijdrage het keuringstraject beschreven, zoals dit tot op heden wordt gehanteerd voor de dienstplichtigen die bij de Koninklijke Landmacht opkomen. Het traject van de dienstplichtigen die bij de andere krijgsmachtdelen opkomen wordt niet uitgewerkt, omdat bij de Koninklijke Landmacht de meeste dienstplichtigen ( $88 \%$ ) terechtkomen.

Tevens wordt verslag gedaan van de keuring van een bepaald cohort, namelijk het lichtingsjaar 1987, waarbij een beeld wordt gegeven van het aantal personen dat om medische redenen de dienstplicht niet kon vervullen ten opzichte van anderen die het traject ook hebben doorlopen.

\section{Relevantie}

Deze bijdrage is de eerste aanzet van een onderzoek naar de kwaliteit van de dienstplichtkeuring als selectie-instrument. Inzicht wordt gegeven in de omvang van het afkeuren tijdens de vervulling van de militaire dienst, ondanks het uitgebreide medische keuringsapparaat. In een vervolgonderzoek zal worden nagegaan aan de hand van welke factoren, die vóor opkomst in werkelijke dienst bekend zijn, het afkeuren in dienst beter kan worden voorzien.

Ondanks de recente opschorting van de opkomstplicht blijven de resultaten van het gepresenteerde onderzoek relevant. Zij kunnen immers ook van belang zijn voor de keuringen van beroepsmilitairen, zoals degenen die zich aanmelden als BBT'er (Beroeps Bepaalde Tijd). 


\section{Keuring voor beroepsmilitairen}

Voor de 'aanstellingskeuringen' van aspirant-beroepsmilitairen geldt een ander traject. Een belangrijk onderscheid is dat dienstplichtigen verplicht zijn een keuring te ondergaan, terwijl de kandidaten voor een functie als beroepsmilitair zich daarvoor vrijwillig aanmelden. Een ander verschil is dat de dienstplichtkeuring gericht is op de algemene geschiktheid, terwijl de keuring voor beroepsmilitairen functiegericht is.

De basis van beide soorten keuringen is echter gelijk: beide worden uitgevoerd volgens het MKR. De eisen voor de dienstplicht vormen daarbij de ondergrens voor het functioneren van het beroepspersoneel.

\section{Dienstplichtkeuring als selectie-instrument}

Bij elke Nederlandse jongeman wordt, in zijn $18 \mathrm{e}$ levensjaar, vastgesteld of hij medisch voldoet aan de eisen die aan het vervullen van de dienstplicht worden gesteld. Een dienstplichtige wordt ongeschikt verklaard wanneer hij lijdt aan een ziekte of gebrek, welke vermeld staat in de lijst van het Militair Keuringsreglement. Degene die bij het geneeskundige onderzoek niet ongeschikt wordt bevonden, wordt geschikt geacht voor het vervullen van de dienstplicht.

De keuringsprocedure biedt de mogelijkheid om op verschillende momenten een herkeuring aan te vragen. Zo kan iedereen na de eerste dienstplichtkeuring, als in zijn gezondheidstoestand een verandering heeft plaatsgevonden, om een herkeuring verzoeken.

Ondanks deze uitgebreide selectie blijkt een aantal dienstplichtigen tijdens het vervullen van de dienstplicht om medische redenen te disfunctioneren, en worden deze bij een herkeuring alsnog voorgoed ongeschikt verklaard. Deze dienstplichtigen worden ook wel 'medische disfunctioneerders' genoemd, omdat zij via het medische kanaal de dienst vroegtijdig verlaten. De medische dienstplichtkeuring wordt gehanteerd als een selectie-instrument, dat een onderscheid moet maken tussen degenen die geschikt en degenen die ongeschikt zijn voor het vervullen van de militaire dienstplicht. Bij een perfect selectie-instrument mogen alleen medische disfunctioneerders voorkomen, die disfunctioneren als gevolg van (recent ontstane) onvoorspelbare ziekten of onvoorziene ongevallen gedurende de vervulling van de militaire dienst.

\section{De keuringsprocedure}

Bij de dienstplichtkeuring zijn de keuringsuitslag en de ABOHZIS belangrijke onderwerpen. Bij iedere dienstplichtige wordt, naast de keuringsuitslag, de gezondheidstoestand vastgelegd met behulp van de ziekte- en letselcodes, conform de negende versie van de Internationale Classiticatie van Ziekten (ICD-9).

Aan iedere geschikt verklaarde persoon wordt tevens een classificatie toegekend, die wordt gebruikt als hulpmiddel bij de functie-indeling. Deze classificatie, bekend onder de naam ABOHZIS, bestaat uit zeven onderdelen; voor elk onderdeel wordt de mate van geschiktheid aangegeven door middel van een aizonderlijk cijfer. Ten overvloede vermelden wij de onderdelen van de AROHZIS-classificatie in tabel $\mathrm{l}$. 
A Algemeen fysieke toestand

B Bovenste ledematen

O Onderste ledematen

H Horen

Z Zien

I Intelligentie

5 (Psychische) Stabiliteit lichamelijke ontwikkeling, de relatie tussen lengte en gewicht, geschiktheid tot het volgen van de militaire training vorm en functie van de bovenste extremiteiten en nek vorm en functie van de onderste extremiteiten en rug toestand en functie van gehoororgaan toestand en functie van gezichtsorgaan

\section{Mate van geschiktheid}

De mate van geschiktheid wordt voor icder onderdeel afzonderlijk vastgesteld en vastgelegd door het toekennen van het klassecijfer 1, 2 of 3. In de 'Aanwijzingen voor artsen belast met. militaire keuringen' staat voor elke ABOHZIS-onderdeel omschreven aan welke eisen de keurling bij een bepaald cijfer moet voldoen.

Indien de dienstplichtige wordt afgekeurd, wordt geen ABOHZIS-classificatie toegekend, maar wordt - naast de keuringsuitslag en de ziekte- en letselcodes - de afkeuringsreden vermeld. Deze afkeuringsredenen staan in de bijlage van het Militair Keuringsreglement als zogenaamde MKR-codes.

\section{Het keuringstraject}

In figuur l staat het keuringstraject voor dienstplichtigen van de Koninklijke Landmacht grafisch weergegeven. Het traject vóór opkomst, dat voor iedere diensiplichtige betzelfde is, valt onder de verantwoordelijkheid van de Directie Dienstplichtzaken van het Ministerie van Defensie. Na opkomst in werkelijke dienst is het krijgsmachtdeel, in ons geval de Koninklijke Landmacht, verantwoordelijk voor het verdere keuringstraject.

Op 17-jarige leeftijd worden alle Nederlandse jongemannen ingeschreven voor de militaire dienst. Daarnaast wordt een jongeman, indien hij eerst na die tijd maar voor zijn $27 \mathrm{e}$ jaar de Nederlandse nationaliteit verkrijgt, 'na-ingeschreven'. In de periode tussen de inschrijving en de eerste dienstplichtkeuring bestaat in bijzondere gevallen de mogelijkheid om de keuringsuitslag 'Voorgoed Ongeschikt op Verklaring' (VOV) te verkrijgen. Dit geldı bijvoorbeeld voor personen die verblijven in een psychiatrische inrichting, een doofstommen- of blindeninstituut, een sanatorium of een soortgelijke inrichting tot verpleging van tuberculosepatiënten.

De eerste dienstplichtkeuring (de zogenaamde '10-keuring') vindt plats in het 18 e' levensjaar. De uitslag bij deze keuring kan luiden 'geschikt', 'tijdelijk ongeschikt' (TO') of 'voorgoed ongeschikt' (VO). De uitslag TO leidt, na een tijdens de keuring vastgestelde periode, tot een herkeuring ('12-keuring'). Bij deze herkeuring wordt de tijdelijke uitslag gewijzigd in een definitieve uitslag: geschikt, dan wel voorgoed ongeschikt. Indien de keurling het niet eens is met de uitslag van de keuring, kan hij - op grond van art. Il van de Dienstplichtwel - verzoeken om een herkeuring ('13-keuring'). Dit geldt ook indien cen verandering in zijn gezondheidstoestand optreedt, conform art. 21 van het Dienstplichtbesluit '. Bij de waarschuwingsoproep 
die \pm 6 maanden voor opkomst wordt verzonden, ontvangt de dienstplichtige een anamneseformulier, waarmee hij een verandering in de gezondheidstoestand kan melden. Op grond van deze gegevens kan hij worden uitgenodigd voor een extra keuring ('19-keuring'). De keuringsuitslagen van een 13- en 19-keuring luiden: geschikt, uijdelijk ongeschikt of voorgoed ongeschikt. In het geval van een tijdelijke ongeschiktheid wordt bij een daarop volgende herkeuring ('14-keuring') de definitieve uitslag bepaald.

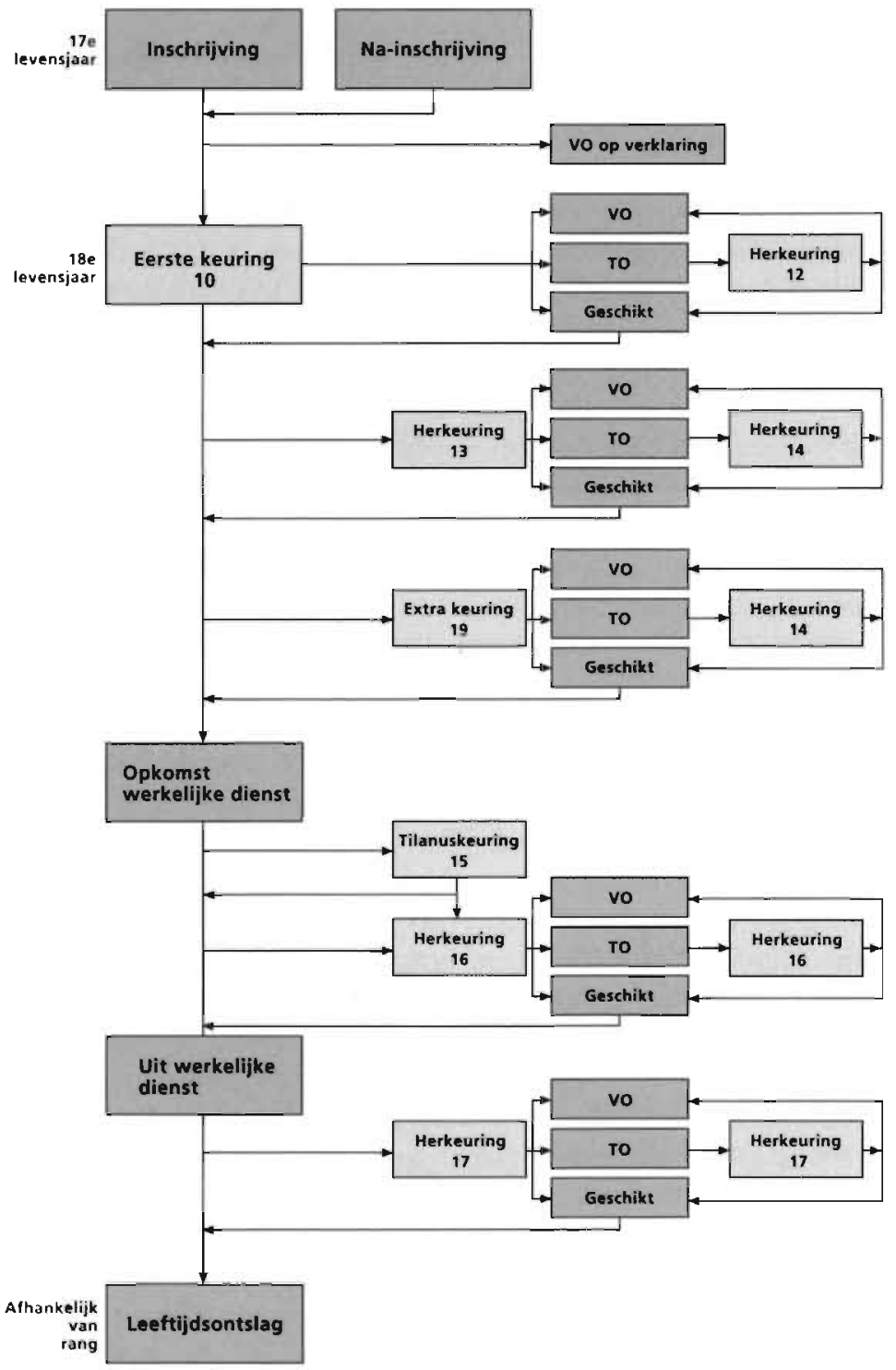




\section{Herkeuring tijdens werkelijke dienst}

Als de dienstplichtige in werkelijke dienst is, zijn er ook verschillende herkeuringsmogelijkheden. In de 6 e week na opkomst kan de Tilanuskeuring ('15-keuring') plaatsvinden; deze keuring vindt plaats wanneer de onderdeelsarts of de commandant dat nodig acht.

Indien noodzakelijk kan een gewijzigde ABOHZIS-classificatie leiden tot een functiewijziging. Als een dienstplichtige moet worden afgekeurd, wordt hij doorgestuurd voor een herkeuring in werkelijke dienst' ('16-keuring').

Bij de 16-keuring kan betrokkene geschikt, TO of VO worden verklaard. Als de dienstplichtige tijdelijk ongeschikt wordt verklaard, wordt hij na een bepaalde periode opnieuw beoordeeld, zodat een definitieve uitslag kan worden gegeven. Als de dienstplichtige geschikt is verklaard, wordt tevens vastgesteld of het gaat om een geschiktheid met of zonder beperkingen; 'geschiktheid met beperkingen' kan namelijk leiden tot een functiewijziging.

\section{Herkeuring na de eerste oefening}

Ook nadat de dicnstplichtige uit werkelijke dienst is, kan hij alsnog een herkeuring aanvragen: 'de 17-keuring'. Ook hiervan luidt de uitslag geschikt (met of zonder beperking), TO of VO; bij een TO volgt na een vastgestelde periode opnieuw een 17 -keuring om tot een definitieve uitslag te komen.

Indien naar aanleiding van een 16- of 17-keuring een dienstplichtig militair ongeschikt moet worden verklaard, dient deze ongeschiktheid en eventueel het dienstverband c.q. het verergerend dienstverband te worden vastgelegd conform het Besluit Procedure Geneeskundig Onderzoek Militairen van $1966^{\circ}$. De keuring vindt plaats door middel van een Militair Geneeskundig Onderzoek of MGO ('18-keuring').

Deze 18-keuring kan achterwege blijven in geval er geen vermoeden op dienstverband bestaat. De eerder plaatsgevonden 16- of 17-keuring kan dan worden aangemerkt als een geneeskundig onderzoek conform art. 14 van het Besluit Procedure Geneeskundig Onderzoek Militairen. Daarnaast kan de dienstplichtige zelf een 18-keuring aanvragen als hij bijvoorbeeld van mening is dat zijn klachten zijn veroorzaakt of verergerd door de dienst, of het gevolg zijn van een dienstongeval. De 18-keuring staat niet vermeld in het bij dit artikel gevoegde schema, aangezien deze keuring doorgaans plaatsvindt op een tijdstip dat de dienstplichtige reeds met zgn. groot verlof het traject heef verlaten.

\section{Cohort}

Om een indruk te given hoe het hierboven beschreven keuringstraject wordt doorlopen, werd een cohort gevolgd vanaf het moment van inschrijving. Het cohort is het lichtingsjaar 1987. dat bustaat uit jonge mannen die in 1985 het 17 e levensjaar hebben bereikt (= de ingeschrevenen), en de na-ingeschrevenen.

De resultaten van het onderzoek zijn in aantallen en percentages weergegeven in figuur 2 . waar gemakshalve naar wordt verwezen.

Naast de medische redenen, worden ook de niet-medische redenen vermeld, welke leiden tot het niet hoeven vervullen van de dienstplicht:

het krijgen van vrijstelling,

bestemd worden tot buitengewoon dienstplichtige,

\section{Keuren is Mensenwerk}




\section{- erkenning van gewetensbezwaren,}

- overige redenen: overlijden, emigratie, uitsluiting (bijwoorbeeld als gevolg van een

gevangenisstraf van minimaal 6 maanden) en zich verbinden als beroepsmilitair.

Het schema geeft duidelijk weer welke de uiteindelijke bestemming van de dienstplichtigen is. en hoe de verhouding ligt tussen medische disfunctioneerders en de overigen.

De gegevens zijn afkomstig uit het databestand 'Verdere automatisering dienstplichtzaken'. Uit figuur 2 blijkt dat voor de ingeschrevenen een uitgebreid selectie-instrument bestaat. Door deze filtering kwam van de lichting 1987 slechts $34 \%$ in dienst bij de Koninklijke Landmacht; desondanks disfunctioneerden $6 \%(\mathrm{~N}=2266)$ van deze dienstplichtigen op grond van medische redenen.

\section{Figuur 2:}

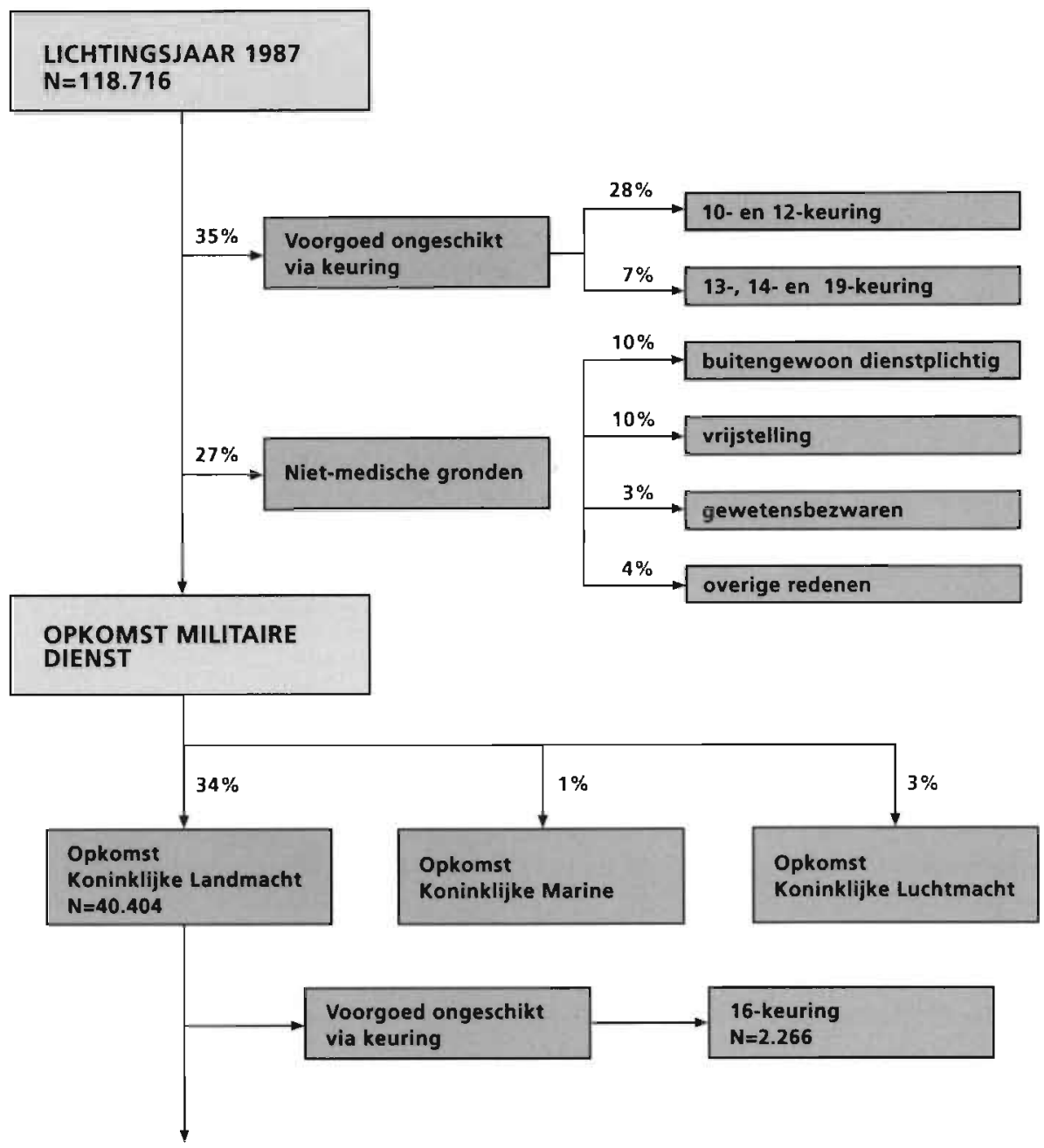




\section{Samenvatting en conclusie}

In dit artikel is het keuringstraject voor dienstplichtigen bij de Koninklijke Landmachı beschreven. Ondanks dit uitgebreide selectie-instrument blijkt van de diensıplichtigen, die bij de Koninklijke Landmacht onder de wapenen komen, zes percent om medische redenen te disfunctioneren.

Nader onderzoek zal uitwijzen of het selectie-instrument, gezien dit percentage medische disfunctioneerders, adequaat is. Immers bij een perfect selectie-instrument zouden - met uitzondering van dienstplichtigen die disfunctioneren als gevolg van onvoorziene ziekten of ongevallen - nauwelijks medische disfunctioneerders mogen voorkomen.

Dit vervolgonderzoek is juni 1992 van start gegaan bij de Afdeling Geneeskundige Aangelegenheden van de Directie Dienstplichtzaken. Prognostische factoren van het medisch disfunctioneren zullen worden geanalyseerd en uiteindelijk zullen aanbevelingen worden gedaan die kunnen leiden tot verbetering van de kwaliteit van de medische keuring. Ondanks de politieke beslissing inzake het opschorten van de opkomstplicht zijn de resultaten van het gepresenteerde onderzoek bruikbaar voor de kwaliteitsverbetering van de keuringen voor het beroepspersoneel, aangezien de geschiktheid voor de militaire dienst een minimumeis is voor de aanstelling als beroepsmilitair. Nog specifieker zou een vervolgstudie zijn die is gericht op de kwaliteit van de keuring voor de BBT'ers, waarbij de methoden van dit onderzoek als basis zouden kunnen dienen.

\section{Summary}

The medical examination of conscripts for the Royal Netherlands Army;

The various stages of the medical examination and the possibilities for re-examination of conscripts for the Royal Netherlands Army are described. Although conscription will be suspended in the near future, the data of this research are still valid for the medical examination of the future Dutch volunteer army. Despite an extensive medical selection, $6 \%$ of the conscripts who have been drafted are later discharged from the military service because of medical reasons. Further research is started to assess the selection procedures for conscripts.

\section{Literatuur}

l Romeyn D. Onze militaire diensı voor honderd jaren en daaromtrent. Haarlem: De Erven F. Bohn, 1913.

2 Ministerie vañ Defensie. Aanwijzingen voor arisen belast met militaire keuringen. Indusief: Militair Keuringsreglement 1986 met bijlage. Herziene uitgave MP 35-401. Den Haag, 1987.

3 Kiewit C.C. Dienstplichtwet: Wet van 4 febr. 1922, Stb. 43. - 9e dr. - Zwolle: Tjeenk Willink, 1990.

4 Ministerie van Defensie. Rechtspositic Militairen. Algemene maatregelen van bestuur. Besluit procedure geneeskundig onderzoek militairen (KB 31 okt 1966, Stb. 449).

Herziene uitgave MP 31-101, 1989.

\section{Keuren is Mensenwerk}




\subsection{Prognostische factoren van het medisch disfunctioneren tijdens militaire dienst bij de Koninklijke Landmacht}

Gepubliceerd als: Reulings PGJ, Sturmans F, Crebolder HFJM, Horst FG van der, Schouten HJA, Hofhuis PJEM en Smink HAJ. Prognostische factoren van het medisch disfunctioneren tijdens militaire dienst bij de Koninklijke Landmacht. Tijdschr Soc Gezondheidsz 1995;73:505-11.

\section{Inleiding}

Bij de dienstplichtkeuring wordt de geschiktheid voor het vervullen van de militaire dienst vastgesteld. Gebleken is dat $6 \%$ van de dienstplichtigen die bij de Koninklijke Landmacht (KL) in werkelijke dienst komt, tijdens het vervullen van de dienst om medische redenen gaat disfunctioneren : Dienstplichtigen die na enige tijd om medische redenen niet functioneren en in dienst worden afgekeurd, worden medische disfunctioneerders genoemd. In deze bijdrage wordt nagegaan in hoeverre het medisch disfunctioneren aan de hand van prognostische factoren beter kan worden voorspeld.

Ondanks de mogelijke afschaffing van de militaire dienstplicht is een dergelijk onderzoek relevant. De resultaten kunnen van belang zijn voor andere keuringen, zoals die voor het beroepspersoneel van de KL en de overige krijgsmachtdelen, omdat de eisen voor de dienstplicht de ondergrens voor het functioneren als beroepspersoneel vormen.

In de literatuur zijn met betrekking tot het medisch disfunctioneren van dienstplichtigen, voorzover wij konden nagaan, alleen de aantallen en redenen van afkeuring van dienstplichtigen, die bij de Koninklijke Luchtmacht zijn opgekomen, bestudeerd ?.

Het medisch disfunctioneren van beroepsmilitairen is uitgebreider onderzocht ${ }^{6.7}$. De belangrijkste redenen voor het medisch disfunctioneren van beroepsmilitairen zijn aandoeningen van de onderste ledematen en de rug. Prognostische factoren zijn nog nauwelijks bestudeerd. Een onderzoek naar de aanstellingskeuring in de burgermaatschappij wijst uit dat de mogelijkheden om de gezondheidsrisico's te reduceren door medische selectie gering is. Echter voor functies waarin gezondheids- en in het bijzonder veiligheidsrisico's groot zijn, is het nalaten van een maximale risicoreductie maatschappelijk onaanvaardbaar ". De vraag is in hoeverre dit standpunt ook geldt voor bepaalde categorieën (dienstplichtige) militairen.

\section{De medische dienstplichtkeuring}

Om prognostische factoren voor medisch disfunctioneren bij dienstplichtigen te onderzoeken is men afhankelijk van de gegevens die tijdens de dienstplichtkeuring worden verzameld. Zowel de eerste dienstplichtkeuring als de herkeuringen geschieden aan de hand van de bepalingen van het Militair Keuringsreglement (MKR) en de daarop betrekking hebbende dienstaanwijzingen ".

De keuringen zijn primair gericht op het vaststellen van de (on)geschiktheid voor de militaire dienst. Bij de geschiktverklaarden worden de geconstateerde ziekten en letsels, uitgedrukt in codes van de International Classification of Diseases (ICD-codes), vastgelegd, alsook de ABOHZIS-classificatie. Deze classificatie bestaat uit een reeks cijfers, die voor de rubrieken $A$. B, O, H, Z, I en S afzonderlijk zijn vastgesteld. De betekenis van de verschillende rubrieken is in tabel 1 weergegeven. 
Elke rubriek krijgt een klassecijfer 1, 2 of 3, waarnee géén, een lichte of een zware beperking wordt aangegeven. Tijdens de functie-indeling wordt hiermee rekening gehouden.

Tabel 1:

Betekenis van de verschillende rubrieken van de ABOHZIS-classificatie

A Algemeen fysieke toestand

B Bovenste ledematen

o Onderste ledematen

$\mathrm{H}$ Horen

Z Zien

I Intelligentie

S (Psychische) Stabiliteit lichamelijke ontwikkeling, de relatie tussen lengte en gewicht, geschiktheid tot het volgen van de militaire training vorm en functie van de bovenste extremiteiten en nek vorm en functie van de onderste extremiteiten en rug toestand en functie van gehoororgaan toestand en functie van gezichtsorgaan

De tijdelijk of voorgoed ongeschikt verklaarden krijgen geen ABOHZIS-classificatie, maar wel de ABOHZIS-rubriek waarop de afkeuringsreden betrekking heeft. Tevens wordt, naast de ICD-codes, de afkeuringsreden expliciet vermeld met behulp van een MKR-code. Deze MKRcodes staan vermeld in de bijlage van het Militair Keuringsreglement.

Indien de dienstplichtige geschikt wordt geacht voor de militaire dienst en niet om andere redenen, door bijvoorbeeld vrijstelling, het traject vroegtijdig verlaat, komt hij uiteindelijk in dienst. In werkelijke diensı bestaat de mogelijkheid om een herkeuring te krijgen. Degenen die dan worden afgekeurd zijn de zogenaamde medische disfunctioneerders.

\section{Figuur 1:}

Diterminanen van medisch disfunctioneren

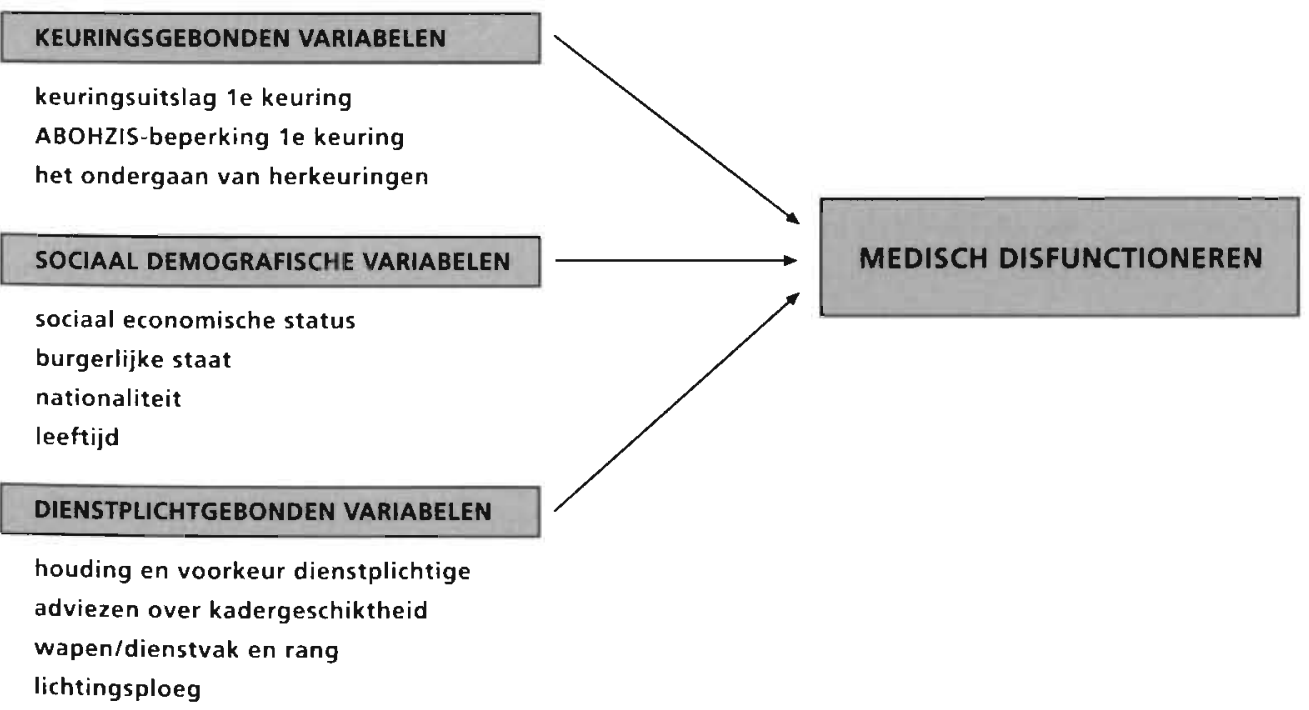




\section{Mogelijke prognostische factoren}

Het medisch disfunctioneren is afhankelijk van keuringsgebonden variabelen, maar ook is te verwachten dat sociaal demografische en dienstplichtgebonden variabelen, die betrekking kunnen hebben op de aandoeningen en het ziektegedrag van dienstplichtigen, een rol spelen. De mogelijke determinanten staan in figuur 1 weergegeven.

\section{Keuringsgebonden variabelen zijn:}

- de keuringsuitslag van de eerste keuring (geschikt, tijdelijk ongeschikt (TO) of voorgoed ongeschikt (VO));

- $\quad$ een functiebeperking uitgedrukt in de ABOHZIS-rubriek die is vastgelegd tijdens de eerste keuring: bijvoorbeeld een $\mathrm{O} 2$ of $\mathrm{O} 3$ óf een $\mathrm{S} 2$ of $\mathrm{S} 3$;

- het ondergaan van één of meer van de verschillende herkeuringen:

de herkeuring waarbij de tijdelijke ongeschiktheid, die tijdens de eerste keuring is vastgesteld, in een definitieve uitspraak moet veranderen (de zogenaamde 12 keuring), of

- de herkeuring indien de keurling het niet eens is met de uitslag van de eerste keuring of bij een verandering in de gezondheidstoestand (13-keuring), of

- de extra keuring vlak voor opkomst (19-keuring). Aanleiding daarvoor is het anamneseformulier, dat iedere dienstplichtige voor opkomst kan invullen en waaruit kan blijken dat de gezondheidstoestand dusdanig gewijzigd is ten opzichte van de vorige keuring, dat een herkeuring noodzakelijk is.

Sociaal demografische variabelen bestaan uit sociaal economische status, vastgesteld aan de hand van het opleidingsniveau; burgerlijke staat: nationaliteit en leeftijd.

Dienstplichtgebonden variabelen betreffen de houding ten opzichte van de militaire dienst, de voorkeur van de dienstplichtige voor een bepaald krijgsmachtdeel en voor bepaalde onderdelen, de bereidheid om een kaderfunctie - dat is een (onder)officiersfunctie - te vervullen en het advies over de kadergeschiktheid van de selectie-officier. Ten behoeve van de functiegegevens zijn de rang, het wapen en dienstvak tijdens de opleiding in militaire dienst vastgelegd. In 1990 zijn de dienstplichtigen om de twee maanden in een zestal groepen, de zogenaamde lichtingsploeg $1 \mathrm{l} / \mathrm{m} \mathrm{6}$, opgekomen. De samenstelling van elke lichtingsploeg kan verschillen, omdat vraag en aanbod bij elke lichtingsploeg afwijken.

De vraagstelling luidt: zijn prognostische factoren voor het medisch disfunctioneren van dienstplichtigen bij de Koninklijke Landmacht aanwijsbaar? En in hoeverre kan selectie op grond van deze prognostische factoren leiden tot een vermindering van het medisch disfunctioneren?

\section{Methoden}

\section{Onderzoeksopzet en - populatie}

Het retrospectieve cohortonderzoek is uitgevoerd bij de dienstplichtigen die bij de KL hebben gediend, omdat bij dit onderdeel van de krijgsmacht $88 \%$ van alle dienstplichtigen terecht komt. Bovendien gelden bij de overige krijgsmachtdelen andere procedures en eisen. De onderzockspopulatie bestaat uit alle dienstplichtigen die in 1989 de eerste dienstplichtkeuring hebben ondergaan en in 1990 bij de KL zijn opgekomen. $(N=8714)$ 
Uit eerdere analyses is gebleken dat van deze onderzoekspopulatie 705 militairen $(8 \%)$ medisch disfunctioneren tijdens het vervullen van de dienstplicht. De meeste medische disfunctioneerders zijn ongeschikt verklaard wegens onvoldoende psychische stabiliteit $(40 \%)$ of wegens aandoeningen aan de onderste extremiteiten en de rug $(35 \%)$. De overigen zijn afgekeurd wegens een onvoldoende algemene fysieke gezondheidstoestand (14\%), aandoeningen aan de bovenste extremiteiten (5\%), onvoldoende gezichtsvermogen $(4 \%)$, combinaties van aandoeningen van de verschillende ABOHZIS-rubrieken (1\%) of onvoldoende gehoorvermogen $(1 \%)$.

Aangezien het merendeel $(75 \%)$ disfunctioneert wegens aandoeningen, die te maken hebben met de onderste extremiteiten en de rug of gerelateerd zijn aan de psychische stabiliteit, is de rest van het onderzoek beperkt tot deze twee categorieën.

\section{Dataverzameling}

Voor de dataverzameling is gebruik gemaakt van een medisch en een niet-medisch databestand van het Ministerie van Defensie.

\section{Statistische analyse}

Via retrograde stapsgewijze logistische regressieanalyse $(a=0,05)$ wordt vastgesteld weike variabelen van figuur 1 een prognostische waarde hebben ". Met uitzondering van leeftijd en lichtingsploeg, zijn alle variabelen gedichotomiseerd. De variabele wapen en dienstvak is hier onderverdeeld naar gevechtsfuncties én ondersteunende- of verzorgende functies. Overwegend gevechtsfuncties zijn te vinden bij de Infanterie, Artillerie. Koninklijke Marechaussee, Cavalerie en Genie.

Uit de regressiecoëfficiënten (b) van het logistisch model wordt het relatieve risico met behulp van de Odds Ratio (OR) en het 95\%-betrouwbaarheidsinterval (95\% BI) berekend. Tevens wordt het logistisch model gebruikt om de kans op disfunctioneren bij keurlingen met bepaalde risicoprofielen te berekenen "

\section{Resultaten}

De frequentie van de mogelijke prognostische variabelen bij de onderzoekspopulatie wordt in tabel 2 aangegeven. 


\begin{tabular}{llll}
\hline & Totaal (\%) & O-MD*\%) & S-MD(\%) \\
Variabele & $\mathrm{N}=\mathbf{8 7 1 4}$ & $\mathrm{N}=\mathbf{2 4 3}$ & $\mathrm{N}=\mathbf{2 8 1}$
\end{tabular}

Keuringsgebonden variabelen:

Keuringsuitslag le keuring TONO

ABOHZIS-beperking 1e keuring:

Een aandoening op O-rubriek

Een aandoening op S-rubriek

O1

02

03

O-Vo (Vo op O-rubriek)

53

S-VO (VO op S-rubriek)

Het ondergaan van herkeuringen:

Herkeuring na TO 1e keuring (12-keuring)

Extra keuring n.a.v. anamneseformulier (19-keuring)

Sociaal demografische variabelen:

Lage sociaal economische status

$\begin{array}{rr}72 & 79 \\ 2 & 3 \\ 1 & 1 \\ 18 & 18\end{array}$

Bipatride nationaliteit

Burgelijke staat:samenwonen

Gemiddelde leeftijd (jaren)

Dienstplichtgebonden variabelen:

Geen positieve houding t.o.v. dienstplicht

Geen voorkeur korps mariniers

Geen voorkeur commando's

Geen voorkeur VN

Geen voorkeur luchtmobiele brigade

Geen voorkeur koninklijke marechaussee

Geen voorkeur Duitsland

Geen kaderbereidheid Voorkeur voor KLU of KM

Wapen/dienstvak met gevechtsfuncties 
Disfunctioneren wegens aandoeningen van de onderste extremiteiten en de rug

De redenen van afkeuring van de disfunctioneerders wegens aandoeningen van de onderste extremiteiten en de rug, uitgedrukt in MKR-code, zijn in tabel 3 weergegeven.

Tabel 3:

Redenen van het disfuntioneren wegens aandoeningen van de onderste extremiteiten en de rug (in procenten)

\section{MKR-codes}

0102 Ernstige aangeboren afwijkingen

0302 Goedaardige nieuwvormingen van blijvende aard, die qua localisatie leiden

tot ernstige stoornissen

0401 Chronische aandoeningen van de huid, al dan niet van infectieuze aard

0403 Chronische spieraandoeningen

0404 Ernstige chronische aandoeningen van pezen, peesscheden, peesvliezen, peesbladen of banden

0406 Scheuring, verslapping, verplaatsing of aangeboren geheel of gedeeltelijk gemis van spieren, pezen of banden

0407 Slecht genezen botbreuken

0408 Ernstige, chronische aandoeningen van beenvlies, bot, beenmerg of kraakbeen

0409 Ernstige, recidiverende ontwrichtingen

0411 Ernstige, chronische aandoeningen van de gewrichten

0501 Ernstige aandoeningen van de bloedvaten, die leiden tot verwijding, vernauwing of verstopping

0602 Chronische en/of recidiverende aandoeningen van het perifere zenuwstelsel $\mathrm{Na}$ ziekte of letsel van het zenuwstelsel overgebleven of te verwachten restverschijnselen Chronische ontstekingen, vergroeiingen, verplaatsingen of degeneratieve aandoeningen van hals-, borst, en/of lendewervels, hun tussenwervelschijven of hun gewrichten

1102 Ernstige standafwijkingen van de wervelkolom

1104 Abnormale stand en/of misvorming van het heupgewricht en/of het schouderblad

Ernstige verkorting, verkromming of misvorming van een of beide armen of benen

1111 Abnormale stand of misvorming van een voet

1112 Geheel of gedeeltelijk gemis, verstijving of abnormale stand van een of meer tenen

1115 Ernstige misvorming en/of chronische aandoeningen van éen of meer nagels

In eerste instantie is een logistische regressieanalyse uitgevoerd waarbij de variabelen 'voorkeuren voor bepaalde onderdelen' zijn betrokken. Echter de resultaten zijn tegenstrijdig en maar nauwelijks significant. Daarom zijn deze variabelen niet meer in de analyse betrokken. In het uitgebreide model van tabel 4 wordt vermeld welke prognostische factoren naar voren zijn gekomen. 


\begin{tabular}{|c|c|c|c|c|c|}
\hline \multirow[b]{2}{*}{ Factor } & \multirow[b]{2}{*}{ Waarde } & \multicolumn{2}{|c|}{ Uitgebreid model } & \multicolumn{2}{|c|}{ Eenvoudig model } \\
\hline & & b & OR (95\% BI) & $b$ & OR (95\% BI) \\
\hline \multirow[t]{2}{*}{$\mathrm{O} 2$ in $\mathrm{ABOHZIS}$} & $0=$ nee & 0,64 & $1,91(1,40-2,61)$ & & \\
\hline & $1=j a$ & & & & \\
\hline \multirow[t]{2}{*}{$\mathrm{O} 3$ in $\mathrm{ABOHZIS}$} & $0=$ nee & 1,58 & $4,88(3,22-7,39)$ & 1,37 & $3,92(2,64-5,87)$ \\
\hline & $1=j a$ & & & & \\
\hline \multirow{5}{*}{$\begin{array}{l}\text { Sociaal economische } \\
\text { status } \\
\text { Wapen en dienstvak }\end{array}$} & $\mathrm{O}=$ midden $/$ hoog & 0,34 & $1,40(1,02-1,92)$ & & \\
\hline & $1=$ laag & & & & \\
\hline & $0=$ ondersteunende $\&$ & & & & \\
\hline & verzorgende functies & 0,27 & $1,31(1,01-1,72)$ & & \\
\hline & $1=$ gevechtsfuncties & & & & \\
\hline \multirow[t]{2}{*}{ Lichtingsploeg } & $0=$ ploeg $1,2,4,5,6$ & 0,41 & $1,51(1,05-2,16)$ & & \\
\hline & $1=$ ploeg 3 & & & & \\
\hline Herkeuring na TO & $0=$ nee & 1,48 & $4,38(2,08-9,21)$ & 1,26 & $3,54(1,707,39)$ \\
\hline 1e keuring (12-keuring) & $1=j a$ & & & & \\
\hline Extra keuring n.a.v. & $0=$ nee & 1,64 & $5,15(1,54-17,29)$ & 1,61 & $4,98(1,49-16,61)$ \\
\hline anamneseformulier & $1=\mathbf{j a}$ & & & & \\
\hline \multicolumn{6}{|l|}{ (19-keuring) } \\
\hline Constante & & $-4,31$ & & $-3,69$ & \\
\hline
\end{tabular}

b: regressie-coëfficiënt; OR: Odds Ratio; 95\% Bl: $95 \%$ betrouwbaarheidsinterval

Ter vereenvoudiging van het logistisch model is een regressieanalyse uitgevoerd met factoren die een Odds Ratio groter dan 2 hebben. In tabel 4 zijn de resultaten van deze analyse in het vereenvoudigde model weergegeven. Hieruit blijkt dat een ABOHZIS-classificatie met een O3 of een herkeuring na TO-verklaring bij de eerste keuring (12-keuring) en/of een extra keuring naar aanleiding van de gegevens van het vlak vóór opkomst ingevulde anamneseformulier (19-keuring) betekenisvolle prognostische factoren zijn.

Aan de hand van het regressiemodel kan een prognostische score worden berekend en daaruit de geschatte kans om te disfunctioneren:

$\mathrm{p}=1 /(\exp (-\mathrm{score})+1)$

score $=-3.69$ (constante) +1.37 (indien O3 in de ABOHZIS van de le keuring) +1.26 (indien 12-keuring ondergaan) $+1,61$ (indien 19-keuring ondergaan)

In label 5 is de kans om te disfunctioneren voor elk mogelijk risicoprofiel volgens het eenvoudige model weergegeven. 


\begin{tabular}{lrrr}
\hline Risicoprofiel & $\begin{array}{r}\text { Voldoen aan } \\
\text { risicoprofiel }\end{array}$ & $\begin{array}{r}\text { Kans om te } \\
\text { disfunctioneren } \\
\%\end{array}$ & $\begin{array}{r}\text { Verwachte } \\
\text { aantal MDers }\end{array}$ \\
\hline O3 tijdens le keuring & 335 & 9 & 30 \\
12-keuring ondergaan & 98 & 8 & 8 \\
19-keuring ondergaan & 27 & 11 & 3 \\
O3 tijdens 1e keuring en 19-keuring ondergaan & 0 & 32 & 3 \\
12-en 19-keuring ondergaan & 9 & 33 & 44 \\
Totaal & 469 & & \\
\end{tabular}

Deze tabel geeft inzicht in hoeverre het medisch disfunctioneren kan worden teruggedrongen als dienstplichtigen met bepaalde risicoprofielen niet in militaire dienst zouden zijn gekomen. Theoretisch gezien zijn er diverse opties. De meest ingrijpende is om alle 371 dienstplichtigen met een verhoogd risico (hoger dan $8 \%$ ) niet toe te laten tot de militaire dienst. Dat zou een vermindering van 36 medische disfunctioneerders betekenen. De minst ingrijpende is om de 9 dienstplichtigen met een extra hoog risico (hoger dan 30\%) uit te sluiten, waardoor 3 medische disfuncioneerders vroegtijdig zouden zijn opgespoord.

\section{Disfunctioneren wegens onvoldoende psychische stabiliteit}

De afkeuringsredenen van de 281 disfunctioneerders vanwege onvoldoende psychische stabiliteit vallen voor $4 \%$ onder psychosen (MKR-code 0608), voor $91 \%$ onder neurotische, persoonlijkheids- en gedragsstoornissen (MKR-code 0609) en voor de overige $5 \%$ onder verslaving aan psychotrope stoffen (MKR-code 0610).

Om de prognostische factoren van het medische disfunctioneren op de S-rubriek op te sporen zijn bij de logistische regressic wederom de variabelen van het onderzoeksmodel van de figuur opgenomen in de analyse. Daarbij is 'een $01,02,03$ of $\mathrm{O}$-VO' vervangen door 'een S1, S2, S3 of S-VO'. Op basis van de regressiecoëfficienten van een eerste analyse is de variabele lichtingsploeg ten behoeve van de overzichtelijkheid gehercodeerd tot een dichotome variabele, waarbij de lichtingsplotgen 1, 2, 3 en 4 en de lichtingsploegen 5 en 6 zijn samengevoegd tot twee categorieën. De indeling van de lichtingsploegen geschiedt op basis van vraag en aanbod. Bekend is dat bij lichtingsploegen 5 en 6 geen problemen zijn met hel samenstellen van ploegen, ondat in die periode het aanbod groot is door het hoog aantal afgestudeerden. Dit in tegenstelling tor de lichtingsploegen I t/m 4 en met name lichtingsploeg 3. Het aanbod bij deze lichtingsploeg is kleiner. Daardoor komt vaker een persoon die voldoet aan de minimumeisen op een bepaalde functie terecht, in plaats van de meest geschikte persoon. 
De resultaten van de logistische regressie staan in tabel 6. De prognostische factoren die in het uitgebreide model een Odds Ratio groter dan 2 hebben, vormen de basis voor het eenvoudige model, te weien: het hebben van aandoening op de S-rubriek tijdens de eerste keuring; een bipatride nationaliteit en de opkomst in lichtingsploeg 1, 2, 3 of 4 (dat wil zeggen tussen januari en juli).

\begin{tabular}{|c|c|c|c|c|c|}
\hline \multirow[b]{2}{*}{ Factor } & \multirow[b]{2}{*}{ Waarde } & \multicolumn{2}{|c|}{ Uitgebreid model } & \multicolumn{2}{|c|}{ Eenvoudig model } \\
\hline & & & OR $(95 \% \mathrm{BI})$ & & OR $(95 \% \mathrm{BI})$ \\
\hline Aandoening op S-rubriek & $\mathrm{O}=$ nee & 0,87 & $2,38(1,59-3,55)$ & 0,83 & $2,28(1,55-3,37)$ \\
\hline 1e keuring & $1=\mathrm{ja}$ & & & & \\
\hline \multirow[t]{2}{*}{ Nationaliteit } & $0=$ Nederlands & 0,84 & $2,32(1,27-4,25)$ & 0,82 & $2,27(1,24-4,15)$ \\
\hline & 1=bipatride & & & & \\
\hline \multirow[t]{3}{*}{ Wapen en dienstvak } & $0=$ ondersteunende \& & & & & \\
\hline & verzorgende functies & 0,31 & $1,36(1,06-1,75)$ & & \\
\hline & $1=$ gevechtsfuncties & & & & \\
\hline Advies omtrent & $0=$ geschikt of & & & & \\
\hline \multirow[t]{2}{*}{ kadergeschiktheid } & twijfelachtig & 0,61 & $1,84(1,14-2,95)$ & & \\
\hline & $1=$ ongeschikt & & & & \\
\hline \multirow[t]{2}{*}{ Lichtingsploeg } & $0=$ ploeg 5 of 6 & 1,14 & $3,13(2,19-4,46)$ & 1,11 & $3,03(2,15-4,28)$ \\
\hline & $1=$ ploeg $1,2,3$ of 4 & & & & \\
\hline Constante & & $-5,12$ & & $-4,35$ & \\
\hline
\end{tabular}

In tabel 7 staat - volgens het eenvoudige model-voor elk risicoprofiel aangeven hoe groot de kans is om te disfunctioneren.

Indien alleen dienstplichtigen met een verhoogd risico (hoger dan $8 \%$ ) voor de dienst zouden worden uitgesloten, dan zouden 6 personen niet in dienst komen, hetgeen slechts 1 disfunctioneerder zou uitmaken. 


\begin{tabular}{lrrr}
\hline & $\begin{array}{r}\text { Voldoen aan } \\
\text { risicoprofiel } \\
\text { Nisicoprofiel }\end{array}$ & $\begin{array}{r}\text { Kans om te } \\
\text { disfunctioneren } \\
\%\end{array}$ & $\begin{array}{r}\text { Verwachte } \\
\text { aantal MDers } \\
\text { N }\end{array}$ \\
\hline Aandoening op S-rubriek 1e keuring & 92 & 3 & 3 \\
Bipatride nationaliteit & 52 & 3 & 2 \\
Lichtingsploeg 1 t/m 4 & 5455 & 4 & 218 \\
Aandoening op S-rubriek \& & 1 & 6 & 0 \\
bipatride nationaliteit & & & 27 \\
Aandoening op S-rubriek \& & 333 & 8 & 9 \\
lichtingsploeg 1 t/m 4 & 116 & $\mathbf{8}$ & 1 \\
Bipatride nationaliteit \& lichtingsploeg & 6 & 17 & 260 \\
Aand. op S-rubriek \& bipatride nationaliteit & & & \\
\& lichtingsploeg & & & \\
Totaal & 6055 & & \\
\end{tabular}

\section{Beschouwing}

In deze studie is de dienstplichtkeuring ais selectie-instrument geanalyseerd, ondanks de beperkingen van de onderzoeksmogelijkheden. Vanwege de frequentie van voorkomen, is de analyse beperkt tot de kans op het disfunctioneren wegens aandoeningen van de ondersie extremiteiten en onvoldoende psychische stabiliteit.

Bij het voorspellen van het medisch disfunctioneren vanwege aandoeningen van de onderste extremiteiten en de rug blijkı dat de keuringsgebonden variabelen van groot belang zijn, namelijk: een $\mathrm{O} 3$ bij de $\mathrm{ABOHZIS}$-classificatie tijdens de eerste dienstplichtkeuring; een herkeuring na de uitspraak 'tijdelijk ongeschikt' bij de eerste keuring; een extra keuring naar aanleiding van het anamneseformulier voor opkomst.

Bij het disfunctioneren vanwege onvoldoende psychische stabiliteit zijn naast de keuringsgebonden variabele 'een psychische stoornis bij eerste dienstplichtkeuring' ook sociaal demogra. fische en dienstplichtgebonden variabelen van betekenis, te weten nationaliteit en lichtingsploeg.

Getracht is de consequenties aan te geven, indien men zou overwegen om dienstplichtigen die voldoen aan het door ons beschreven verhoogde risicoprofiel uit te sluiten van de militaire dienst. Deze dienstplichtigen zou men kunnen afkeuren of buitengewoon dienstplichtig kunnen verklaren.

Ter vermindering van het aantal medische disfunctioneerders door aandoeningen van de onderste extremiteiten en de rug, valt te overwegen, iedereen met een verhoogd risicoprofiel niet op te roepen voor militaire dienst.

Met betrekking tot disfunctioneerders vanwege onvoldoende psychische stabiliteit ligt de situatie analoog. Uit beleidsmatig oogpunt zou te overwegen zijn om bepaalde risicoprofielen uit te sluiten, bijvoorbeeld die risico's hoger dan het gemiddelde. Naast selectie, kan ook naar 
andere beleidsinstrumenten worden gezocht. Deze kunnen betrekking hebben op het bijstellen vañ de indelingsmethode of op het beter begeleiden van dienstplichtigen die behoren tot bepaalde risicoprofielen.

Tevens kan meer aandacht besteed worden aan het onderkennen van aandoeningen met betrekking tot de S-rubriek met name bij personen met een bipatride nationaliteit. Hiermee heeft men in 1992 een begin gemaakt door het invoeren van een speciaal allochtonenbeleid. Bij de vraag naar de generaliseerbaarheid van de resultaten van dit onderzoek moet men zich ervan bewust zijn dat het een specifieke onderzoeksgroep betreft. De onderzoekspopulatie bestaat uit dienstplichtigen die een militaire plicht hebben, relatief kort opkomen en een keuring ondergaan die gericht is op de 'algemene inzetbaarheid'.

De onderzoekspopulatie is qua leeftijd en opleidingsniveau vergelijkbaar met de aankomende Beroeps Bepaalde Tijd (BBT'ers). De keuringen bij de beroepsmilitairen zijn gericht op de algemene inzetbaarheid én de functiegeschiktheid. Door de vrijwillige basis is sprake van zelfselectie. Bovendien worden ook andere dan medische selectiecriteria gehanteerd. De aanstellingskeuringen in de burgermaatschappij zijn alleen maar functiegericht, waarbij ook zelfselectie plaatsvindt.

De afkeuringspercentages bij dienstplichtkeuringen zijn hoog in vergelijking met de aanstellingskeuringen in de burgermaatschappij ${ }^{8}$. Dit komt enerzijds door de hoge eis van algemene inzetbaarheid en anderzijds omdat door de wettelijke verplichting van de dienstplichtkeuring geen zelfselectie kan optreden.

Gezien de huidige ontwikkelingen bij Defensie is het aan te bevelen om een specifiek onderzoek te doen naar de risicoprofielen voor het medisch disfunctioneren als BBT'er. Nagegaan moet worden of selectie op basis van risicoprofielen, hetgeen zal leiden tot een vermindering van het disfunctioneren, een middel is om gezondheid en veiligheid te waarborgen. Daarbij dient rekening te worden gehouden met het feit dat het ten onrechte niet geschikt verklaren niet alleen een persoonlijk nadeel voor de kandidaat kan opleveren, maar ook voor het

Ministerie van Defensie een verlies betekent van (schaarse) potentiële kandidaten. Indien dat het geval is, kan het beleid zich richten op een intensievere begeleiding van personen met een hoger dan gemiddelde risicoscore.

\section{Samenvatting}

Ondanks de uitgebreide medische selectie disfunctioneert $6 \%$ van de dienstplichtigen in diensttijd om medische redenen. Dit was aanleiding tot een retrospectief cohortonderzoek bij 8714 dienstplichtigen die in 1989 de eerste dienstplichtkeuring hebben ondergaan en in 1990 bij de Koninklijke Landmacht zijn opgekomen. De meeste disfunctioneerders zijn ongeschikt verklaard wegens aandoeningen van de onderste extremiteiten en de rug of onvoldoende psychische stabiliteit. Prognostische factoren van het disfunctioneren wegens aandoeningen van de onderste extremiteiten en de rug zijn: het constateren van een functiebeperking tijdens de eerste keuring op grond van aandoeningen van de onderste extremiteiten en de rug die in eerste instantie geen afkeuring leek te rechtvaardigen, of het ondergaan van een herkeuring omdat men bij de eerste keuring tijdelijk ongeschikt is verklaard en/of het ondergaan van een extra keuring naar aanleiding van de gegevens ingevuld op het anamneseformulier vlak vóór opkomst. Prognostische factoren van het disfunctioneren vanwege onvoldoende psychische stabiliteit zijn: het hebben van een psychische stoornis bij de eerste keuring die niet tot een 
afkeuring leek te hoeven leiden, een bipatride nationaliteit en terechtkomen in bepaalde lichtingsploegen. Aan de hand van de, op de prognostische factoren gebaseerde, risicoprofielen kan de kans om te disfunctioneren wegens aandoeningen van de onderste extremiteiten of onvoldoende psychische stabiliteit vóór opkomst worden berekend. Als bij de selectie hiermee rekening wordt gehouden, kan het percentage medische disfunctioneerders worden beperkt.

\section{Abstract \\ Medical dysfunctioning during military service in the Netherlands}

Despite the medical selection, a number of conscript personnel serving in the Royal Netherlands Army appear to dysfunction due to medical reasons. The main reasons for medical dysfunction can be found in disorders of the lower extremities and the back and insufficient mental stability. The predictors of these types of medical dysfunctioning have been investigated. The chances of dysfunctioning due to disorders of the lower extremities and back increase if, during the first medical examination, conscripts have been assigned a functional restriction with regard to jobs involving heavy use of the lower extremities; or if they are subjected to a medical re-examination, after having been found temporarily unfit during the first medical examination; and/or after having undergone an extra examination on the basis of an anamnesis form immediately prior to their actual enlistment. The chances of dysfunctioning due to a lack of mental stabilty increase if, during the first medical examination, a mental disturbance has been found, and/or if the conscript is a national of two countries, and /or if he ends up in certain drafts. If the above is taken into account during this selection process, medical dysfunctioning can be limited.

\section{Literatuur}

I Reulings PGJ, Horst F van der, Crebolder HFJM. Sturmans F, Hofhuis PJEM, Smink HAJ. Het keuringstraject voor dienstplichtigen van de Koninklijke Landmacht. Ned Milt Geneesk T 1994;47:201-4.

2 Alberısma T. Aantallen en reden van afkeuring van dienstplichtigen bij de Koninklijke Luchtmacht. Ned Milit Geneesk T 1986;39:1-48.

3 Lynch-Blosse H. A study into medical wastage of recruits. J R Army Med Corps 1987;133:43-9.

4 Hoof $R$ van. Hemptinne J de, Dubois $P$, Francois $R$. Evaluatie van de kans tot slagen in de opleiding voor paracommando. Ann Med Milit Belg 1989;3:106-10.

5 Jefferson TO. An investigation of medical discharges from the British Army, 1979-1986. J R Army Med Corps 1989:135:115-23.

6 Jefferson TO. An investigation into regular recruit wastage from the British Army, 1988. I R Army Med Corps 1990;136:1 38-45.

7 Kilboume B. Goodman J. Predictors of disability discharge disposition for Navy personnel with a mental health problem. Military Medicine 1990;155:542-5.

8 Kort WLAM de. Personnel selection through pre-employment medicals iproefschrift]. Universiteit van Amsterdam, 1993.

9 Ministerie van Defensie. Aanwijzingen voor artsen belast met militaire keuringen. Inclusief: Militair Keuringsreglement 1986 met bijlage. Herziene uitgave MP 35-401. Den Haag, 1987.

10 Norusis MI. SPSS Inc. SPSS/PC+ Advanced statistics, version 5.0. Chicago: SPSS Inc, 1992.

11 Hosmer DW, Lemeshow S. Applied logistic regression. New York: Wiley, 1989.

\section{Keuren is Mensenwerk}




\title{
3 REPRODUCEERBAARHEID
}

\subsection{Medisch keuren is mensenwerk. Variatie tussen artsen bij de beoordeling van de geschiktheid voor militaire dienst}

\begin{abstract}
Gepubliceerd als: Reulings PGI, Crebolder HFJM, Schouten HJA, Sturmans F, Horst van der FG, Smink HAJ en Rethans JJ. Medisch keuren is mensenwerk. Variatie tussen artsen bij de beoordeling van de geschiktheid voor militaire dienst. Tijdschr Soc Gezondheidsz 1996;74:213-6.
\end{abstract}

\section{Inleiding}

Om de medische geschiktheid van militair personeel vast te stellen worden door het Ministerie van Defensie keuringen verricht: keuringen voor vrijwillig dienende militairen en tot voor kort dienstplichtkeuringen.

Belangrijk voor een valide keuring is een hoge mate van reproduceerbaarheid. Daarmee wordt bedoeld een hoge mate van overeenstemming tussen de artsen omtrent de medische geschiktheid voor de militaire dienst van één persoon. Dat medische keuringen eventueel niet tot gelijkluidende resultaten leiden, kan worden veroorzaakt door de (biologische) variabiliteit van de keurling, door waarnemingsverschillen tussen de artsen of door tekortkomingen van het keuringsinstrument zelf.

Uit onderzoek naar de aanstellingskeuringen in de burgermaatschappij ${ }^{1 \cdot 2}$ is naar voren gekomen dat de uniformiteit van de aanstellingskeuring gering is. Bij deze keuringen ontbreekt het nog veelal aan objectieve keuringscriteria of richtlijnen. Bij de militaire keuringen wordt daarentegen gebruik gemaakt van het Militair Keuringsreglement '. Als gevolg hiervan zou een betere overeenstemming in de besluitvorming te verwachten zijn. Onderzoek heeft echter aangetoond dat meer gedetailleerde instructies ten aanzien van medische selectiecriteria slechts geringe invloed hebben op de mate van overeenstemming 4

Is bij de militaire keuringen sprake van variatie in beoordeling ? Deze vraag is in eerste instantic vanuit de Directie Dienstplichtzaken gesteld en zal met behulp van de gegevens over dienstplichtigen worden beantwoord. De wettelijke verplichting van de dienstplichtkeuring benadrukt het belang dat de kans om afgekeurd te worden onafhankelijk is van de keurend arts. De keuringen zoals die in het kader van de Diensiplichtwet worden verricht, vertonen een hoge mate van analogie met aannamekeuringen van vrijwillig dienende militairen. De basis van zowel de dienstplichtkeuringen als de keuringen van beroepsmilitairen is gelijk. namelijk het Militair Keuringsreglement. Door de opschorting van de opkomstplicht per 1 januari 1997 worden geen dienstplichtkeuringen meer uitgevoerd (totdat er door calamiteiten of oorlogsdreiging behoefte is aan dienstplichtigen). De resultaten zijn ook relevant voor keuringen van beroepsmilitairen: variabelen die de variatie van de keuringsuitspraak bij de dienstplichtkeuring beinvloeden, kunnen ook voor de keuringen van beroepsmilitairen gelden. In het kader van de Dienstplichtwet zijn jaarlijks \pm 90.000 eerste dienstplichtkeuringen verricht. Daarnaast hebben nog zo'n 15.000 herkeuringen plaatsgevonden. De eerste dienstplichtkeuringen zijn verricht bij zes over het land verspreide indelingsraden (IR). De keurlingen zijn op geografische basis over de indelingsraden verdeeld. Op elke indelingsraad waren een aantal artsen en een Voorzitter Keuringscommissie (VKC) werkzaam. 
De VKC functioneerde als hoofd van de geneeskundige afdeling van de indelingsraad. De indelingsraden werden centraal vanuit de Directie Dienstplichizaken gestuurd, maar in principe was elke raad zelf verantwoordelijk voor zijn verrichte keuringen.

Bij dienstplichtkeuringen kan de variatie beïnvloed worden door verschillen tussen de indelingsraden (inter-raadvariatie) en verschillen tussen artsen (inter-doktervariatie). Daarnaast kan de variatie ook worden veroorzaakı door de variatie binnen één arts (intra-doktervariatie) en door de (systematische) verschillen van de keurlingen over de verschillende regionale gebieden.

Om inzicht te krijgen in deze variatie zijn de gegevens van de eerste dienstplichtkeuring uit 1993 geanalyseerd. Aangezien de artsen niet dezelfde personen keuren, kan bij de analyse geen aandacht worden besteed aan de intra-doktervariatie, maar wel aan de inter-raadvariatie en de inter-doktervariatie. Het enige dat bekend is over de keurlingen is de leeftijd. Hiernaar worden de gegevens gestandaardiseerd. Voorts wordt aangenomen dat bij deze populatie geen belangrijke regionale gezondheidsverschillen aanwezig zijn. Aan de hand van de resultaten kan meer inzicht worden verkregen in de vraag of training van de artsen nodig is om de aanwezige variatie te verminderen.

De vraagstelling is: Hoe groot is de variatie tussen de artsen in keuringsuitslag bij dienstplichtkeuringen en spelen verschillen tussen de indelingsraden een belangrijke rol?

\section{Methode}

De gegevens van de eerste dienstplichtkeuringen van $1993(\mathrm{~N}=86.410)$ zijn afkomstig van het medische databestand van het Ministerie van Defensie. Bij de analyse zijn alleen gegevens verwerkı van artsen, die in dat jaar meer dan 800 keuringen hebben verricht. Vooris zijn de keuringen van de VKC's erbij betrokken. In totaal betreft het 81.037 keuringen. Deze keuringen zijn over 6 indelingsraden verdeeld en door 34 keurend artsen en 7 VKC's verricht. Op iedere indelingsraad is één VKC werkzaam. Een uitzondering vormt Roermond, omdat halverwege het jaar een keurend arts de taak van de gepensioneerde VKC heeft overgenomen. De in 1993 verrichte dienstplichtkeuringen zijn door de artsen bij steeds andere keurlingen verricht. Voorwaarde voor vergelijking tussen artsen is dat alle artsen een groep dienstplichtigen keuren met vergelijkbare gezondheidstoestand. Bekend is het geboortejaar van de keurlingen. De meesten zijn geboren in 1974 of 1975 . Van deze groep is $31 \%$ ongeschikt verklaard voor militaire dienst. Keurlingen met het geboortejaar 1976 hebben aangegeven vervioegd in dienst te willen. Derhalve worden zij vóór hun $18 \mathrm{e}$ levensjaar gekeurd. Zij hebben cen grotere kans om afgekeurd te worden dan zij die in 1974 of 1975 zijn geboren (Relatief Risico = 1.3). Degenen die vóór 1974. zijn geboren, hebben een nog grotere kans om afgekeurd te worden dan degenen die in 1974 of 1975 zijn geboren ( $R R=1.6)$. Zij zijn door omstandigheden niet tijdens hun 18 e levensjaar gekeurd, omdat zij bijvoorbeeld pas op latere leefrijd in Nederland zijn gaan wonen. Vanwege deze verschillen zijn de gegevens per aris gestandaardiseerd met de leeftijdsverdeling van de totale onderzoekspopulatie als standaard: geboortejaar vóór 1973 3,4\%, geboortejaar 1974-1975 92,4\% en geboortejaar 1976 of later $4,2 \%$.

De variatie wordt bepaald aan de hand van het afkeuringspercentage en wel specifiek voor de verschillende afkeuringsrubrieken. De arts moet namelijk bij elke ongeschiktverklaring aangeven op welke ABOHZIS-rubriek de afkeuring betrekking heeft. De betekenis van de verschillende rubrieken is als volgt: $\mathrm{A}=$ Algemeen fysieke toestand; $\mathrm{B}=$ Bovenste ledematen; 
$\mathrm{O}=$ Onderste ledematen en rug; $\mathrm{H}=$ Horen; $\mathrm{Z}=$ Zien; $\mathrm{I}=$ Intelligentie en $\mathrm{S}=$ (psychische) Stabiliteit.

Tijdens het lichamelijk onderzoek worden door een keurend arts de rubrieken A, B, O, I en S bepaald. Daarvoor of daarna worden het gehoorvermogen met behulp van een audiomaat en hei gezichtsvermogen door een opticien vastgesteld. Aan de hand van deze bevindingen beoordeelt de arts de H- en Z-rubriek. De volgorde van de beoordeling van de verschillende rubrieken is per indelingsraad verschillend; bij de ene raad is een systematische volgorde aanwezig, terwijl de volgorde bij een andere raad willekeurig geschiedt. Bij sommige indelingsraden geldt als procedure dat indien de keurling afgekeurd wordt op de $\mathrm{H}$ - of Z-rubriek en nog niet door een arts onderzocht is, een bepaalde persoon deze afkeuring verder afhandelt: bijvoorbeeld de VKC, zijn plaatsvervanger of een willekeurige arts. Hierdoor zijn verschillen tussen de artsen te verwachten.

\section{Resultaten}

In total is $62 \%$ van de keurlingen geschikt, $2 \%$ tijdelijk ongeschikt en $35 \%$ voorgoed ongeschikt verklaard.

In tabel $\mathrm{l}$ wordt per indelingsraad aangegeven op grond van welke rubrieken van de $\mathrm{ABOH}$ ZIS-classificatie de artsen keurlingen hebben afgekeurd. Bij elke indelingsraad wordt allereerst het gemiddelde percentage vermeld. Daaronder volgen de percentages van de VKC en vervolgens die van de overige artsen. De artsen zijn zodanig gerangschiki dai de arts met het hoogste afkeuringspercentage bovenaan staat. 


\begin{tabular}{|c|c|c|c|c|c|c|c|c|c|}
\hline \multirow[b]{2}{*}{ Indelingsraad } & \multirow[b]{2}{*}{ Arts } & \multicolumn{6}{|c|}{ Rubriek van afkeuring (\%) } & \multicolumn{2}{|c|}{ Totale afkeurings- } \\
\hline & & A & B & 0 & H & $\mathbf{Z}$ & 1 & $S$ & percentage \\
\hline Delft & & 13 & 1 & 13 & 7 & 6 & 1 & 5 & 46 \\
\hline & VKC & 41 & 2 & 7 & 9 & 16 & 13 & 8 & 96 \\
\hline & 1 & 10 & 2 & 26 & 7 & 4 & 2 & 14 & 64 \\
\hline & 2 & 14 & 2 & 15 & 8 & 4 & 1 & 4 & 49 \\
\hline & 3 & 11 & 1 & 15 & 6 & 5 & 0 & 4 & 43 \\
\hline & 4 & 13 & 1 & 14 & 2 & 5 & 0 & 3 & 38 \\
\hline & 5 & 12 & 1 & 8 & 7 & 6 & 0 & 2 & 36 \\
\hline & 6 & 9 & 1 & 4 & 7 & 6 & 1 & 4 & 31 \\
\hline Breda & & 13 & 1 & 10 & 5 & 4 & 2 & 6 & 40 \\
\hline & VKC & 23 & 1 & 11 & 6 & 4 & 6 & 6 & 57 \\
\hline & 1 & 19 & 1 & 15 & 7 & 3 & 2 & 7 & 53 \\
\hline & 2 & 14 & 0 & 12 & 5 & 3 & 1 & 6 & 41 \\
\hline & 3 & 10 & 1 & 9 & 5 & 3 & 2 & 8 & 38 \\
\hline & 4 & 12 & 1 & 6 & 2 & 6 & 1 & 6 & 34 \\
\hline & 5 & 11 & 1 & 7 & 6 & 5 & 0 & 3 & 32 \\
\hline & 6 & 10 & 1 & 9 & 4 & 3 & 0 & 3 & 31 \\
\hline Amsterdam & & 11 & 1 & 11 & 5 & 3 & 2 & 4 & 38 \\
\hline & VKC & 19 & 0 & 4 & 34 & 24 & 7 & 5 & 93 \\
\hline & 1 & 14 & 1 & 12 & 17 & 10 & 3 & 3 & 60 \\
\hline & 2 & 11 & 1 & 13 & 2 & 0 & 1 & 7 & 35 \\
\hline & 3 & 10 & 1 & 13 & 1 & 0 & 1 & 4 & 31 \\
\hline & 4 & 8 & 1 & 14 & 2 & 0 & 2 & 4 & 31 \\
\hline & 5 & 8 & 1 & 10 & 1 & 0 & 0 & 3 & 23 \\
\hline & 6 & 7 & 0 & 7 & 2 & 1 & 2 & 2 & 20 \\
\hline Groningen & & 12 & 2 & 7 & 7 & 3 & 2 & 3 & 36 \\
\hline & VKC & 18 & 2 & 6 & 6 & 26 & 9 & 6 & 73 \\
\hline & 1 & 15 & 2 & 11 & 12 & 4 & 2 & 11 & 56 \\
\hline & 2 & 15 & 3 & 10 & 10 & 2 & 1 & 1 & 42 \\
\hline & 3 & 11 & 1 & 8 & 8 & 4 & 2 & 2 & 38 \\
\hline & 4 & 11 & 3 & 7 & 7 & 0 & 0 & 1 & 30 \\
\hline & 5 & 10 & 1 & 6 & 5 & 0 & 1 & 2 & 26 \\
\hline & 6 & 9 & 1 & 3 & 6 & 0 & 2 & 2 & 23 \\
\hline Deventer & & 12 & 1 & 6 & 9 & 4 & 2 & 1 & 35 \\
\hline & VKC & 15 & 0 & 5 & 18 & 13 & 6 & 2 & 59 \\
\hline & 1 & 15 & 1 & 10 & 8 & 3 & 3 & 1 & 41 \\
\hline & 2 & 13 & 1 & 4 & 11 & 3 & 1 & 1 & 34 \\
\hline & 3 & 11 & 1 & 4 & 8 & 2 & 2 & 1 & 29 \\
\hline & 4 & 10 & 1 & 6 & 7 & 2 & 1 & 1 & 28 \\
\hline & 5 & 8 & 1 & 7 & 7 & 1 & 1 & 2 & 26 \\
\hline Roermond & & 9 & 1 & 6 & 6 & 5 & 1 & 2 & 31 \\
\hline & VKC1 & 24 & 2 & 7 & 4 & 8 & 11 & 6 & 62 \\
\hline & VKC2 & 11 & 2 & 8 & 8 & 6 & 4 & 4 & 43 \\
\hline & 1 & 9 & 1 & 7 & 6 & 5 & 1 & 2 & 31 \\
\hline & 2 & 9 & 2 & 7 & 5 & 5 & 0 & 2 & 30 \\
\hline & 3 & 7 & 1 & 5 & 7 & 6 & 0 & 1 & 27 \\
\hline & 4 & 6 & 1 & 5 & 7 & 5 & 1 & 2 & 26 \\
\hline & 5 & 8 & 1 & 2 & 4 & 5 & 1 & 2 & 24 \\
\hline Totaal & & 12 & 1 & 9 & 7 & 4 & 2 & 3 & 38 \\
\hline
\end{tabular}


Aangezien het mogelijk is dat een arts een keurling op meer dan één ABOHZIS-rubriek afkeurt, ligt het afkeuringspercentage berekend aan de hand van deze rubrieken hoger dan het totale afkeuringspercentage van $35 \%$, namelijk $38 \%$.

Tussen de indelingsraden verschilt het totale afkeuringspercentage: Delft heeft het hoogste afkeuringspercentage $(46 \%)$ en Roermond het laagste $(31 \%)$.

Tussen de artsen verschilt het afkeuringspercentage ook. De VKC's keuren, in vergelijking met de overige artsen, altijd een hoog percentage af. In Delft keurt de VKC zelfs $96 \%$ af. Als hoofd krijgt de VKC te maken met twijfelgevallen, waarbij een keuze tussen een tijdelijke-ongeschiktverklaring en een voorgoed-ongeschiktverklaring moet worden gemaakt. Daarnaast houdt de VKC zich bezig met afkeuringen, die op basis van een verklaring van een huisarts of specialist kunnen worden afgehandeld (zoals bij personen met het syndroom van Down). Over het algemeen keuren VKC's sporadisch met de keurend artsen mee. De variatie tussen de overige artsen is groot. Dit geldt voor de artsen binnen een indelingsraad, maar vooral als de artsen onderling worden vergeleken zonder rekening te houden met de indelingsraad waarbij ze werken. De artsen die het meest van elkaar verschillen zijn arts 6 uit Amsterdam met een afkeuringspercentage van $20 \%$ en arts 1 uit Delft die $64 \%$ afkeurt.

Specifiek kijkend naar de ABOHZIS-rubrieken, blijkt dat iets meer dan de helft van de afkeuringen geschiedt op grond van aandoeningen die onder de A- of O-rubriek vallen. De variatie tussen de keurend artsen is bij de O-rubriek het grootst: het afkeuringspercentage ligt tussen de $2 \%$ en de $26 \%$. De artsen keuren dus vooral met betrekking tot de aandoeningen van de onderste extremiteiten en de rug een verschillend percentage dienstplichtigen af. Op de $\mathrm{B}$ - en I- rubrick wordt het minst afgekeurd, de variatie is niet groot. Bij de A-, O-, H-, Z-, en Srubriek is inter-raadvariatie en inter-doktervariatie waarneembaar. Ook als de VKC's buiten beschouwing worden gelaten, keuren bepaalde artsen veel vaker af op deze rubrieken dan andere artsen: arts 1 uit Delft keurt namelijk veelvuldig af op grond van de $O$ - en S-rubriek, arts 1 uit Breda op de A- en O-rubriek en arts 1 uit Amsterdam op de H- en Z-rubriek. De variatie bij de $\mathrm{H}$ - en $\mathrm{Z}$-rubriek is, vanwege de beschikbare objectieve meetmethoden en duidelijk omschreven richtlijnen, in eerste instantie onverwacht. De variatie is echter verklarbaar door onderscheid in procedures ten aanzien van de $\mathrm{H}$ - en Z-rubriek. De procedureverschillen hebben een danig effect dat de afkeuringspercentages tussen de indelingsraden verschillen: bij de indelingsraad van Deventer wordt vaker afgekeurd op de H-rubriek (9\%) dan bij de andere indelingsraden. Uit tabel 1 is verder at te leiden dat bij sommige indelingsraden de afkeuringen op de $\mathrm{H}$ - en Z-rubriek altijd door bepaalde artsen worden behandeld. Zo worden bij indelingsraad Amsterdam de afkeuringen op grond van de $\mathrm{H}$ - en Z-rubriek overwegend afgewerkı door de VKC of zijn plaatsvervanger. Een soortgelijke regeling geldt ten aanzien van de Z-rubriek voor indelingsraad Groningen. Deze procedures hebben tot gevolg dat het totale afkeuringspercentage van de artsen, die de $\mathrm{H}$ - en Z-rubriek in die indelingsraden vaak afhandelen (zoals de artsen met nummer 1 uit Amsterdam en uit Groningen), hoger is dan het gemiddelde afkeuringspercentage. Het blijkt niet altijd zo te zijn dat deze artsen, door een verschil in volgorde van afkeuren, minder vaak afkeuren op grond van de overige $\mathrm{ABOHZIS}$-rubrieken. Bij de A-, $\mathrm{O}$ - en $\mathrm{S}$-rubriek is de variatie niet toe te schrijven aan procedureverschillen, mar aan verschillen tussen de artsen onderling. 


\section{Beschouwing}

Uit de analyse van de gegevens van de dienstplichtkeuringen van 1993 blijkt dat met betrekking tot de besluitvorming omtrent de geschiktheid voor militaire dienst aanzienlijke variatie aanwezig is. De meeste afkeuringen hebben betrekking op aandoeningen die vallen onder de A- of de O-rubriek van de ABOHZIS-classificatie, waarbij de grootste variatie bij afkeuringen van de O-rubrick aanwezig is.

\section{Wat zijn mogelijke verklaringen voor de aanwezige variatie?}

Het grootste gedeelte van de variatie is toe te schrijven aan de inter-doktervariatie. Dit wordt ook weerspiegeld in de inter-raadvariatie. Procedureverschillen veroorzaken deze variatie voor een deel: zowel door verschillen in volgorde van afkeuren als het onderscheid in afspraken over welke arts de afkeuringen op grond van de $\mathrm{H}$ - en Z-rubrick athandelt. De hoge mate van variatie bij de A-, O- en S-rubriek is niet verklaarbaar door procedureverschillen. Bij deze rubrieken is de variatie het gevolg van verschillen tussen de individuele artsen.

Het gegeven dat de variatie tussen de indelingsraden voor een groot deel te verklaren is door de verschillen tussen de artsen onderling, ondersteunt de vooronderstelling dat de regionale verschillen beperkt zijn.

Een vervolgonderzoek zal worden uitgevoerd, warbij een aantal casussen worden voorgelegd aan artsen die dienstplichtkeuringen uitvoeren. De casussen hebben betrekking op aandoeningen van de onderste extremiteiten en de rug. omdat is gebleken dat veel variatie bij de afkeuringen op de O-rubriek aanwezig is. Daarnaast blijken dienstplichtigen in dienst voor een groot deel te disfunctioneren vanwege aandoeningen van de onderste extremiteiten en de rug '. Het grote voordeel van dit type onderzoek is dat wordt voorkomen dat de variabiliteit van de keurling het design verstoort, omdat de artsen dezelfde personen 'keuren'. Met dit vervolgonderzoek hopen we meer inzicht te verkrijgen in de mate van overeenstemming tussen de artsen. Daarbij verwachten we een bevestiging te vinden dat artsen onderling verschillen en sturing vanuit de indelingsraad minimaal is. Er zal dieper worden ingegaan op de interdoktervariatie, door te onderzoeken in hoeverre contexiuele informatie invloed heeft op de besluitvorming van de arts.

\section{Samenvatting}

Bij de indelingsraden van het Ministerie van Defensie zijn jaarlijks meer dan 100.000 keuringen verricht om de geschiktheid voor de militaire dienst bij Nederlandse mannen vast te stellen. Essenticel daarbij is dat de kans om afgekeurd te worden niet afhangt van de keurend arts. Aan de hand van empirische gegevens van de dienstplichtkeuringen uit 1993 is onderzocht of variatie aanwezig is bij de beoordeling van het al dan niet geschikt zijn voor militaire dienst. lets meer dan de helft van de afkeuringen blijkt betrekking te hebben op aandoeningen die vallen onder de algemene fysieke toestand of aandoeningen van de onderste extremiteiten inclusief de rug. Zowel tussen de indelingsraden als tussen de artsen is variatie waarneembaar. De grootste variatie is aanwezig bij de afkeuringen op grond van aandoeningen van de onderste extremiteiten en de rug. De variatie is ten dele te verklaren door procedureverschillen tussen de indelingsraden met betrekking tot het afkeuren op grond van het gehoor- en gezichtsvermogen. De overige variatie tussen de indelingsraden is het gevolg van verschillen tussen de individuele artsen. 


\section{Abstract \\ Medical examinations are subject to human influences: variation in determining fitness for military service in the Netherlands}

Each year the conscription boards of the Ministry of Defence in the Netherlands carried out more than 100,000 medical examinations in order to ascertain the fitness of Dutch men for military service. An important assumption in this respect is that the likelihood of failing the examination depends on the fimess of the conscript and not on the medical examiner. On the basis of empirical data derived from concripts' medical examinations in 1993, a better understanding has been gained of the variations in determining whether a candidate is suitable for military service. About half of the conscripts who fail the medical examination do so because of ailments that fall under the categories of general physical condition or complaints that affect the lower extremities including the back. Variation is observed between the different examination boards as well as between the doctors who conduct these examinations. This variation is reflected most clearly in those conscripts rejected due to ailments of the lower extremities and back. The variation can be partly explained as a result of procedural differences between examination boards with regard to the varying visual and aural abilities. The remaining variation between the different boards is due to the differences between individual medical examiners.

\section{Literatuur}

1 Blesgraaf $\mathrm{E}$, Groenendijk $M$. Lange $\mathrm{H}$ de, Moelands $\mathrm{C}$. Uniformiteit bij aanstellingskeuringen. Tijdschr Soc Gezondheidsz 1986;64:139-43. Wely PA van. De procedure bij het keuren van sollicitanten [proefschrift]. Universiteit van Amsterdam, 1972.

3 Ministerie van Defensie. Aanwijzingen voor antsen belast met militaire keuringen. Inclusief: Militain Keuringsreglement 1986 met bijlage. Herziene uitgave MP 35-401. Den Haag. 1987. Kort WLAM de. Personnel selection through pre-employment medicals [proefschrift]. Universiteit van Amsterdam, 1993.

5 Reulings PGJ, Sturmans F, Crebolder HFJM, Horst FG van der; Schouten HJA. Hofhuis PJEM, Smink HAJ. Prognostische factoren van het medisch disfunctioneren tijdens militaire dienst bij de Koninklijke Landmacht. Tijdschr Soc Gezondheidsz 1995;73:505-11. 


\subsection{Reproduceerbaarheid van de beoordeling bij dienstplichtkeuringen}

Gepubliceerd als: Reulings PGJ, Schouten H, Rethans JJ, Crebolder HFJM, Sturmans F, Horst van der FG, Smink HAJ. Reproduceerbaarheid van de beoordeling bij dienstplichikeuringen. Tijdschr Soc Gezondheidsz 1996;74:267-71.

\section{Inleiding}

Ter beoordeling van de medische geschiktheid voor de militaire dienst worden binnen het Ministerie van Defensie dienstplichtkeuringen uitgevoerd. Onderzoeksgegevens laten een aanzienlijke variatie in deze beoordeling zien '. Variatie is niet alleen aanwezig tussen de instellingen waar de keuringen verricht worden, de zogenoemde indelingsraden, maar ook tussen de keurend artsen binnen één indelingsraad. De grootste variatie treedt op tussen de artsen onderling, welke werkzaam zijn op één van de raden (Relatief Risico=3). De oorzaken van de variatie kunnen velerlei zijn. Mogelijk spelen naast keurling- en aandoeningsgebonden variabelen ook arts- en organisatiegebonden variabelen een rol.

Onderzoek bij aanstellingskeuringen in de burgermaatschappij heeft aangetoond dat de reproduceerbaarheid niet hoog is ${ }^{24}$. Onduidelijk hierbij is welke factoren een rol spelen bij de besluitvorming.

Om meer inzicht te krijgen in de variatie bij de dienstplichtkeuringen, is dieper ingegaan op de reproduceerbaarheid van de beoordeling van de keuringsgegevens. Derhalve is een experiment uitgevoerd waarin aan keurend artsen een aantal casussen wordt voorgelegd. Getracht is de mate van overeenstemming tussen de artsen omtrent de medische geschiktheid voor de militaire dienst te bepalen. De te keuren personen, de zogenoemde keurlingen, zijn daarbij gestandaardiseerd. Daarnaast is ook onderzocht of sturing vanuit de indelingsraden invloed heeft op de mate van overeenstemming. Immers, de cultuur van een indelingsraad of de sturing door het hoofd van de artsen - de Voorzitter Keuringscommissie (VKC) - van een indelingsraad kan van invloed zijn op de besluitvorming. De bijdrage van contextuele informatie op de overeenstemming is ook nagegaan. Uit eerder onderzoek in de curatieve sector is gebleken dat ervaren (huis)artsen betere diagnostische prestaties leveren dan artsen met minder ervaring, omdat zij meer en intensiever gebruik maken van contextuele informatic over patiënten'. Daarbij gaat het om informatie die een arts over zijn patiënten heeft, zoals de medische voorkennis, risicogedrag, beroep, familiair voorkomende aandoeningen, psychosociale achtergrond en medicijngebruik. Hierbij speelt de context van de klacht een rol bij de verdere interpretatie van de klacht. Bij dienstplichtkeuringen is ook sprake van contextuele informatie. Deze informatie kan betrekking hebben op bijvoorbeeld de motivatie voor militaire dienst. De vraag is of contextuele informatie ook bij keurend artsen een rol speelt. De vraagstelling luidt derhalve: in welke mate is de beoordeling omirent de medische geschiktheid voor militaire dienst reproduceerbaar? Voorts wordt onderzocht in hoeverre sturing vanuit de indelingsraad en contextuele informatie hierbij een rol spelen.

\section{Methode}

De methode is de volgende: elk keurend arts krijgt veertien schriftelijke casussen voorgelegd en wordt gevraagd daarover een keuringsoordeel te geven.

\section{Keuren is Mensenwerk}




\section{Casuistiek}

De casussen zijn gebaseerd op bestaande dossiers, waarbij de beoordeling ten aanzien van de onderste extremiteiten en de rug moeilijk is. Er is gekozen voor aandoeningen van de onderste extremiteiten en de rug, omdat één van de belangrijkste redenen voor medisch disfunctioneren in dienst terug te voeren is naar deze categorie ${ }^{\circ}$. Bij de keuze van de casussen is getracht met zeven situaties de problematiek van de onderste extremiteiten en de rug in beeld te brengen. Aan elke casus is een casus gekoppeld die op medisch niveau vergelijkbaar is, maar war tevens contextuele informatie aan toegevoegd is. Een uitzondering hierop vormen twee casussen met multiple aandoeningen van de onderste extremiteiten. De contextuele informatie betreft de volgende aspecten; de houding van de keurling ten opzichte van de dienstplicht, de wens om beroepsmilitair of beroepsvoetballer te worden, de familie-omstandigheden, RIAGG behandeling, spijbelen, crimineel gedrag, homofiele neigingen en heimwee.

Voordat met het experiment werd begonnen is een pilot-study uitgevoerd bij artsen die als keurend arts werkzaam zijn geweest. Dit heeft ertoe geleid dat de willekeurige volgorde van de casussen is veranderd.

\section{Onderzoekspopulatie}

De onderzoekspopulatie bestaat uit de keurend artsen die dienstplichtkeuringen verrichten. De keuringen worden uitgevoerd op vijf indelingsraden en de centrale herkeuringsraad (CHR) van het Ministerie van Defensie. Op elke raad werken tussen de vier tot tien artsen en een VKC. De artsen van de indelingsraden verrichten grotendeels 'eет̈ье' dienstplichtkeuringen en enkele herkeuringen, de artsen van de CHR verrichten herkeuringen. Alle artsen dienen vast te stellen of voldaan wordt aan de eisen voor de algemene geschiktheid voor de militaire dienst, hetgeen betekent dat niet specifiek voor functies wordt gekeurd. Aan het onderzoek hebben zesendertig artsen deelgenomen. De gemiddelde werkervaring is 7 jaar (met een minimum van 4 maanden en een maximum van 18 jaar).

\section{Procedure}

Het experiment is tijdens twee groepsbijeenkomsten op de raden uitgevoerd. Gevaagd werd per casus te beoordelen: de geschiktheid voor militaire dienst, de ABOHZIS-classificatie, de aanwezige ziekten en eventueel de reden van afkeuring. Voor de bepaling van de geschiktheid voor militaire dienst kan men kiezen uit drie mogelijkheden: geschikt, tijdelijk ongeschikt (TO) of voorgoed ongeschikt (VO). De ABOHZIS-classificatie bestaat uit een reeks cijfers, die voor de rubrieken A, B, O, H, Z, I en S afzonderlijk zijn vastgesteld.

De betekenis van de verschillende rubrieken is als volgt: $\mathrm{A}=$ Algemeen fysicke toestand; $\mathrm{B}=$ Bovenste ledematen; $\mathrm{O}=$ Onderste ledematen en rug; $\mathrm{H}=$ Horen; $\mathrm{Z}=$ Zien; $\mathrm{I}=$ Intelligentie en $\mathrm{S}=$ (Psychische) Stabiliteit.

Wanneer de dienstplichtige geschikt is, krijgt (bijna) elke rubriek een klassecijfer 1, 2 of 3. Daarmee word geen, een lichte of respectievelijk een zware beperking aangegeven. Tijdens de functie-indeling wordt hiermee rekening gehouden. Bij een tijdelijk- of voorgoed-ongeschiktsverklaring moet de ABOHZIS-rubriek waarop de reden van afkeuring betrekking heeft. worden aangegeven. 
De afhankelijke variabele wordt op twee niveaus beschreven: de keuringsuitslag als zodanig én op gedetailleerder niveau de beoordeling van aandoeningen van de onderste extremiteiten en de rug, met andere woorden de O-rubriek van de ABOHZIS-classificatie. De beoordeling van de O-rubriek kan zijn:

- geschikt en ABOHZIS-classificatie OI

- geschikt en ABOHZIS-classificatie O2 (een lichte beperking)

- geschikt en ABOHZIS-classificatie O3 (een zware beperking)

- tijdelijk ongeschikt op O-rubriek

- voorgoed ongeschikt op O-rubriek

\section{Statistische methoden}

Als maat van de reproduceerbaarheid is met behulp van de groepskappa de mate van paarsgewijze overeenstemming berekend?

De groepskappa wordt als volgt berekend: Kappa $=\left(p_{0}-p_{d}\right) /\left(1-p_{0}\right)$

Hierin is $p_{0}$ respectievelijk $p_{e}$ de waargenomen (observed) respectievelijk toevallige (chance expected) overeenstemming tussen twee beoordelaars, gemiddeld over alle $36 \times 35$ tweetallen beoordelaars. In deze groepskappa wordt de gemiddelde overeenstemming gecorrigeerd voor toevallig optredende overeenstemming.

De kappa varieert tussen 0 en 1 :

$<0.40$ : geringe overeenstemming

$0.40-0.60$ : redelijke overeenstemming

$0.60-0.80:$ goede overeenstemming

$>0.80$ : voortreffelijke overeenstemming.

\section{Resultaten}

De mate van overeenstemming

Wat betreft de keuringsuitslag, staat in tabel 1 de overeenstemming tussen twee artsen, gemiddeld over alle denkbare tweetallen, in de groep van zesendertig artsen. 


\begin{tabular}{lllll}
\hline \multicolumn{2}{l}{ een andere arts } & & \\
\cline { 2 - 4 } een arts & geschikt & $\begin{array}{l}\text { tijdelijke } \\
\text { ongeschikt }\end{array}$ & $\begin{array}{l}\text { voorgoed } \\
\text { ongeschikt }\end{array}$ & totaal \\
\hline geschikt & 0,41 & 0,02 & 0,17 & 0,60 \\
tijdelijk ongeschikt & 0,02 & 0,01 & 0,01 & 0,04 \\
voorgoed ongeschikt & 0,17 & 0,01 & 0,18 & 0,36 \\
totaal & 0.60 & 0,04 & 0,36 & 1,00 \\
\hline
\end{tabular}

Uit deze tabel 1 kan worden afgeleid dat 60 procent van de gevallen geschikt wordt verklaard en dat categorie tijdelijk ongeschikt zelden is gebruikt. Tabel 2 betreft de uitslag met betrekking tot de $\mathrm{O}$-rubriek. In $(0.09+0.09=0.18) 18$ procent van de gevallen geeft de ene arts een 03, terwijl de ander een afkeuring geeft. Hieruit blijkt dat opvallend veel meningsverschillen liggen bij de keuze tussen $\mathrm{O} 3$ en VO.

Aan de hand van de, in tabel 1 en 2 weergegeven, gegevens kan de kappa voor de mate van overeenstemming ten aanzien van de keuringsuitslag als ook de beoordeling van de O-rubrieh worden berekend. Deze waarden staan in tabel 3 vermeld. Naast de kappa die de overeenstemming tussen alle artsen aangeeft, staan de kappa's vermeld in verband met de overeenkomst tussen de artsen binnen een indelingsraad en de overeenkomst tussen alle VKC's.

\section{Tabel 2:}

Dvercenstemming tusen fwee artsen geniddeld over alle $36 x 35$ artsen met betrekking tot de beoordeling van de onderste extremiteiten en de rug

\section{een andere arts}

$\begin{array}{lcccccc}\text { een arts } & 01 & 02 & 03 & \text { TO } & \text { vo } & \text { totaal } \\ \text { geschikt met O1 } & 0,07 & 0,05 & 0,02 & 0,00 & 0,01 & 0,15 \\ \text { geschikt met O2 } & 0,05 & 0,07 & 0,07 & 0,00 & 0,05 & 0,24 \\ \text { geschikt met O3 } & 0,02 & 0,07 & 0,09 & 0,01 & 0,09 & 0,27 \\ \text { tijdelijk ongeschikt (TO) } & 0,00 & 0,00 & 0,01 & 0,00 & 0,01 & 0,02 \\ \text { voorgoed ongeschikt (VO) } & 0,01 & 0,05 & 0,09 & 0,01 & 0,15 & 0,31 \\ & & & & & & \end{array}$




\begin{tabular}{|c|c|c|c|c|}
\hline \multirow[t]{2}{*}{ Populatie } & \multicolumn{2}{|c|}{ keuringsuitslag } & \multicolumn{2}{|c|}{ O-rubriek } \\
\hline & Kappa & S.E. & Kappa & S.E. \\
\hline Alle artsen & 0,20 & 0.08 & 0.17 & 0,06 \\
\hline Indelingsraad Amsterdam & 0,25 & 0,14 & 0,17 & 0,08 \\
\hline Indelingsraad Roermond & 0,19 & 0,07 & 0,17 & 0,06 \\
\hline Indelingsraad Groningen & 0,20 & 0,11 & 0,19 & 0,07 \\
\hline Indelingsraad Breda & 0,23 & 0,11 & 0,13 & 0,08 \\
\hline Indelingsraad Deventer & 0,38 & 0,17 & 0,35 & 0,13 \\
\hline Centrale herkeuringsraad (CHR) & 0,40 & 0,16 & 0,26 & 0,13 \\
\hline Alleen VKC'S & 0,20 & 0,13 & 0,19 & 0,09 \\
\hline
\end{tabular}

\section{S.E. : standaard error}

Wat betreft de keuringsuitslag geeft de kappa van 0.20 aan dat de overeenstemming tussen alle artsen gering is. De kappa is het hoogst bij indelingsraad Deventer en de CHR. Alleen bij de CHR ligt de kappa op de ondergrens van redelijke overeenstemming. Bij de VKC's onderling is de overeenstemming gering. De kappa bij de beoordeling van de O-rubriek is lager dan bij de beoordeling van de keuringsuitslag. Dit wordt mede veroorzaakt doordat in plaats van drie categorieën nu vijf́ antwoordcategoricën mogelijk. zijn. In het algemeen geldt dat de

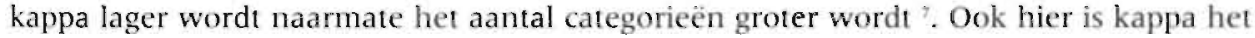
hoogst bij indelingsraad Deventer en de CHR. Deze kappa's zijn echter nog te laag om te kunnen spreken van een redelijke overeenstemming. Bij de VKC's onderling is de overeenstemming ook gering.

\section{Bijdrage van contextuele informatie}

Door de kappa van de zes casussen met contextuele informatie te vergelijken met de kappa van de zes soortgelijke casussen zonder contextuele informatie, kan de bijdrage van contextu. ele informatie aan de overeenstemming tussen alle artsen worden onderzocht (zie tabel 4). 


\begin{tabular}{|c|c|c|c|c|}
\hline & Casussen & Карра & S.E. & $\mathrm{p}$ \\
\hline \multirow[t]{2}{*}{ Keuringsuitslag } & met contextuele informatie & 0.07 & 0.05 & 0.12 \\
\hline & zonder contextuele informatie & 0.35 & 0.17 & \\
\hline \multirow[t]{2}{*}{ Beoordeling O-rubriek } & met contextuele informatie & 0.07 & 0.06 & 0.26 \\
\hline & zonder contextuele informatie & 0.21 & 0.11 & \\
\hline
\end{tabular}

Uit de vergelijking van de kappa's blijkt dat, zowel bij de keuringsuitslag als bij de beoordeling van de O-rubriek, contextuele informatie de mate van overeenstemming verlaagt, maar niet statistisch significant ?

\section{Beschouwing}

Met dit experiment is voor het eerst de mate van overeenstemming bij dienstplichtkeuringen met behulp van een gestandaardiseerde methode aangetoond. Bij moeilijk beoordeelbare casussen is de overeenkomst met betrekking tot zowel de keuringsuitslag als de beoordeling ten aanzien van aandoeningen van de onderste extremiteiten en de rug overwegend gering. Dit geldt zowel voor de overeenstemming tussen alle artsen, als tussen de artsen binnen een indelingsraad en tussen de VKC'S. Intercollegiaal overleg en de VKC hebben geen zodanig overwicht dat de arısen (van één raad) dezelfde criteria hanteren. Tevens lijkt contextuele informatie de mate van overeenstemming tussen de artsen te verlagen.

Aan de artsen zijn veertien casussen ter beoordeling voorgelegd. Dit aantal lijkt achteraf voldoende. Een sterke aanwijzing hiervoor is de lage standaard fout (S.E.) van de kappa bij de overeenstemming van alle artsen. Deze bedraagt 0.08 bij de beoordeling van de keuringsuitslag en 0.06 bij de beoordeling van de O-rubriek (zie tabel 3).

De schriftelijke casussen zijn gebaseerd op moeilijk beoordeelbare dossiers, waarbij mogelijke invloeden van niet-medische aspecten, zoals sturing door collega's binnen de indelingsraad en contextucle informatie, een grotere rol zullen spelen dan bij eenduidige casussen. Het beoordelen van schriftelijke dossiers is voor de keurend artsen een lastig karwei, omdat het geen dagelijkse bezigheid is. Een uitzondering vormen de VKC's en de artsen van de CHR.

Desondanks is de overeenstemming tussen de VKC's gering, terwijl de artsen op de CHR redelijk overeenstemmen. Een mogelijke verklaring zou kunnen zijn dat op de CHR dagelijks contact russen de artsen plaatsvindt, terwijl de VKC's sporadisch overleg hebben.

De VKC's zijn de aangewezen personen om nieuw personeel in te werken. Aangezien zij onderling niet overeenstemmen in hun beleid, is het niet verwonderlijk dat de arisen die door verschillende VKC's zijn ingewerkt, ook niet met elkaar overeenstemmen.

Bij de gepresenteerde casussen is de contextuele informatie van dien aard dat de diversiteit in beoordeling bevorderd wordt. In de huisartsenpraktijk is contextuele informatie hypothesesturend, terwijl bij de beslissing wel of niet geschikt voor militaire dienst contextuele informatie ruis met zich meebrengt. Om meer inzicht te verkrijgen is verder onderzoek nodig dat dieper ingaat op de verschillende soorten contextuele informatie. 
Welke adviezen zouden we nu op basis van deze gegevens kunnen geven om de overeenstemming te vergroten?

Een beleidsmatig advies is gericht op het aanpassen van het keuringsbeleid. Het afschaffen van de keuring is onaanvaardbaar, ondat het gaat om functies met grote gezondheids- en veiligheidsrisico's. De mogelijkheden om deze risico's in het werk te beïnvloeden zijn gering *. Een betere oplossing is om, zoals de overheid wenst, bij beroepen waarbij gevaar is voor de gezondheid en/of veiligheid van betrokkene of derden, functiegericht te keuren ". Het slecht reproduceerbare $A B O H Z I S$-systeem, dat dient als functie-indelingscriterium, hoeft dan niet meer te worden gehanteerd. Het systeem om in een grote groep personen in te delen gaat hiermee verloren. Indien men de ABOHZIS-classificatie niet wil afschaffen, zou men het afkappunt kunnen verleggen en alleen keurlingen die minimaal een $\mathrm{O} 2$ hebben in diensi kunnen laten komen. Gebleken is dat de keuze tussen een $\mathrm{O}_{3}$ of VO moeilijk is. Daarnaast blijken keurlingen met een $\mathrm{O} 3$ een verhoogde kans te hebben om te disfunctioneren tijdens militaire dienst ". Bij deze afweging dienen de consequenties van een strenger afkappunt, zoals een toename van het aantal onterecht afgekeurden, te worden meegenomen. Indien functiegericht keuren alleen niet voldoende is om de overeenkomst te vergroten, kan men overwegen artsen zich te laten specialiseren in het beoordelen van specifieke functies of functiegroepen die voor een deel dezelfde functie-eisen hebben. De ene arts neemt bijvoorbeeld de administratieve functies voor zijn rekening, terwijl de andere arts zich bezighoudt met de gevechtsfuncties. Tegelijkertijd is het van belang voldoende doorstroommogelijkheden binnen de specialisaties te creëren, zodat artsen zich bekwamen in een scala van functiegroepen en de daarbij behorende specifieke problematiek. Op deze wijze kan eentonigheid en onvoldoende werkmotivatie worden voorkomen. Een ander voordeel van deze doorstroommogelijkheid is dat bij ziekte of verlof de artsen vervangbaar zijn. Andere adviezen richten zich op trainingen voor artsen en met name voor instructeurs (bijvoorbeeld de VKC's), zodat laatstgenoemden in staat zijn de artsen een zo uniform mogelijk beleid aan te leren. Daarnaast zou een systematische casusbespreking en intercollegiale toetsing kunnen bijdragen tot een hogere reproduceerbaarheid. Hierbij zou, naast medische aspecten, aandacht kunnen worden besteed aan de betekenis van contextuele informatie.

Verder onderzoek zal nodig zijn om na te gaan in hoeverre de gestelde adviezen ten goede komen aan de reproduceerbaarheid.

Bij vervolgonderzoek zou, door de opschorting van de opkomstplicht, de groep beroepsmilitairen een geschikte onderzoekspopulatie zijn. De basis van de keuring is heizelfde namelijk de algemene geschiktheid. Daamaast worden speciale eisen gesteld aan functiegroepen, hoewel net - zoals in de 'burgermaatschappij' - specifieke medische functieeisen nog veelal ontbreken.

\section{Samenvatting}

Door het Ministerie van Defensie worden dienstplichtkeuringen verricht. De reproduceerbaarheid van dit keuringsproces is bepaald aan de hand van de overeenstemming tussen keuringsresultaten van de artsen. Daarvoor is een experiment uitgevoerd, waarbij een aantal geselecteerde casussen, met betrekking tot aandoeningen van de onderste extremititeiten en de rug, aan de keurend artsen zijn voorgelegd. Bij de beoordeling van de geschiktheid voor de militaire dienst blijkt de overeenstemming tussen artsen overwegend gering te zijn.

\section{Keuren is Mensenwerk}


De invloed vanuit de indelingsraad op de overeenstemming blijkt niet groot te zijn.

Intercollegiaal overleg en het hoofd van de artsen op de indelingsraad hebben niet een zodanig overwicht dat de artsen van eenzelfde raad hetzelfde beleid voeren. Tevens lijkt contextuele informatie de overeenstemming tussen artsen te verlagen. Ter verbetering van de overeenstemming zou men kunnen overwegen functiegericht te keuren. Een nadere uitwerking daarvan zou kunnen zijn dat artsen zich specialiseren in de beoordeling van specifieke functie(groepen). Daarnaast zou meer aandacht kunnen worden besteed aan intercollegiaal overleg en trainingen voor keurend artsen en vooral voor degenen die de artsen inwerken.

\section{Abstract \\ Reproducibility of the assessment in conscripts' medical examinations in the Netherlands}

The Dutch Ministry of Defence conducts medical examinations for its military conscripts. The reproducibility of this examination procedure is characterized by inter-observer variation. To examine this observation more closely an experiment was conducted in which a number of selected cases was presented to medical examiners in charge of the routine examinations of conscripts. In those cases involving assessment of disorders of the lower extremities, the interobserver agreement is low. The influence of the conscription board on inter-observer agreement appears to be small. Consultation between colleagues and steering by the head of the medical commission does not result in medical examiners of the same board consistently applying the same criteria. In addition contextual information appears to have a negative affect on inter-observer agreement. In order to improve the inter-observer agreement certain recommendations can be made, for instance by conducting examinations which focus on the assigned job description. Further the examiners themselves could specialize in the examination of candidates for specific occupational functions. Also more training could be given to medical examiners and more emphase on intercolleagueal consultation. 


\section{Literatuur}

I Reulings PG.J, Crebolder HFJM, Sturmans F, Horst FG van der, Smink HA.J, Rethans JIJ. Medisch keuren is mensenwerk: een analyse van de variatie omtrent bepaling van de geschiktheid voor militaire dienst. Tijdschr Soc Gezondheidsz. 1996;74:213-6.

2 Blesgraaf E, Groenendijk M, Lange $\mathrm{H}$ de, Moelands $\mathrm{C}$. Uniformiteit bij aanstellingskeuringen. Tijdschr Soc Gezondheidsz 1986;64:139-43.

3 De Kort WLAM, Post Uiterweer HW. Project Aanstellingskeuringen. Dossieronderzoek bij de RBB. Deel II: Panelonderzoek. Den Haag: Ministerie van Sociale Zaken en Werkgelegenheid, 1991.

4 Lourijsen ECMP, Dam J. Het keurings- en besluitvormingsproces bij aanstellingskeuringen: cen voorstudie onder tien artsen, Leiden: NIPG/TNO, 1990.

5 Hobus PPM. Expertise van huisartsen: praktijkervaring, kennis en diagnostische hypothesevorming [proefschrift]. Rijksuniversiteit Limburg, 1994.

6 Reulings PGJ, Sturmans F, Crebolder HFJM, Horst FG van der, Schouten HJA. Hofhuis PJEM, Smink HAJ. Prognostische factoren voor het medisch disfunctioneren tijdens militaire dienst bij de Koninklijke Landmacht. Tijdschr Soc Gezondheidsz. 1995;73:505-11.

7 Schouten HJA. Nominal Scale agreement among observers. Psychometrika 1986;51:453-66.

8 De Kort WLAM. Personnel selection through pre-employment medicals [proeischrift]. Universiteit van Amsterdam, 1993.

9 Koninklijke Nederlandse Maatschappij tot bevordering der Geneeskunde. Protocol Aanstellingskeuringen, Utrecht, 1995. 


\subsection{Reproduceerbaarheid van de heoordeling bij periodiek geneeskundig onder- zoek van de Koninklijke Landmacht}

Gepubliceerd als: Raad de J, Reulings PGJ, Schouten HJA. De beperkingen van medische beperkingen De reproduceerbaarheid van de beoordeling van de ABOHZIS-classificatie en de medische beperkingen bij periodiek geneeskundig onderzoek bij de Koninklijke Landmacht. Ned Milt Geneesk Tijdschrift 1996; 49:106-11.

\section{Inleiding}

\section{Aanleiding}

Sinds 1960 worden beroepsmilitairen van de Koninklijke Landmacht (KL) door middel van het periodiek geneeskundig onderzoek (PGO) om de vijf jaar gekeurd om te beoordelen of zij op medische gronden nog geschikt zijn om als militair te kunnen blijven functioneren. De militair wordt opgeroepen om te verschijnen bij één van de twee Keuringsraden, die ressorteren onder de Directie Personeel KL / Sous-Chef Geneeskundige Dienst / Geneeskundige Aangelegenheden (DPKL/SCGD/GA). De keurend arts heeft bij dit onderzoek inzage in het curatieve dossier van de keurling. Het PGO bestaat uit een gestandaardiseerde anamnese, lichamelijk onderzoek en biometrie. Bij dit laatste behoren een ecg in ruste, audiometrie, bepaling van de visus, kleuronderscheidingsonderzoek volgens Ishihara of de draadboomtest en urine-onderzoek.

$\mathrm{Na}$ afloop deelt de keurend arts de voorlopige uitslag en de voorlopige medische beperkingen aan de militair mede. Hierna wordt de uitslag met de voorzitter van de Keuringsraad besproken en wordt het keuringsformulier met de adviezen naar de DPKL/SCGD/GA gezonden. Bij de afdeling GA wordt de definitieve keuringsuitslag vastgesteld. Aansluitend worden evenutele functioneringsbeperkingen door een vertegenwoordiger van de DPKL / Sous-Chef Personeelszaken / Beheer Beroepspersoneel Onbepaalde Tijd / Bureau Normstelling en Toetsing (DPKL/SCPZ/BBOT/NET) vastgesteld.

Ten gevolge van de Defensienota (1991) en de Prioriteitennota (1993) is de taakstelling van de KL. uitgebreid. Deze veranderde taakstelling brengt een verzwaring van de belasting met zich mee. Biovendien blijkt er overtolligheid onder beroepsmilitairen van de KL te bestaan. Niet voor elke militair zal er in 1998, wanneer de gevolgen van de Prioriteitennota ten volle zijn gemplementeerd, werk zijn. De veranderde taakstelling en de dreigende overtolligheid waren de oorzaken van een verhevigde belangstelling binnen de KL. voor de actuele medische inzetbaarheid van de individuele militair.

In 1994 werd een onderzoek naar de kansen op behoud van werk voor beroepsmilitairen voor 1998, uitgevoerd (project LoopbaanPrognose). Hierbij werd als onderdeel tevens onderzocht in hoeverre de thans in werkelijke dienst zijnde beroepsmilitairen anno 1998 inzetbaar zouden zijn op basis van de medische beperkingen '. De hierbij gevolgcle procedure was dat én arts een voorselectie pleegde op basis van de keuringsgegevens. Hierna werden de vermoedelijke gevallen waarbij sprake was van verminderde inzetbaarheid en de groep waarover twijfel bestond, in een vaste commissie van drie artsen besproken. Tijdens bovengenoemd onderzoek deden zich een aantal vragen voor over de keuringsprocedure welke bij de KL wordı gevolgd. Er was nimmer onderzoek verricht naar de overeenkomst tussen de beoorde- 
lingen van de keurend artsen (inter- en intra-observers agreement), evenmin was ooit beoordeeld of het toetsingssysteem (keurend arts - voorzitter keuringsraad - arts GA) dat voor deze keuringen bij de KL wordt gehanteerd, effectief was.

In een poging om na afloop van het project op deze vragen antwoord te krijgen is een onderroek verricht naar de reproduceerbaarheid van de medische beperkingen zoals die bij het PGO van de KL worden vastgelegd.

\section{Achtergrondinformatie}

Voor medische eisen te stellen aan militairen wordt gebruik gemaakt van het Militair Keuringsreglement (MKR), tezamen met de 'lijst van ziekten en gebreken' 2. Deze 'lijst' bestaat thans uit 282 genummerde aandoeningen. Bij de beschrijving van die aandoeningen worden vaak toevoegingen als 'hardnekkig', 'belangrijk' of 'in belangrijke graad' vermeld. Lijdt een militair onverkort aan een van de in de lijst vermelde aandoeningen of gebreken, dın is hij/zij ongeschikt voor de militaire dienst. In de regel volgt ontslag, dan wel geen aanstcelling.

Daarbij wordt tevens gebruik gemaakt van het ABOHZIS-systeem. Dit systeem is in 1946 overgenomen van het Amerikaanse leger. De letters ABOHZIS staan voor Algemene fysieke tocstand, Bovenste extremiteiten, Onderste extremiteiten, Horen, Zien, Intelligentie en Stabiliteit. Door het gebruik van dit systeem worden de aandoeningen en gebreken in 7 aandachtsgebieden onderverdeeld. Hierbij werd oorspronkelijk per deelgebied een gradering van 1 tot 5 gehanteerd. Ofschoon het ABOHZIS-systeem oorspronkelijk slechts bedoeld was om de indeling van personeel na de aanstellingskeuring te vergemakkelijken, wordt het vanal 1960 ook voor de periodieke beoordeling van de diensigeschiktheid (PGO) toegepast. De alandoeningen uit de lijst van het MKR worden als het ware op deze wijze verdeeld over de diverse deelgebieden uit de ABOHZIS.

In 1967 gaf de toenmalige Inspectie Militair Geneeskundige Dienst (IMGD) de 'Aanwijzingen voor artsen belast met militaire keuringen' uit '. Hiermee wordt een koppeling gemaakt tussen vele ziektecodes uit de International Classification of Diseases (ICD-9, een internationale codering van ziekten en gebreken) en een specifieke ABOHZIS-classificatie. Daardoor werd het ABOHZIS-systeem met 282 algemeen omschreven aandoeningen en gebreken, in feite uitgcbreid tot een veelvoud aan circumscripte onderzoeksbevindingen en diagnosen. Lijdt een militair nu niet aan een aandoening of gebrek zoals in de 'lijst' vermeld, dan wordt hij/zij beschouwd als geschikt voor de militaire dienst. Indien de militair in mindere mate aan zo'n aandoening of gebrek lijdt dan wordt hij/zij niet ongeschikt verklaard, maar krijgt medische beperkingen opgelegd. De keurend arts verstrekt de ABOHZIS-classificatie die bij deze ândoening hoort en verstrekt zo nodig medische beperkingen, b.v. 'geen zware rugbelasting'. In de loop der jaren is het dienstgeschikt verklaren van militairen steeds meer beperkt. Op dit moment is de minimale ABUHZIS om bij de $\mathrm{KL}$ te worden aangenomen A2 B2 $\mathrm{O} 2 \mathrm{H} 2$ Z3 I2 SI 4 .

Ook voor het verstrekken van de medische beperkingen wordt van een standaardlijst gebruik gemaakt, ontwikkeld door de afdeling GA. Er is geen consensus over de vraag bij welke aandoening men welke medische beperkingen dient te verstrekken, maar de lijst is wel verdeeld in de rubrieken A, B,O,H,Z,I, en S. Frequent gebruikt zijn: A02 ('geen hindernisbaan'), A06 ('geen zware lichamelijke inspanning'), Olo ('geen zware rugbelasting'), O20 ('geen zware

\section{Keuren is Mensenwerk}


velddiensten'), B10 ('geen zware nekbelasting') en S07('betrokkene mag geen geestelijk stresserende werkzaamheden verrichten').

Zowel de medische als de functioneringsbeperkingen worden vervolgens naar de individuele militair, de commandant van de militair en de onderdeelsarts gezonden. Tevens wordt een copie van dit formulier ('het groentje') in het personeelsdossier opgeslagen ".

De commandant kan nu bepalen aan welke in zijn onderdeel verplichte activiteiten deze militair al dan niet kan participeren. Eventueel kan de commandant ook van oordeel zijn dat de vermelde medische en functioneringsbeperkingen tot gevolg hebben dat deze militair niet langer bij het onderdeel kan functioneren, of zelfs ongeschikt is voor de militaire dienst. Dit laatste komt zelden voor, omdat bij het vermoeden op ongeschiktheid voor de militaire dienst reeds bij de afdeling GA door de geneeskundig adviseur actie word ondernomen. Hij bespreekı deze gevallen met de vertegenwoordiger van de DPKL/SCPZ/BBOT/NET. (Het is niet onmogelijk dat de centrale rol van DPKL/SCPZ in de nabije toekomst zal worden vervangen door de commandanten van de Resultaat Verantwoordelijke Eenheden.) Indien in deze bespreking dit vermoeden wordt bevestigd ', dan wordt de betrokken militair voor een Militair Geneeskundig Onderzoek (MGO) of commissoriaal onderzoek voorgedragen ?. Bij dit commissoriaal onderzoek wordt in de eerste plaats de geschiktheid voor de militaire dienst vastgesteld. Dit is een alles-of-niets situatie; men is het wel of niet.

Daarnaast wordt beoordeeld of er sprake is van 'dienstverband'. Dit wil zeggen dat het vervullen van de taken als militair de ongeschiktheid voor de militaire dienst heeft veroorzaakt. Indien er sprake is van dienstverband wordt de mate van invaliditeit vastgesteld. Als laatste wordt de mate van arbeidsongeschiktheid geschat in het kader van de WAO.

\section{Nadelen}

Aan het boven beschreven systeem kleven een aantal nadelen. Nog afgezien van onderzoek dat de relatieve waarde van het ecg in ruste heeft aangetoond :, alsmede de vraag waarom periodiek het kleuronderscheidend vermogen telkens opnieuw dient te worden vastgesteld, is reeds vanaf 1984 bekend dat het onderzoek resulteert in een ABOHZIS-classificatie die niet functiegericht is en onvoldoende gericht is op de arbeidssituatie".

Sterker nog: wordt de ABOHZIS-classificatie nog wel na de aanstellingskeuring door personeelsfunctionarissen gebruikt ten behoeve van de indeling van nieuwe militairen, er is geen enkele instantie die gebruik maakt van de ABOHZIS-gegeveñs die uit de PGO's voortkomen. Oorspronkelijk bood de ABOHZIS-classificatie de mogelijkheid om aandoeningen in 5 graden in te delen, in de loop der jaren is dit beperkt. Thans kan nog slechts worden gekozen uit 1, 2 of ' $\mathrm{X}$ ' (met uitzondering van de Z-classificatie, waarbij wel een ' 3 ' mag worden verstrekt). Met de $X$-score wordt het vermoeden op ongeschiktheid voor de militaire dienst weergegeven. Hierdoor ontstaat een systeem waarbij de aard van de aandoening ondergeschikt wordt aan de classificatie, terwijl de mogelijkheden tot nuancering worden beperkt. En dat was de reden waarom het systeem oorspronkelijk is opgezet ${ }^{10}$.

Bovendien word bij de keuring weliswaar een beoordeling van de belasıbaarheid opgemaakt en worden er functiebeperkingen opgelegd, maar van functie-eisen is in medisch opzicht geen sprake. Ofwel: de belasting is niet bekend, de belastbaarheid kan niet zorgvuldig tegenover de belasting worden afgewogen. 
Het MKR zelf geeft ook aanleiding tot discussie. De 'lijst' dateert uit 1966 en is in 1986 op enkele details gewijzigd; sindsdien zijn de inzichten in de pathologie alsmede de therapeutische mogelijkheden veranderd, respectievelijk toegenomen. Bovendien kent het MKR hetzelfde gewicht toe aan aandoeningen of gebreken uit het verleden als aan actuele aandoeningen of gebreken. Om een concreet voorbeeld te geven: wie eenmaal aan een hnp L4-L.5 heeft geleden, hoe lang geleden ook, kan op formele gronden ongeschikt voor de militaire dienst worden verklaard. Ongeacht de status praesens.

Als laatste wordt het in Nederland op dit ogenblik voor onmogelijk gehouden om met een 5 jaarlijkse PGO aan risicowering te doen ${ }^{11.12}$.

Vele van deze nadelen kwamen voort uit het gegeven dat dit systeem voomamelijk was bedoeld om dienstplichtigen te keuren. Hierbij gold een maximale risicowering: wie ook maar iets mankeerde, kon gemakkelijk worden afgekeurd.

Dat hetzelfde systeem ook sinds 1960 voor beroepspersoneel gold werd mogelijk gemaakt doordat zowel de Minister van Defensie als de hoogste geneeskundige autoriteit bij de KL, de Inspecteur Geneeskundige Dienst KL (IGDKL), de mogelijkheid hebben om dispensatie te verlenen. Bovendien was er geen sprake van overtolligheid. In 1993 heeft de Bevelhebber der Landstrijdkrachten (BLS) evenwel aan de SCGD kenbaar gemaakt dat hij er prijs op stelt indien van dat recht tot dispensatie zo min mogelijk gebruik wordt gemaakı.

\section{Vraagstelling}

Met dit onderzoek wordt getracht meer inzicht te krijgen in de gehanteerde methoden on de medische beperkingen van de militair vast te leggen. Indien men de kwaliteit van keuringen wenst te meten zijn er drie mogelijkheden "

a men onderzoekt de validiteit (makkt de keuring een terecht onderscheid tussen geschikten en ongeschikten?)

b men doet onderzoek naar de voorspellende warde van een keuring (blijkt iemand later in de tijd daadwerkelijk geschikt, dan well ongeschikt te zijn?)

c men beoordeelt de reproduceerbaarheid (betrouwbaarheid) van keuring. Dit kan door de overeenkomst tussen artsen na te gaan.

De eerste twee mogelijkheden zijn in de praktijk zeer bewerkelijk dan wel slechts beperkt na te gaan, derhalve is ervoor gekozen om naar de reproduceerbạarheid te kijken. De vraagstelling van het onderzoek luidt dan ook als volgt:

Is de beoordeling van de ABOHZIS-classificatie en de medische beperkingen, zoals die bij het PGO van de KL worden vastgesteld, reproduceerbaar en komt de gegeven ABOHZIS-classificatie overeen met de toegekende medische beperkingen?

\section{Methoden}

Uit een bestand van circa 200 keuringsformulieren van PGO's, die in 1994 door de keurend artsen van één keuringsraad zijn verricht, doorgesproken met de voorzitter en afgehandeld door GA, zijn 24 formulieren aselect gekozen.

Hieronder bevinden zich 6 keuringsformulieren waarbij geen medische beperkingen voor wat betreft de A-, B- en O-classificatie zijn vastgesteld. De formulieren zijn geanonimiseerd en ontdaan van de vastgestelde ABOHZIS-classificatie en medische beperkingen. 
Alle informatie, inclusief eventuele brieven van klinisch specialisten, is overgenomen.

Deze 24 keuringsformulieren zijn ter beoordeling aangeboden aan twee artsen van de andere keuringsraad te Den Haag; een ervaren keurend arts en een keurend arts met een werkervaring van ongeveer 6 maanden. Aan beide keurend artsen is gevraagd zowel de ABOHZIS-classificatie als de medische beperkingen vast te stellen. De beoordeling van de oorspronkelijke arts (beoordelaar 1) wordt vervolgens vergeleken met de beoordeling van de ervaren arts (beoordelaar 2) en de minder ervaren arts (beoordelaar 3).

\section{Statistische methoden}

De mate van overeenkomst tussen de drie beoordelaars wordt aan de hand van een groepskappa aangegeven ${ }^{14}$ : dit betreft zowel de ABOHZIS-classificatie als de medische beperkingen conform de lijst van GA.

Ten aanzien van de ABOHZIS is voor de bepaling van de $\mathrm{H}$ - en Z-classificatie biometrie noodzakelijk; deze is niet altijd in het keuringsformulier opgeslagen, terwijl de uitslag op een nietgestandaardiseerde wijze wordt vermeld. Bovendien komt het uiterst zelden voor dat een militair op grond van visus of gehoor dienstongeschikt wordt verklaard. Mede omdat militairen bij een gecombineerde 12- en S2-classificatie ongeschikt worden verklaard bij de aanstellingskeuring zijn er relatief weinig militairen bij wie tijdens het PGO een afwijkende I-of Sclassificatie wordt vastgesteld.

De belangrijke parameters die bij de bepaling van de dienstongeschiktheid de grootste rol spelen zijn de A-, B-en O-classificatie. Kappa wordt derhalve uitsluitend voor deze drie classificaties berekend.

Kappa varieert tussen 0 en 1 . De indeling is als volgt:

$<0.40 \quad$ : geringe overeenstemming

0.40-0.60: redelijke overeenstemming

0.60-0.80: goede overeenstemming

$>0.80$ : voortreffelijke overeenstemming.

Om de mate van overeenstemming tussen de artsen met betrekking tot de A-, B- en O-classificatie vast te stellen, worden per rubriek twee kappawaarden berekend. De eerste kappa geeft de mate van de overeenstemming op de vier afzonderlijke scores $1,2, \mathrm{X}$ of ? weer. De tweede kappa betreft de overeenstemming op de score 1 tegenover de combinatie 2, X of ?. De scores 2. $X$ of ? worden hier als gelijkwaardig beschouwd; deze drie scores betekenen dat een aandoening of een gebrek aanwezig is.

Wat betreft de medische beperkingen wordt de overeenkomst bekeken over het wel of niet toekennen van een beperking op een bepaalde rubriek. Nagegaan wordt of de artsen meer overeenstemmen bij het toekennen van de ABOHZIS-classificatie dan bij het toekennen van een medische beperking.

De eerlijkheid gebiedt om alleen twee kappa's met elkaar te vergelijken als het in beide gevallen om een dichotomie gaat (slechts twee mogelijkheden). Teneinde twee gecorreleerde kappa's met elkaar te kunnen vergelijken is de 'jackknife techniek' gebruikt, analoog aan de gepaarde t-toets 15 .

Tenslotte zal bekeken worden of de artsen consequent omgaan met het toekennen van medische beperkingen. De overeenkomst tussen de beperkingen in termen van de A-, B- en $\mathrm{O}$ - 
classilicatic en de medische beperkingen wordt voor elke arts vastgesteld met behulp van kappa. Duarbij worden gedichotomiseerde variabelen met elkaar vergeleken. Er is overeenstemming indien een arts enerzijds een $\mathrm{Al}, \mathrm{Bl}$ of $\mathrm{Ol}$ geef terwijl hij/zij anderzijds op deze rubriek ge'n medische beperkingen aangeeft. Evenzeer dienen bij een andere A-.B- of O-classificatie juist wel medische beperkingen te zijn vermeld.

\section{Resultaten}

De $A$-, B-en O-classificatie

In tabel 1 is voor alle 24 keuringsformulieren de toegekende ABOHZIS van de drie beoordelaars weergegeven.

\section{Tabel 1:}

De door de 3 artsen bij de 24 PGO's toegekende ABOHZIS-classificaties `

beoordelaar 1

$\begin{array}{llllllll}\text { nr } & \text { A } & B & O & H & Z & \text { I } & S\end{array}$

3

4

5

6

$7 *$

\section{8}

$9 *$

10

11

12

13

14

15

16 *

17

18

19

20 *

21

22

$23 *$

24

\section{beoordelaar 2}

$\begin{array}{lllllll}A & B & O & H & Z & \text { I }\end{array}$

$\begin{array}{lllllll}1 & 1 & 1 & 2 & \times & 1 & 1\end{array}$

$\begin{array}{lllllll}X & 1 & 1 & 2 & 1 & 1 & 1\end{array}$

$\begin{array}{lllllll}2 & 1 & \times & ? & 1 & 1 & 1\end{array}$

$2119 ? 11$

$11 \times 1 ? 11$

$2111 ? 11$

$\begin{array}{lllllll}1 & 1 & \times & 1 & 2 & 1 & 1\end{array}$

$22 \times$ ? ? 12

$2 ? ?$

$1111 \times 11$

$\begin{array}{llllll}\times 12111 & 1\end{array}$

$\begin{array}{lllllll}2 & 1 & 1 & ? & ? & 1 & 1\end{array}$

? ? $\times 12$ ? ?

$\begin{array}{rlllll}\times 1111 & 111\end{array}$

$\begin{array}{llllll}\times 11 & 1 & 1 & 1\end{array}$

$\begin{array}{lllllll}2 & 1 & 1 & ? & 1 & 1 & 1\end{array}$

$\times 22 ? 211$

$11 \times 1 \times 11$

$\begin{array}{lllllll}X & 1 & 2 & 1 & 1 & 1 & 1\end{array}$

$\times 114111$

$\begin{array}{llllll}\times 111211 & 1\end{array}$

$\times 1 \times ? \times 11$

$\begin{array}{lllllll}2 & 2 & 1 & ? & 1 & 1 & 1\end{array}$

$\begin{array}{r}\times 11211 \\ \hline\end{array}$ beoordelaar 3

$\begin{array}{lllllll}A & B & O & H & Z & \text { I } & \text { S }\end{array}$

\section{": oorspronkeliik geen medische beperking}


De door de oorspronkelijke keurend arts voorgestelde ABOHZIS wordt door de afdeling GA zelf in alle gevallen gehandhaafd. Opmerkelijk genoeg is door alle drie beoordelaars toch in een aantal gevallen een X-score verstrekt. Dit zou in feite moeten leiden tot nader onderzoek naar de ongeschiktheid voor de militaire dienst. In sommige gevallen wordt als advies aan de aldeling GA over 'dispensatie' gesproken. In enige gevallen is in de vermelde afweging sprake van niet-medische overwegingen, bijvoorbeeld door de medische beperkingen aan te passen op grond van leefrijd van de gekeurde of diens uitgesproken wens om voortijdig af te willen vloeien. De beoordelaars 2 en 3, die beiden 'papieren keuringen' hebben verricht, hebben in sommige gevallen aangegeven de verstrekte informatie onvoldoende te vinden.

De oorspronkelijke beoordelaar heeft gebruik gemaakt van de mogelijkheid om een ABOHZIS 1, 2 dan X te verstrekken; beoordelaars 2 en 3 gebruikten soms ook '?' als score. In de dagelijkse prakzijk: hebben de beoordelaars 2 en 3 ook de mogelijkheid een '?' te geven en dit voor te leggen aan het hoold van de keuringsraad.

In tabel 2 zijn de kappa's voor alle drie de beoordelaars tezamen beoordeeld.

De mate van overeenkomst is per A-, B- of O-rubriek bekeken. Eerst wordt kappa vermeld voor de afzonderlijke A-, B- of $\mathrm{O}$-score zijnde 1, 2, $\mathrm{X}$ of ?. De tweede kappa betreft de overeenstemming bij het vaststellen of er géén (score 1) of wél (score $2, X$ of ?) een aandoening of beperking is, een tweedeling ofwel dichotomie.

Tabel 2:

Mate van overeenkomst tussen de beoordelaars met betrekking tot de rubrieken $A, B$ en $O$ van de ABOHZIS en de medische beperkingen, uitgedrukt in kappa

\begin{tabular}{lllll}
$\begin{array}{l}\text { ABOHZIS } \\
\text { rubriek }\end{array}$ & \multicolumn{2}{l}{$\begin{array}{l}\text { ABOHZIS-classificatie } \\
\text { dichotoom }\end{array}$} & MEDISCHE BEPERKINGEN \\
\hline A & $1,2, X$ ? & 0,32 & 0,67 & \\
B & 0,16 & 0,58 & 0,74 & $p_{2}=0,07$ \\
O & 0,52 & 0,67 & 0,65 & $p_{2}>0,10$ \\
& 0,44 & & & $p_{2}>0,10$
\end{tabular}

De eerste kappawaarde geeft aan dat de mate van overeenstemming per rubriek verschillend is. De overeenkomst tussen de artsen bij de A-rubriek is gering. Bij de B-rubriek en O-rubriek is de overeenkomst redelijk. De geringe overeenstemming bij de A-rubriek kan worden virklaard doordat de onervaren beoordelaar meestal een '?' geeft, hetgeen de oorspronkelijke beoordelaar 1 niet gebruikt als score. 
De mitische beperkingen

In tabel 3 staan de medische beperkingen weergegeven. De codes staan voor specifieke medische beperkingen, zoals onder 'Achtergrondinformatie' is vermeld.

Tabel 3: De door de 3 arisen bij de 24PGO's toegekende medische beperkingen

\begin{tabular}{|c|c|c|c|}
\hline \multicolumn{4}{|c|}{ formulier } \\
\hline nr & beoordelaar 1 & beoordelaar 2 & beoordelaar 3 \\
\hline 1 & $\mathrm{H} 04$ & $\mathrm{HO4}$ & \\
\hline 2 & A06 & $\mathrm{A} 06, \mathrm{~A} 43, \mathrm{Ax}$ & $\mathrm{A} 09, \mathrm{~A} 43$ \\
\hline 3 & $\mathrm{~A} 20,004,018,019,020$ & $A 20,004,019$ & $A 20,004$ \\
\hline 4 & $\mathrm{~A} 05++, \mathrm{A06}, \mathrm{A08}, \mathrm{Ay}$ & $\mathrm{A} 05, \mathrm{A06}, \mathrm{A} 34$ & $\mathrm{~A} 06, \mathrm{A09}, \mathrm{Ay}$ \\
\hline 5 & $007,011,018,020,027,030$ & $007,018,019,020,027,030$ & $007,018,027$ \\
\hline 6 & $\mathrm{~A} 06, \mathrm{~A} 34++$ & $\mathrm{A} 05, \mathrm{~A} 06, \mathrm{~A} 34++$ & $A 09 . A 34$ \\
\hline \multicolumn{4}{|l|}{$7^{\star}$} \\
\hline 8 & $\mathrm{~A} 20, \mathrm{~B} 12, \mathrm{~B} 21, \mathrm{OW}, \mathrm{S} 14$ & $\mathrm{~A} 20, \mathrm{~S} 14$ & \\
\hline \multicolumn{4}{|l|}{$9^{\star}$} \\
\hline 10 & A14 & & A18 \\
\hline 11 & 010.027 & 010 & \\
\hline \multicolumn{4}{|l|}{$12^{*}$} \\
\hline 13 & $007,018,020,027,028,036,0 z$ & $\mathrm{~A} 20,007,027,030$ & $007,018,027$ \\
\hline 14 & $\mathrm{~A} 06, \mathrm{Ax}$ & $\mathrm{A} 06, \mathrm{Ax}$ & \\
\hline 15 & $\mathrm{~A} 06, \mathrm{~A} 34$ & $\mathrm{AO}, \mathrm{HO} 04$ & $\mathrm{~A} 10, \mathrm{Ax}$ \\
\hline $16^{\star}$ & $\mathrm{HO4}$ & & \\
\hline \multirow[t]{2}{*}{17} & $\mathrm{~B} 04, \mathrm{~B} 10, \mathrm{~B} 17, \mathrm{~B} 21, \mathrm{O} 10,018$ & $\mathrm{~A} 06, \mathrm{~A} 09, \mathrm{~A} 20, \mathrm{~B} 04, \mathrm{~B} 07, \mathrm{~B} 10$ & $\mathrm{~A} 06, \mathrm{~B} 07, \mathrm{~B} 10$ \\
\hline & $\mathrm{O} 21, \mathrm{O} 27, \mathrm{H} 04, \mathrm{~S} 11$ & $\mathrm{~B} 14+, 817,010,018,020$ & \\
\hline 18 & $010,014+, 018,020,027,0 x$ & 010,014 & $010,018,027$ \\
\hline 19 & $\mathrm{~A} 06, \mathrm{~A} 20,011,014,018, \mathrm{O} 20+$ & $A 09, A 11, A 24$ & $A 20, A x$ \\
\hline $20 *$ & & $\mathrm{~A} 06, \mathrm{~A} 20, \mathrm{~A} 34$ & \\
\hline 21 & $\mathrm{~A} 06, \mathrm{~A} 12, \mathrm{Ax}, \mathrm{S} 07$ & $A 05, A 06, A 12, A 34$ & $\mathrm{~A} 12$ \\
\hline 22 & $009,012,014,027$ & 204,207 & \\
\hline \multicolumn{4}{|l|}{$23^{\star}$} \\
\hline 24 & $A 06, A 09, A 11, A x$ & $A 09, A 11, A 24$ & $\mathrm{~A} 06, \mathrm{~A} 11, \mathrm{Ax}$ \\
\hline
\end{tabular}

*: oorspronkelijk geen beperkingen; +/++: gemodificeerde medische beperking uit de lijst van de afdeling GA; w/X/y: niet in de lijst met voorgeschreven medische beperking voorkomende opgelegde beperkingen

De beoordeling van de medische beperkingen van de oorspronkelijke arts is grotendeels overgenomen door de afdeling GA; van 69 medische beperkingen handhaafde de afdeling GA bij het toekennen van de definiticve medische beperkingen er 62 en voegde er in totaal 1 aan toe. Het is moeilijk aan te geven of de artsen inhoudelijk overeenstemmen in de toekenning van de medische beperkingen. Inhoudelijk geven de codes van de beperkingen niet altijd een 
medische beperking aan. Daarnaast is er ook veel overlap in de lijst met medische beperkingen aanwezig; sommige beperkingen, afkomstig uit verschillende rubrieken zijn identiek.

De overeenkomst tussen de artsen met betrekking tot het wel of niet toekennen van een medische beperking op een A-, B- of $\mathrm{O}$-rubriek is met kappa vastgesteld. Uit tabel 2 blijkt dat deze overeenkomst tussen de artsen voor elke rubriek als goed kan worden beschouwd.

Bij de A-rubriek is de overeenstemming bij de medische beperkingen beduidend hoger dan de overeenstemming bij de A-rubriek van het ABOHZIS-classificatiesysteem, maar net niet significant. Bij de B-en O-rubriek is het verschil in kappawaarden bij lange na niet significant.

De overeenkomsi mssen de ABOHZIS en de medische beperkingen

In tabel 4 staat aangegeven in hoeverre de drie artsen bij de A-, B- en O-rubriek consequent omgaan met het toekennen van medische beperkingen. Bij elke arts is per rubriek de relatie tussen de gegeven A-, B- en $\mathrm{O}$-score en het wel of niet toekennen van cen medische beperking op de betreffende rubriek vastgesteld.

Tabel 4: De overeerkomst tussen de toegekende ABOHZIS en medische beperkingen bij de 3 beoordelaars

\begin{tabular}{|c|c|c|c|c|c|c|}
\hline \multirow[t]{2}{*}{ ABOHZIS } & \multicolumn{2}{|c|}{$\begin{array}{l}\text { beoordelaar } 1 \\
\text { medische beperking }\end{array}$} & \multicolumn{2}{|c|}{$\begin{array}{l}\text { beoordelaar } 2 \\
\text { medische beperking }\end{array}$} & \multicolumn{2}{|c|}{$\begin{array}{l}\text { beoordelaar } 3 \\
\text { medische beperking }\end{array}$} \\
\hline & geen & wel & geen & wel & geen & wel \\
\hline$A 1$ & 7 & 1 & 5 & 0 & 1 & 0 \\
\hline$A 2, A X, A ?$ & 5 & 11 & 6 & 13 & 13 & 10 \\
\hline kappa & \multicolumn{2}{|c|}{0,50} & \multicolumn{2}{|c|}{0,47} & \multicolumn{2}{|c|}{0,06} \\
\hline B1 & 20 & 0 & 19 & 0 & 18 & 0 \\
\hline$B 2, B X, B ?$ & 2 & 2 & 4 & 1 & 4 & 2 \\
\hline kappa & \multicolumn{2}{|c|}{0,63} & \multicolumn{2}{|c|}{0,28} & \multicolumn{2}{|c|}{0,43} \\
\hline 01 & 11 & 0 & 13 & 0 & 10 & 0 \\
\hline $02,0 \times, 0 ?$ & 4 & 9 & 5 & 6 & 10 & 4 \\
\hline kappa & \multicolumn{2}{|c|}{0,67} & \multicolumn{2}{|c|}{0,57} & \multicolumn{2}{|c|}{0,25} \\
\hline
\end{tabular}

De overeenkomst tussen de ABOHzIS en de medische beperking bij de oorspronkelijke beoordelaar is redelijk tot goed. Bij de andere twee beoordelaars is de overeenkomst geringer, namelijk slecht tor redelijk.

Alle drie artsen zijn het vrijwel met elkaar eens dat bij een Al, Bl of ol geen medische beperkingen worden toegekend. Echter, vaak komt het voor dat geen medische beperkingen worden aangegeven en toch de desbetreffende ABOHZIS-score niet 1 is, maar $2, \mathrm{X}$ of ?. 


\section{Beschouwing}

Formeel zijn keurend artsen niet gewend om een oordeel 'vanaf het papier' te geven; in de dagclijkse praktijk keuren zij fysiek. Anderzijds adviseren keurend artsen bij de KL wel regel. matig modische beperkingen op grond van aandoeningen die op de groene kaart zijn vermeld. In die zin zijn keurend artsen bij het gebruik maken van curatieve gegevens wel degelijk gewend om 'vanaf het papier' te werken. Een tweede argument dat men tegen dit onderzoek zou kunnen aanvoeren is dat de keurend artsen op deze wijze wellicht te weinig informatie tot hun beschikking hebben gehad. Als dat juist zou zijn, dan zou de afdeling GA jarenlang verstrkkende consequenties hebben verbonden op basis van gebrekkige informatie.

De ABOHZIS-classificatie wordt in theoric aangevuld met de 'Aanwijzingen'; dit systeem zou ertoe mocten leiden dat bij soortgclijke keuringsbevindingen telkens eenzelfde ABOHZIS-classificatie wordt opgemaakt. De toegekende A, B en O-classificatie wordt in dit onderzoek in alle gevallen zonder wijziging door de afdeling GA overgenomen. In het vervolgtraject wordt op gecn enkele wijze van de ABOHZIS-gegevens gebruik gemaakt.

Alhoewel de overeenkomsten tussen de artsen niet altijd als 'slecht' kunnen worden gedefinicerd, sluit de gevonden uitslag aan bij eerdere publikaties over de tekortkomingen van het systeem.

De overeenkomst tussen de toegekende ABOHZIS-classificatie en de vastgestelde medische beperkingen is niet zo groot als wenselijk is: vaker worden geen medische beperkingen vermeld terwijl bij de rubrieken A, B en O een score anders dan 1 wordt toegekend.

Daar waar een logische relatic zou kunnen liggen tussen keuringsbevindingen en de $\mathrm{A}-$, $\mathrm{B}$ - of O-classificatie, is dit niet het geval bij de vaststilling van medische beperkingen. Er is geen voorschrift of aanwijzing bij welke aandoening men wat voor medische beperkingen dient te hanteren.

Bij de medische beperkingen is de overeenstemming tussen de artsen hoger dan bij het ABOHZIS-classificatiesysteem, maar niet statistisch significant. Dat is opmerkelijk want de ABOHZIS is praktisch voorgeschreven middels de 'Aanwijzingen'. Het protocolleren (ABOHZIS wel en de medische beperkingen niet) levert onder deze omstandigheden geen aantoonbaar verhoogde kwaliteit op.

De artsen zijn het eens over de PGO's waar oorspronkelijk geen beperkingen werden vasigesteld. Het feit dat keurend artsen onderling weinig beoordelingsverschillen vertonen indien zij een militair zonder afwijkingen keuren, zal geen verbazing wekken. Maar klaarblijkelijk nemen de onderlinge verschillen toe naarmate de medische problematiek groter is.

In tegenstelling tot de geringe praktische betekenis van de ABOHZIS-classificatie wordt er door de KL grote betekenis toegekend aan de medische beperkingen. Zij vormen de basis voor de functioneringsbeperkingen en kunnen aanleiding zijn om een militair geen nieuwe functie toe te wijzen, met als gevolg dat betrokkene sterk verlaagde kansen heeft op behoud van zijn werk.

Er treedt een zekere vervuiling in het systeem op. Ofschoon 'dispensatie' door de BLS als ongewenst is aangeduid, wordt hier toch in sommige gevallen nog een pleidooi voor gehouden. Geen van de oorspronkelijk vastgestelde X-scores leidde overigens tot onderzoek naar de dienstgeschiktheid. Er wordt met name rekening gehouden met factoren als leeftijd en wapen/dienstvak bij de verstrekking van medische beperkingen.

Tijdens dit onderzoek zijn vragen gerezen inzake de aard en inhoud van de gehanteerde lijst met medische beperkingen. Gezien de waarde die de KL hieraan hecht lijkt het van het hoog-

\section{Keuren is Mensenwerk}


ste belang juist het gebruik hiervan te protocolleren. Gelet op het teleurstellende resultaat van de protocollering van de ABOHZIS-classificatie fie immers geen betere overeenstemming oplevert dan de ongeprotocolleerde medische beperkingen) heeft een dergelijke protocollering echter alleen zin indien die medische beperkingen functie(groep)gericht zijn en kunnen worden afgezet tegenover functie-eisen.

Op grond van het bovenstaande kan worden geconcludeerd dat de ABOHZIS-systematiek, waarvan de nadelen al langer bekend zijn, zelfs met behulp van de 'Aanwijzingen', niet langer aan de huidige behoeften voldoet.

\section{Samenvatting}

In het onderzoek is gebleken dat keuringsuitslagen tussen individuele keurend artsen onvoldoende reproduceerbaar zijn. De keuringsuitslag is derhalve niet alleen afhankelijk van de status praesens en de groene kaart van de militair, maar ook van het inzicht van de keurend arts. Deze beschikt over te weinig geprotocolleerde informatie om aan dit gegeven verandering te kunnen aanbrengen.

Het gebruik van de ABOHZIS-classificatie levert geen meerwaarde op bij het periodieke onderzoek naar de dienstgeschiktheid van de individuele militair. Aangezien al bekend was dat dit instrument niet voldoende functiegericht is, zijn er geen redenen om de ABOHZISclassificatie nog langer te gebruiken.

\section{Summary}

In order to establish whether the results of the periodical physical examination, as performed in the Royal Netherlands Army, are reproducible, 24 cases were anonimised and two physicians were asked to fill in the PUHELMS score (A system originally adopted from the U.S. Army in 1946) of the findings and to advise which medical impairments they would choose. The inter-observer agreement between the two physicians and the original investigator on the PUHELMS classification and on the medical impairments appears not to be high.

Furthermore, the relation between the PUHELMS score and the medical impairments is too weak. The authors conclude that in the system in use with the Royal Netherlands Army the results of these physical examinations cannot easily be reproduced and that there are no reasons to continue to use the PUHELMS system. 


\section{Literatuur}

1 Raad J de, Blankestijn CDA. Loopbaanprognose bij de Koninklijke Landmacht: medische beperkingen. Carré 1995;7/8:10-3, Carré 1995:9:14-6, Carré 1995:10:20-4.

2 Militair Keuringsreglement. Staatsblad 1949, J, 404; Staatblad 1960, 370; Staatsblad 1968, 455, en laatst herzien t.a.v. de bijlage in Staatsblad 1986, 335.

3 Ministerie van Defensie. Aanwijzingen voor artsen belast met militaire keuringen. Inclusief: Militair Keuringsreglement 1986 met bijlage. Herziene uitgave Ministeriële Publicatic MP 35-401. Tweede druk, laatst herzien in november 1995. Den Haag, 1987.

4 Werkverband Medische Eisen KL. Personeel. Rapportage. Den Haag: Ministerie van Defensie, 1994. 5 Ministerie van Defensie. Procedure Geneeskundig/Tandheelkundig Onderzock. Rechtspositie militairen, Algemene maatregelen van bestuur, MP 31-109-3, 3210. Derde druk laatst herzien in 1994. Den Haag, 1966.

6 Ministerie van Defensie. Rechtspositie militairen, Algemene maatregelen van bestuur. MP 31-109-1. Derde druk laatst herzien in 1994. Den Haag, 1966.

7 Ministerie van Defensie. Besluit Procedure Geneeskundig Onderzoek Militairen, BPGOM. Rechtspositie militairen gezondheidszorg. MP 31-101/1170. Derde druk laatst herzien in november 1995. Den Haag, 1990.

8 Querido RA. Het rust-electrocardiogram bij periodiek geneeskundig onderzoek. Scriptie geïntegreerde opleiding bedrijfsgeneeskunde. Leiden: NIPG/TNO, 1990.

9 Kessel JGFM van. Consequenties van onjuist keuren. Nederlands Militair Geneeskundig Tijdschrift 1984:37:176-193.

10 Belloni R. De bepaling van de dienstgeschiktheid: een studie naar de bepaling van de diensigeschiktheid bij de Koninklijke Landmacht, in het bijzonder van de beroepsmilitair met een verbintenis voor onbepaalde tijd. Scriptie in het kader van de opleiding verzekeringsgeneeskunde. Utrecht: Stichting voor Sociale Gezondheidszorg, 1983.

11 Jansen J, Lourijsen ECMP, e.a. Een verkenning van voorspellend onderzoek in keuringssituaties. Bilthoven: RIVM, 1993.

12 Commissie Medische Keuringen. Keuren en voorspellen. Den Haag: Gezondheidsraad, 1993.

13 Lourijsen ECMP, Kort WLAM de, Dam J. De praktijk van de medische aanstellingskeuring in Nederland. Fen samenvattend verslag van eeñ aantal onderzoeken naar de omvang, uitvoering en kwaliteit van medische aanstellingskeuringen. Den Haag: Ministerie van Sociale Zaken en Werkgelegenheid, 1991 .

14 Schouten HJA. Nominal Scale Agreement among Observers. Psychometrika 1986;51:453-66.

15 Schouten HJA. Klinische statistick. Houten: Bohn Staffleu Van Loghum, 1995. 


\section{BESCHOUWING}

In dit hoofdstuk worden de belangrijkste bevindingen van het onderzoek besproken. Daarbij wordt nagegaan in hoeverre de onderzoeksvragen zijn beantwoord. Vervolgens worden de methodologische beperkingen behandeld. Ook wordt ingegaan op de bruikbaarheid van dienstplichtgegevens voor andere doeleinden dan waarvoor zij primair zijn bedoeld. Daarna worden aanbevelingen gedaan voor verbeteringen van het keuringsapparaat en voor verder onderzoek.

\subsection{Belangrijkste bevindingen}

Sinds de invoering van de dienstplicht is er behoefie aan medische dienstplichtkeuringen. Het werd bijvoorbeeld van belang geacht dat een persoon zijn rechteroog niet miste, zodat hij in staat was zijn tegenstander met een 'karabijn' te raken. In de loop der tijd is de keuring uitgegroeid tot een complexe beoordeling van de medische gezondheidstoestand van de persoon in kwestie. De medische eisen zijn vastgelegd in het Militair Keuringsreglement (MKR). Op deze wijze is getracht de keuring zo uniform mogelijk te laten verlopen.Desondanks is niet bekend of dit leidt tot reproduceerbare keuringsuitspraken. Ook is onbekend of de voorspellende waarde voldoende is. Derhalve is besloten onderzoek te verrichten naar de kwaliteit van de medische keuring. Dit is gedaan aan de hand van de volgende onderzoeksvragen:

- In hoeverre is het mogelijk het medisch disfunctioneren in militaire dienst te voorspellen?

- In welke mate zijn militiare keuringen reproduceerbaar?

Dit onderzoek is uitgevoerd binnen de Nederlandse krijgsmacht en met bijzondere aandacht voor de dienstplicht. Immers, ter beantwoording van deze vraagstellingen zijn gegevens van de dienstplichtkeuringen en ten dele gegevens van de medische keuringen voor beroepsmilitairen gebruikı.

\section{Medisch disfunctioneren}

De mate warin dienstplichtigen tijclens het vervullen van de militaire dienst medisch disfunclioneren zegt iets over de negatieve voorspellende warde van de keuring.

Aangezien over de afgekeurden nict bekend is of zij terecht of onterecht zijn afgekeurd, kan geen inzicht worden verkregen in de positieve voorspellende warde van de keuring. Op de positicve voorspellende waarde wordt derhalve niet verder ingegaan.

De negatieve voorspellende waarde wordt berekend aan de hand van het aantal personen dat terecht blijkt te zijn goedgekeurd en het aantal dat onterecht blijkt te zijn goedgekeurd.

Indien men tijdens de keuring iedereen detecteert die tijdens de militaire dienst om medische redenen niet zal blijken te functioneren, is de negatieve voorspellende waarde maximaal. Ter bevordering van de leesbaarheid wordt in de tekst de negatieve voorspellende waarde aangeduid met voorspellende warde.

Gebleken is dat tussen de $6 \%$ en de $8 \%$ van de dienstplichtigen die bij de Koninklijke Landmach zijn opgekomen, om medische redenen disfunctioneert. De meerderheid $(75 \%)$ van de 
disfunctioneerders wordt afgekeurd wegens onvoldoende psychische stabiliteit (de S-rubriek van het ABOHZIS-classificatiesysteem) of aandoeningen van de onderste extremiteiten en de rug (de O-rubriek).

Men kan zich nu afvragen of dit percentage medisch disfunctioneerders hoog is.

Om dit te kunnen beoordelen, is het zinnig het percentage te vergelijken met het percentage disfunctioneerders bij andere Nederlandse krijgsmachıdelen, bij de krijgsmachtdelen in andere landen en in de burgermaatschappij.

In Nederland heeft Lamberts ' met betrekking tot de voorspelling van stabiliteit bij dienstplichtigen een poging ondernomen om het percentage personen dat door psychische problemen niet functioneert te vergelijken. Hij komt tot de conclusie dat in de periode 1958-1967 niet alleen het aantal afkeuringen vóór opkomst is toegenomen, maar ook het aantal afkeuringen tijdens het vervullen van de militaire dienst (van $7 \%$ tot $14 \%$ ). De meeste disfunctionerende dienstplichtigen zijn op de S- en O-rubriek afgekeurd.

Uit gegevens van het medische informatiesysteem van het Ministerie van Defensie blijkt tussen 1986 en 1991 gemiddeld $7 \%$ bij de KL te disfunctioneren.

- In $1986^{2}$ is het medisch disfunctioneren van dienstplichtigen bij de Koninklijke Luchtmacht (KLU) onderzocht. Bij de KLU is in de periode van 1979 tot en met 1983 gemiddeld $7,5 \%$ afgekeurd na opkomst. De meeste afkeuringen zijn gebaseerd op afwijkingen van het gehoor en van de psychische stabiliteit ( $32 \%$ respectievelijk $47 \%$ ), gevolgd door aandoeningen van de onderste ledematen (12\%) en de algemene conditie $(8 \%)$. In die periode werd hel gehoor van dienstplichtigen tijdens de eerste keuring getest door middel van fluisterspraak en in dienst getest via een audiomaat, hetgeen het hoge afkeuringspercentage verklaant. Als deze afkeuringen op de $\mathrm{H}$-rubriek buiten beschouwing worden weggelaten, is de uitval van dienstplichtigen bij de KLU lager dan bij de KL. Echter bij de KLU komen alleen diensiplichtigen zonder enige beperking in aanmerking, terwijl bij de KL ook dienstplichtigen met beperkingen in dienst komen.

Over het medisch disfunctioneren van dienstplichtigen in andere landen is weinig bekend. Het percentage medische disfunctioneerders ten opzichte van België en Zweden is hoog, maar gegevens over de aanwezigheid van mogelijkheden om tijdens dienst te worden afgekeurd ontbreken, zodat vergelijking moeilijk is '.

Volgens gegevens verkregen via de Franse ambassade heeft Frankrijk meer disfunctioneerders dan Nederland. Echter de procedure voor opkomst is anders dan in Nederland. In Frankrijk wordt voor opkomst een hoger percentage goedgekeurd. Een hogere uitval tijdens dienst is daardoor niet onverwacht.

Ook moet worden bedacht dat dienstplichtigen in andere landen onder andere omstandigheden functioneren. In Israël vervullen mannen en vrouwen van 18 jaar respectievelijk 3 en 2 jaar hun dienst. Daarna zijn zij tot 55 jaar oproepbaar om in actieve dienst te dienen.

Zij worden daadwerkelijk blootgesteld aan oorlogsactiviteiten :

Wat betreft beroepsmilitairen is in Nederland een onderzoek gedaan naar het opleidingsverloop van Beroepsmilitairen met een verbintenis voor Bepaalde Tijd (BBT"ers) van het Schoolbataljon Luchtmobiele Brigade. Gebleken is dat een vrij hoog percentage vroegtijudig 
afhaakt. In tegenstelling tot de overige schoolbataljons is het verloop $37 \%$ in plaats van gemiddeld $14 \%$ bij de andere schoolbataljons: Dit verloop is niet alleen toe te schrijven aan medische redenen, maar voornamelijk aan psycho-sociale redenen. De belangrijkste redenen zijn: zich niet thuisvoelen bij de Luchtmobiele Brigade (18\%), opleiding anders dan men zich had voorgesteld $(17 \%)$, medische redenen (16\%) en fysieke belasting $(12 \%)^{3}$. In verhouding tot de opleiding van BBT'ers bij de schoolbataljons is het verloop om medische redenen bij dienstplichtigen laag.

Bij de vergelijking met het medisch disfunctioneren bij beroepsmilitairen moet tevens in ogenschouw worden genomen dat een beroepsmilitair, in tegenstelling tot een dienstplichtig militair, de functie vrijwillig aanvaardt. In Nederland hebben dienstplichtigen die eenmaal in dienst zitten, slechts twee mogelijkheden om de dienst vroegtijdig te verlaten. Ze kunnen om medische redenen worden afgekeurd of om psycho-sociale problemen via een DINIMED-procedure (DINIMED=DIsfunctioneren om NIet MEDische redenen) buitengewoon dienstplichtig worden verklaard. Beroepsmilitairen, daarentegen, kumnen ontslag nemen.

Voorts moet men bedenken dat de selectie voor beroepsmilitairen veel uitgebreider is dan voor dienstplichtigen. Naast de medische keuring ondergaan aspirant-beroepsmilitairen ook een psychologisch onderzoek en een conditietest.

Op internationaal niveau zijn geen gegevens vergelijkbaar. Wel is onderzoek verricht naar bepaalde aspecten, maar door de specifieke omstandigheden zijn de uitkomsten niet vergelijkbaar.

In het burgerleven komen mensen die om medische redenen niet functioneren eerst in de Ziektewet en een deel daarvan vervolgens in de WAO (=Wet op de ArbeidsOngeschiktheidsverzekering). Na de invoering van de WAO is het aantal arbeidsongeschikten snel gegroeid, waarbij vanaf de jaren tachtig het aantal uitkeringsgerechtigden relatief stabiel is gebleven. Het percentage is vanaf 1970 gestegen van $6 \%$ tot $13 \%$ in 1992 . Ook hier is arbeidsongeschiktheid voornamelijk het gevolg van psychische klachten en klachten van het bewegingsapparaat $*$.

Hoewel een percentage medisch disfunctioneren van $6 \%$ tot $8 \%$ op zich niet erg hoog lijkt. geeft het voldoende aanleiding om te onderzoeken welke mogelijkheden aanwezig zijn om het disfunctioneren te verminderen. In absolute aantallen gat het om meer dan 2.400 personen (van een groep bestaande uit \pm 40.000 dienstplichtigen die bij KL zijn opgekomen). De dienstplichtigen komen niet vrijwillig in dienst. Het Ministerie van Defensie dient extra zorg te dragen voor de beperking van de nadelige gevolgen van de dienstplichtvervulling.

A،ngezicu de dald van het disfunctioneren verschillend kan zijn, zijn de prognostische factoren ap.rr voor het disfuncrioneren op de O-rubriek en op de S-ruhrick onderzocht.

De afkeuringsprocedure is zodanig dat alleen de belangrijkste afkeuringsreden wordt vermeld. Derhalve is bij de onderzoekspopulatie geen overlap van afkeuringsredenen wat betreft de O- en S-rubriek aanwezig.

Aan de hand van de resultaten zijn risicoprofielen vastgesteld. Berekend is in hoeverre het medisch disfunctioneren zou verminderen als de dienstplichtigen die voldoen aan het risicoprofiel niei de militaire dienst hoefden te vervullen. Als degenen met een verhoogd risico niet in dienst zouden zijn gekomen, zou voorkomen zijn dat 37 dienstplichtigen zouden disfunctio- 
neren: 36 van de 235 disfunctioneerders wegens aandoeningen van de onderste extremiteiten en de rug én l van 281 dislunctioneerders als gevolg van onvoldoende psychische stabiliteit.

In welke mate wordt de voorspellende waarde verhoogd als op basis van de risico-profielen een strenger afkappunt wordt gehanteerd bij de keuring ?

Volgens de gegevens van het cohortonderzoek naar het medisch disfunctioneren is de voorspellende waarde van de medische dienstplichtkeuring $91,9 \%$. Immers in eerste instantie bleken 705 van de 8714 dienstplichtigen te disfunctioneren.

Selectie aan de hand van het risicoprofiel van medisch disfunctioneren van de S-rubriek heeft het minimale effect dat 1 persoon minder disfunctioneert. De voorspellende waarde blijft derhalve $91,9 \%$.

Om het aantal personen dat door aandoeningen van de onderste extremiteiten en de rug niet functioneert in dienst, te verminderen, kan een extra schifting - aan de hand van de risicoprofielen - het aantal medische disfunctioneerders verlagen tot 669. Als naast de keuring ook wordt geselecteerd aan de hand van de risicoprofielen, wordt de voorspellende waarde verhoogd tot $92,3 \%$.

Een verzwaring van de selectieeisen op grond van de gepresenteerde risicoprofielen leidt tot een geringe verhoging van de voorspellende waarde. Geconcludeerd kan worden dat het kiezen van een strenger afkappunt ontoereikend is om het disfunctioneren wegens psychische stoornissen te voorkomen, maar het verzwaren van de selectie-eisen ten aanzien van de onderste ledematen en de rug een overweging waard is.

\section{Reproduceerbaarheid}

Allereerst blijkt aan de hand van gegevens van de eerste dienstplichtkeuringen van 1993 dat zowel tussen de indelingsraden als tussen de artsen variatie in de keuringsuitslag aanwezig is Bij afkeuringen op grond van aandoeningen van de onderste extremiteiten en de rug is de grootste variatie waarnecmbaar, maar deze is ook bij de afkeuringsrubrieken A-, H-, Z- en Srubrieken van de ABOHZIS aanwezig. De variatie is deels te verklaren door procedureverschillen tussen de indelingsraden bij onvoldoende gehoor- of gezichtsvermogen. De resterende inter-raadvariatie is het gevolg van verschillen tussen de individucle artsen, hetgeen wordt veroorzaakt door verschillen in het besluitvormingsproces.

Met behulp van schriftelijke dossiers is de overeenkomst tussen de artsen bij zowel dienstplichtkeuringen als Periodieke Geneeskundige Onderzoeken (PGO's) voor beroepsmilitairen van de Koninklijke Landmacht vastgesteld.

De overeenkomst bij dienstplichtkeuringen is nagegaan door zesendertig artsen de geschiktheid voor militaire dienst bij 14 'moeilijk beoordeclbare' casussen (met betrekking tot aandoeningen van de onderste extremiteiten en de rug) te laten beoordelen. De besluitvorming wordt bemoeilijkt ondat de aard en de ernst van de aandoeningen niet eenduidig zijn vast $t c$ stellen en/of het Militair Keuringsreglement (MKR) en het Aanwijzingenboek, bestemd voor de keurend artsen, geen eenduidige instructic bevatuen over de te geven beoordeling. 
De arts heeft daardoor een grote beslissingsruimte. Hij/zij bepaalt zelf welke factoren in de beslissing worden meegenomen en hoe zwaar deze factoren wegen.

Voor zowel de keuringsuitslag als de beoordeling van de beperkingen ten aanzien van onderste extremiteiten en de rug (de O-rubriek) blijkt dat de overeenstemming tussen de keurend artsen laag is: de Cohen's kappa bedraagt respectievelijk 0.20 en 0.17. De invloed vanuit de indelingsraad op de overeenstemming is niet groot. Bij geen enkele indelingsraad is de kappa die de overeenkomst tussen de artsen binnen één indelingsraad weergeeft, hoger dan 0.40. Contextuele informatie lijkt de overeenstemming tussen artsen te verlagen. Deze informatie speeit wellicht een belangrijke rol bij beoordelingen waar de beslissingsruimte binnen het besluitvormingsproces groot is.

De overeenkomst tussen artsen die Periodiek Geneeskundige Onderzoek (PGO's) verrichten bij het beroepspersoneel van de Koninklijke Landmacht is nagegaan aan de hand van 24 aselect gekozen casussen. Deze zijn voorgelegd aan 2 artsen. De overeenkomst tussen beoordelingen van de oorspronkelijke arts en de beoordelingen van de twee andere artsen is eveneens berekend met Cohen's kappa. Bij deze keuringen zijn niet alleen de beoordeling ten aanzien van de $\mathrm{A}$-, $\mathrm{B}$ - en $\mathrm{O}$ - rubriek vastgelegd, maar ook de medische beperkingen. Wat betreft de keuringsuitslag is de overeenstemming slecht (voor de A-rubriek) tot redelijk (voor de Ben O-rubriek). Bij het wel of niet toekennen van de medisch beperkingen is de overeenstemming redelijk. Ook in dit onderzoek is de overeenkomst tussen de individuele keurend artsen niet zo hoog als wenselijk wat betreft de keuringsuitslagen; zeker ten aanzien van de beoordeling van de O-rubriek. 


\subsection{Kritische kanttekeningen}

In 1992 is dit onderzoek gestart onder het project 'Relatie Defensiekeuringen' binnen de Directie Dienstplichtzaken. De opzet was om, door meer inzicht te krijgen in keuringen van dienstplichtigen, feedback te kunnen geven aan de keurend artsen. Pas tijdens het onderzoek is bekend geworden dat de opkomstplicht per l januari 1997 zou worden opgeschort en inmiddels zijn de laatste dienstplichtigen in augustus 1996 vertrokken. Besloten is om het onderzoek toch te continueren. Belangrijk argument hiervoor is dat de eisen bij dienstplichtkeuringen gelijk zijn aan de basiseisen van alle militaire keuringen. Ondanks de opschorting van de opkomstplicht blijven de keuringseisen en procedures gehandhaafd. De resultaten van dit onderzoek zijn daardoor ook relevant voor de andere militaire keuringen.

Voorts kan men stellen dat de dienstplichtkeuring een bijzondere vorm van een aanstellingskeuring is en dat aanstellingskeuringen alleen bij die functies dienen te worden verricht, warbij de veiligheid en de gezondheid van de persoon in kwestie of derden in gevaar kunnen worden gebracht ". Dit geldt uiteraard voor militaire functies, waardoor aanstellingskeuringen voor militaire functies onontkoombaar zijn. Derhalve dient onderzoek te worden verricht naar de kwaliteit van deze keuringen.

Hoewel het niet mogelijk was een volledig overzicht van de kwaliteit van militaire keuringen te geven, zijn belangrijke kwaliteitsaspecten van de keuring onderzocht. Het onderzoek is toegespitst op de validiteit en de reproduceerbaarheid van de keuring. De onderstaande beperkingen spelen hierbij een rol.

Er is geen totaal beeld verkregen van de keuringen binnen de gehele krijgsmacht. Het onderzoek betreft voor het grootste deel dienstplichtkeuringen en voor een klein deel keuringen voor beroepsmilitairen van de Koninklijke Landmacht: het medisch disfunctioneren is onderzocht aan de hand van dienstplichtgegevens. Bij het onderzoek naar de reproduceerbaarheid zijn zowel dienstplichtgegevens als de gegevens van keuringen van de vrijwillig dicncnde militairen van de Koninklijke Landmacht gebruikt.

De beschikbare gegevens zijn niet toereikend om alle aspecten van de kwaliteit te meten. Gegevens over de ongeschikt verklaarden ontbreken, waardoor niet kan worden nagegaan welk deel van de keurlingen ten onrechte is afgekeurd. Diverse methoden zijn overwogen om een schatting te maken van het percentage daadwerkelijk geschikten van de grocp afgekeurde dienstplichtigen. Afgekeurden zouden benaderd kunnen worden via een enquête. Aan de hand van vragen over de werkzaamheden van de huidige functie en sportactiviteiten, kan men proberen het lichamelijke en geestelijke functieniveau na te gaan. Deze optie levert echter veel interpretatieproblemen op. Ten eerste is het niet ondenkbaar dat de geënquêteerden het formulier helemaal niet of niet naar waarheid invullen, omdat zij bang zijn voor mogelijke represailles. En als de vragen wel betrouwbaar worden beantwoord, kan men zich afvragen of de uirkomsten vergeleken kunnen worden met de resultaten van de dienstplichtkeuring. De aard van de werkzaamheden (als burger) is namelijk niet alleen afhankelijk van de lichamelijke en geestelijke gesteldheid van de persoon, maar ook van de genoten opleiding en werkervaring. Een alternatief zou een herkeuring zijn. Het nadeel hiervan is dat er sprake kan zijn van een selectiebias, aangezien dit alleen op basis van vrijwilligheid kan geschieden.

\section{Keuren is Mensenwerk}


De resultaten zijn voornamelijk gebaseerd op aanwezige gegevens. Het onderzoek naar het medisch disfunctioneren betreft immers een retrospectief cohortonderzoek. Een nadeel hiervan is dat bepaalde gegevens, die wel van invloed kunnen zijn op het medische disfunctioneren maar niet worden geregistreerd, niet te achterhalen zijn. Daartegenover staat als voordeel dat op korte termijn gegevens over een grote groep bekend zijn.

Ten behoeve van het vaststellen van de reproduceerbaarheid zijn de beschikbare gegevens gebruikt om de mate van variatie in kaart te brengen. Om de daadwerkelijke overeenkomst ussen de artsen vast te stellen was het noodzakelijk de benodigde gegevens op een andere wijze te verzamelen, namelijk met behulp van experimenten. Bij experimenten, die zijn uitgevoerd om de inter-doktervariatie vast te stellen, is gebruik gemaakt van schriftelijke dossiers. De vraag kan worden gesteld of de besluitvorming bij schriftelijke casuïstiek representatief is voor de besluitvorming van de keurend arts in de praktijk ${ }^{10}$. Vooralsnog wordt betekenis gegeven aan de uitkomsten van dit onderzoek, omdat de casuïstiek ontleend is aan de praktijk.

Bij het onderzoek naar de overeenkomst bij dienstplichtkeuringen zijn alleen moeilijk beoordeelbare gevallen aan de artsen voorgelegd. Te verwachten is dat vooral bij moeilijke casussen de reproduceerbaarheidsproblemen zich zullen voordoen. Met 'moeilijk' wordt bedoeld dat niet alleen objectief vast te stellen aandoeningen een rol spelen bij het besluitvormingsproces. Alhoewel hieromtrent nauwelijks literatuur aanwezig is, wordt de geschiktheidsbeoordeling beschouwd als het resultaat van een wegingsproces van objectief meetbare kenmerken en subjectieve (en derhalve niet (goed) meetbare) informatie. Dit wegingsproces blijkt niet goed voor onderzoek toegankelijk te zijn ${ }^{11.1213}$. Ook in het onderhavige onderzoek is geen volledig inzicht verkregen in dit proces. Echter, een aantal zaken kunnen worden opgemerkt.

Het bepalen van de dienstgeschiktheid bij militaire keuringen is een wegingsproces waarbij allereerst de aard en de ernst van aandoeningen moeten worden bepaald en daarna de beoordeling van geschiktheid. Moeilijkheden doen zich niet alleen voor als de aandoeningen niet objectief zijn vast te stellen, maar ook als het MKR en het Aanwijzingenboek de arts de ruimte geven voor een eigen interpretatie. In zo'n geval kan de arts zelf bepalen in hoeverre hij/zij contextuele informatic meeneemt in zijn beslissing en welk gewicht hieraan wordt gegeven. De individuele arts heeft daardoor een grote beslissingsruimte. Lourijsen en Dam " constateren dat er bij aanstellingskeuringen verschillen zijn tussen artsen in interpretatie van gelijkluidende medische gegevens en de belangrijkheid die men toekent aan de beoordelingsaspecten. Alhoewel het MKR en het Aanwijzingenboek richtlijnen en criteria bieden, blijf deze beslissingsruimte in min of meerdere mate aanwezig.

Tot nu toe hebben we het alleen gehad over de beslissingsruimte van de arts. Ook de keurling heeft een zekere beslissingsvrijheid. Hij heeft de mogelijkheid om bepaalde klachten en bijbehorend (vermeend) ziektegedrag al dan niet te presenteren dan wel te benadrukken.

Het verloop van een ziektegeval kan in navolging van Philipsen ${ }^{14}$ worden geschouwd als een besliskundig oordeel. De beslissingsvrijheid van betrokkene om ziektegedrag te vertonen is bij 'niet ernstige objectieve-subjectieve aandoeningen' groter dan bij 'acute zeer emstige objectieve aandoeningen'. De wens om niet te worden opgenomen in het leger als dienstplichtig militair, zou kunnen meespelen bij de afweging van de keurling om te kiezen voor een specifiek (ziekie)gedrag. 
Door de selectie van de casussen bij het eerste experiment wordi geen representatieve indruk. gegeven van het totale aanbod van dienstplichtkeuringen. Om deze reden zijn tijdens het tweede experiment aselect gekozen PGO's gebruikt. De PGO's dienen als voorbeeld van keuringen van beroepsmilitairen. Ook hier is de overeenstemming tussen de artsen niet hoog.

\section{Tenslotte moet de vraag worden gesteld of er mogelijkheden aanwezig zijn om de voorspellende waarde en de reproduceerbaarheid van de militaire keuring te verhogen.}

\section{Voorspellende waarde}

Wat betreft de voorspellende waarde kan worden geconcludeerd dat het overgrote deel $(91,9 \%)$ van de dienstplichtigen, die ook werkelijk in dienst zijn geweest, terecht geschikt is verklaard. Prognostische factoren kunnen het medisch disfunctioneren voor een deel voorspellen. Door het uitsluiten van dienstplichtigen met een verhoogd risico kan het aantal medische disfunctioneerders worden verminderd, maar niet in die mate dat de voorspellende waarde aanzienlijk wordt verhoogd.

In tegenstelling tot het disfunctioneren op de S-rubrick, is bij het disfunctioneren op de $\mathrm{O}$ rubriek het verhogen van de voorspellende waarde, door middel van een extra selectie via risicoprofielen, een overweging waard.

Voordat men echter besluit tot een strenger keuringsbeleid ten aanzien van de O-rubrick, moeten de hiermee verbonden kosten en baten tegen elkaar worden afgewogen.

Een strenger afkappunt heeft tot gevolg dat het aantal onterecht goedgekeurden afneemt, maar het aantal onterecht afgekeurden zal toenemen.

De kosten van het aannemen van een ongeschikte kandidaat bevatten de posten: werving, keuring en training ${ }^{15}$. Aan dienstplichtigen zijn geen wervingskosten verbonden. Wel moet rekening worden gehouden met de kosten van arbeidsongeschiktheid ten gevolge van militaire dienst. Arbeidsongeschiktheid betekent voor de persoon zelf niet alleen materiële schade, maar ook persoonlijk leed. De kosten die samenhangen met het afwijzen van een geschikte kandidaat zijn de 'opportunity costs' van een productief persoon in de krijgsmacht ${ }^{\text {s. }}$. Het is niet mogelijk gebleken de omvang en de persoonlijke gevolgen van een onterechte afkeuring te onderzoeken. Denkbaar is dat mannen voor een functie in de burgermaatschappij worden afgewezen, omdat zij ongeschikt zijn bevonden voor militaire dienst.

De 'opportunity costs' die samenhangen met het afkeuren van een geschikte persoon zijn in een dienstplichtig leger nagenoeg verwaarloosbaar, omdat het aanbod zo groot is dat altijd een alternatief individu klaar staat om in dienst te komen.

De gevolgen van het in dienst laten komen van ongeschikte diensiplichtigen zijn kostbaar en kunnen door selectie worden geminimaliseerd ${ }^{15}$.

Een juiste afweging te maken is niet eenvoudig, aangezien naast financiële gevolgen voor de werkgever, ook materiële en immateriële schade voor de dienstplichtigen kunnen meespelen. Men zou kunnen stellen dat door het overschot aan dienstplichtigen, de nadelen van de onterechte afkeuring niet opwegen tegen de nadelen van de onterechte goedkeuring. Iedere bijdrage aan het verbeteren van de voorspellende waarde zal het selectic-instrument valider maken. Een van de uitkomsten van het onderzoek is het reduceren van medisch disfunctioneren wegens aandoeningen van de onderste extremiteiten inclusief de rug door het gebruik van verzwaarde selectie-eisen. 
Wat betreft het disfunctioneren wegens onvoldoende psychische stabiliteit blijkt een strengere keuring geen bijdrage te leveren. Dat is deels te verklaren door het gevoerde beleid.

Dienstplichtigen met een beperking op de S-rubriek (een S3 of een S2 in combinatie met een 12) worden voor opkomst buitengewoon dienstplichtig verklaard.

Dienstplichtigen met psycho-sociale problemen kunnen, naast een afkeuring, ook de dienst vroegtijdig verlaten als buitengewoon dienstplichtigen (via de DINIMED-procedure). Jaarlijks betreft dit $7,7 \%$ van de opgekomen dienstplichtigen van de KL. Dit type disfunctioneren is onderzocht door de afdeling Gedragswetenschappen van de Koninklijke Landmacht ${ }^{16}$.

Deze groep disfunctioneerders wordt dus niet via het medische keuringstraject getraceerd. Te veronderstellen valt dat de grens tussen een alkeuring op de S-rubriek en een buitengewoon dienstplichtig-verklaring via de DINIMED-procedure niet altijd even scherp te trekken is. Wellicht hadden dienstplichtigen die via de DINIMED-procedure de militaire dienst hebben verlaten, dit ook via cen atkeuring op de S-rubriek de dienst kunnen doen. Het disfunctioneren wogeus psychische problemen is derhalve aanzienlijk groter dan uit de medische gegevens blijkt.

Het is aannemelijk dat de keuring, zoals die in het verleden bij dienstplichtigen is verricht, te kort schoot om psychische problemen vroegtijdig te herkennen.

In 1992 is psychologisch onderzoek toegevoegd aan de dienstplichtkeuring; niet voor iedere keurling, maar voor situaties waar problemen ten aanzien van de S-rubriek te verwachten zijn.

Bij het onderzoek naar het medisch disfunctioneren heeft de onderzockspopulatie nog geen psychologisch onderzoek tijdens de eerste dienstplichtkeuring (van 1989) ondergaan.

Het psychologisch onderzoek is een noodzakelijke aanvulling op de medische keuring, vooral als men wil nagaan of de persoon in een oorlogssituatie kan functioneren. Het onderzoek naar medisch disfunctioneren heeft betrekking op dienstplichtigen die hun plicht vervullen in vredestijd. Het risico op medisch disfunctioneren tijdens een oorlogssituatie is uiteraard veel groter. Derhalve zijn dienstplichtigen voor uitzending naar voormalig Joegoslavië onderworpen aan een extra medisch en psychologisch onderzoek. Het psychologisch onderzoek heeft tot doel potentiële aanpassingsproblemen op te sporen en zo onnodige slachtoffers te voorkomen ${ }^{17}$.

Al deze overwegingen gelden niet vanzelfsprekend voor het beroepsleger.

Om de voorspellende waarde van de keuring van de beroepsmilitairen vast te stellen dient apart onderzoek te worden gedaan, daarbij rekening houdende met specifieke factoren, zoals uitzendbaarheid. Door de veranderde taakstelling van het leger dient elke militair uitzendbaar te zijn.

Belangrijk verschil tussen een dienstplichtig leger en een beroepsleger is het verschil tussen vraag en aanbod.

In tegenstelling tot het aanbod dienstplichtigen is het aanbod beroepsmilitairen beperkt. De afweging van een onterechte afkeuring zal daarom bij een beroepsleger zwaarder wegen. 
De positie van de dienstplichtige is niet geheel vergelijkbaar met de positie van de sollicitant die een functie in het beroepsleger of in het bedrijfsleven ambieert. Dienstplichtkeuringen nemen een bijzondere positie in bij het aannamebeleid. Iedere Nederlandse man is verplicht om de militaire dienst te vervullen. Er is geen sprake van zelfselectie bij de dienstplichtkeuring. Dit in tegenstelling tot aanstellingskeuringen voor beroepsmilitairen en functies in de burgermaatschappij. Alleen indien de dienstplichtige niet kan voldoen aan de eisen van de dienstgeschiktheid, hoeft hij zijn plicht niet te vervullen (of indien hij buitengewoon dienstplichtig wordt verklaard of vrijstelling krijgt).

Pas als de behoefte van de krijgsmacht bekend is, wordt het grote aanbod geschiktverklaarden dienstplichtigen ingedeeld naar de vraag van te vervullen functies. Daarbij wordt gelet op de minimale ABOHZIS-eisen en eventueel opleidingseisen, die voor elke functie gelden. Deze indeling is een taak van het personeelsbeleid. Het besluit dat dienstplichtigen met een $\$ 2$ en I2 of S3 buitengewoon dienstplichtig worden verklaard is gebaseerd op vraag en aanbod. Het is van belang om een onderscheid te maken tussen de functie van de dienstplichtkeuring en de functie van de aanstellingskeuring. De aanstellingskeuring is geen selectie-instrument deze heeft dan ook plaats na de selectie - maar is gericht op de vraag of de belastbaarheid van de persoon aansluit op de functie-eisen. De dienstplichtkeuring is een selectie-instrument gericht op het onderscheiden van groepen die wel of niet in staat zijn om aan de eisen van de dienstplicht te voldoen.

De aanstellingskeuringen van beroepsmilitairen van alle krijgsmachtdelen worden in de toekomst centraal uitgevoerd. Volgens de richtlijnen van de Defensie-organisatie werving en selectie (DWS) dient het geneeskundig onderzoek voor $80 \%$ te bestaan uit het Basis Geneeskundig Onderzoek en voor $20 \%$ uit Specifiek Geneeskundig Onderzoek. Het Specifiek Geneeskundig Onderzoek bevat keuringselementen die betrekking hebben op specifieke functies. DWS speelt deels in op het functiegericht keuren. Zij stellen als randvoorwaarde dat de krijgsmachtdelen functie-eisen leveren. De voortgang is afhankelijk van het aanleveren van deze functie-eisenomschrijvingen.

Wanneer het Ministerie van Defensie zich in de toekomst nog meer richt op het functiegericht keuren, dient de vrij algemene omschrijving van dienstgeschiktheid in termen van functieeisen te worden herschreven. Daarnaast dienen voor alle functiegroepen specifieke functieeisen worden aangegeven. De kwaliteit van de functie-eisenomschrijving bepaalt daarmee ook de kwaliteit van de medische eisen voor die lunctiegroep.

De Swaan ${ }^{21}$ heeft aangegeven dat 'de medische expertise wordt uitgerekt voorbij de grenzen waarin ze nog geldig zijn'.

Dit zou met name kunnen gelden voor de S-rubriek. Wanneer we echter kijken naar het aannamebeleid van BBT'er blijkt dat het medisch domein eerder wordt ingeperkt dan uitgebreid. De medische keuring wordt voorafgegaan door psychologisch onderzoek. Alleen degenen die bij de psychologisch onderzoek niet afvallen, ondergaan een medische keuring.

Bij de aanstellingskeuringen die wegens medische functie-eisen noodzakelijk blijven, is medische expertise noodzakelijk om tot een goed oordeel te komen over de medische geschiktheid. Pas door het onderzoek van de Kort ${ }^{13}$ zijn de grenzen van de aanstellingskeuringen beter 
afgebakend. Hij adviseert geen aanstellingskeuring meer te verrichten tenzij gezondheids- en veiligheidsrisico aanwezig zijn. Bíj militaire functies speelt dit. Ook met dit onderhavige onderzoek en eventueel vervolgonderzoek worden de mogelijkheden om risico's zoveel mogelijk te beperken, duidelijker en dienen instrumenten met een voorspellende waarde verder te worden ontwikkeld. Dit zal bijdragen tot een nog betere afbakening van de mogelijkheden van aanstellingskeuringèn.

Het is niet haalbaar het aantal medisch disfunctioneerders zodanig te reduceren dat een voorspellende waarde van $100 \%$ wordt bereikt. De oorzaken van het medisch disfunctioneren kunnen van dien aard zijn dat zij vooraf niet te voorzien zijn. Militairen kunnen bijvoorbeeld een onvoorspelbare aandoening krijgen, waardoor zij tijdens het vervullen van de militaire dienst ongeschikt worden verklaard. Over het disfunctioneren als gevolg van ongevallen binnen of buiten de diensttijd is momenteel te weinig bekend om aan te geven of deze ongevallen voorkomen hadden kumnen worden. Sportblessures kunnen aanleiding zijn voor het disfunctioneren wegens aandoeningen van de onderste extremiteiten.

Echter, selectie is niet de enige remedie om de vourspellende waarde te verhogen.

Zoals Van Dijk en van der Weide ${ }^{18.14}$ aangeven, komt ouk bij een verscherpte selectic de meerderheid van de medische disfunctioneerders toch in dienst. Het personeelsbeleid moet derhalve niet alleen gericht zijn op het instroombelcid, maar dient ook andacht te besteden aan het begeleiden van personen in de organisatie. Dit behelst het nemen van preventieve maatregelen op de werkplek en het reintegreren van werknemers als middel ter voorkoming van medische disfunctioneren.

Wat betekent dit in de toekornst voor het Ministerie van Defensie?

Meer mogelijkheden moeten binnen het Ministerie van Defensie worden geboden om van functic te wisselen of werkaanpassingen te scheppen als blijkt dat door de functie te hoge eisen aan een persoon worden gesteld.

Daarbij moet rekening worden gehouden met het feit dat iedere militair in oorlogssituatie overal ter wereld inzetbaar moet zijn. De Bevelhebber der Landstrijdkrachten hecft aangegeven dat elke militair uitzendbaar moet zijn. Momenteel worden militairen voor een periode van 6 maanden uitgezonden. De militair moet in dusdanige (lichamelijke en geestelijke) conditie verkeren dat hij/zij in deze situatie moet kunnen functioneren. De persoon moet zowel in vredestijd (eventueel met adequate aanpassingen) als in uitzendperiode (waar aanpassingen vaak niet mogelijk zijn) de functie kunnen uitvoeren.

Een PGO is een middel om het functioneren op het medisch vlak te volgen, zeker bij beroepsmilitairen die een lange periode bij Defensie werken. Tot nu toe ondergaat iedere beroepsmilitair met een verbintenis voor onbepaalde tijd (BOT'er) om de 5 jaar een PGO. Normaal gesproken wisselt elke BOT'er volgens het functieroulatiesysteem periodiek (circa om de 3 jaar) van functie. Het is aan te bevelen de $\mathrm{PGO}$ vooral te laten gaan aan de functiewisseling, zodat problemen tijdens functie-uitvoering kunnen worden voorzien en tijdig kan worden ingegrepen. 
Het is de vraag in hoeverre problemen met betrekking tot de S-rubriek met behulp van preventieve maatregelen zijn te voorkomen. Gelet op de ervaringen mei de nieuwe taken van Defensie zou men nu beter in staat zijn te trainen op uitzendbaarheid of te selecteren op uitzendbaarheid en uitzendbereidheid.

Reïntegratie van werknemers kan bij militairen problemen opleveren. De situatie kan zich voordoen dat militairen bij een PGO medische beperkingen hebben gekregen. Zij voldoen daardoor niet meer aan de basiseisen van de militair of aan de eisen van een functie die volgens de carrièreplanning zou moeten worden vervuld. Aangezien dispensatie door de Bevelhebber der Landstrijdkrachten als ongewenst wordt beschouwd, is de enige integratiemogelijkheid bij dienstongeschiktheid integratie als burger bij Delensie. Uitwerking van dit personeelsbeleid ligt buiten het bestek van dit onderzoek.

Preventieve maatregelen ter vermindering van het disfunctioneren van de onderste extremiteiten kunnen gericht zijn op het voorkomen van blessures en overbelasting. aangezien deze vaak gelokaliseerd zijn in de onderste extremiteiten. De meeste trainingsletsels ontstaan tijdens de opleiding voornamelijk bij velddiensten en marsen, en in iets mindere mate door 'het vak lichamelijke oefening' en activiteiten in de vrije tijd. Het aantal blessures tijdens de trainingen van het Commando Opleidingen van de Koninklijke Landmacht (COKL) van 2 en 4 maanden is respectievelijk $34 \%$ en $44 \%$ van het aantal personen in opleiding. Dit blijkt uit een onderzoek bij 1186 dienstplichtig militairen van de lichtingsploeg 89-2, een groep die is opgekomen in maart $1989^{\prime 2}$. De belangrijkste oorzaken zijn ongevallen, overbelasting en vermoeidheid, persoonsgebonden factoren (zoals onvoorzichtig gedrag en onvoldoende conditie) en het militaire schoeisel. De blessures leiden vaak tot een bezoek aan de onderdeelsarts en tot opleidingsverzuim. In hoeverre dit weer leidt tot een ongeschiktheidsverklaring is niet bekend. Trainingsletsels ontstaan door de snelle opbouw en de relatief grote omvang van de trainingsbelasting in relatie tot de lichamelijke belastbaarheid van de dienstplichtigen ${ }^{24}$. Preventieve maatregelen tijdens de trainingsperiode zijn onder andere: het rustig inlopen van de militaire gevechtslaarzen, het uitvoeren van een 'warming-up' en 'cooling-down' bij het sporten en het voorlichten van instructeurs over training en blessurepreventie ${ }^{21}$.

\section{Reproduceerbaarheid}

Variatie in de beoordeling omtrent de medische geschiktheid is aangetoond. Men dient zich nu af te vragen of deze variatie acceptabel is. Gesteld kan worden dat zolang er geen consensus bestaat, variatie beter is dan het accepteren van een foute richtlijn ${ }^{25}$. Volgens de Nationale Raad voor de Volksgezondheid is variatie in beleid niet toelaatbaar als dit leidt tot een onrechtvaardige verdeling van de zorg ${ }^{26}$. Overeenkomstig is variatie niet toegestaan als er cen onrechtvaardige verdeling van de (dienstplicht) lasten ontstaat of als er een ongelijke kans is om op medische gronden te worden aangenomen of afgewezen.

De reproduceerbaarheid van de keuring blijkt onvoldoende te zijn, omdat de overeenkoms? tussen de artsen gering is. Met uitzondering van evidente gevallen, blijken medische criteria onvoldoende houvast te bieden bij de beoordeling van de geschiktheid voor de militaire dienst. 
Bij aandoeningen, waar objectieve meetmethoden aanwezig zijn en de wettelijke afkeurings-bepaling evident is, zal de uitslag reproduceerbaarder dan bij aandoeningen waar dit niet het geval is. De eerste groep aandoeningen valt onder het zogenaamde 'witte' gebied. Deze term is verwant aan teminologie betreffende het witte, grijze en zwarte ziekteverzuim ${ }^{14}$. In het witte gebied vallen objectiveerbare aandoeningen die bijvoorbeeld bij de constatering alleen al leiden tot een ongeschiktheidverklaring, zoals bij het syndroom van Down, diabetes mellitus en overgewicht. Over het grijze gebied wordt gesproken als aandoeningen niet alleen objectief meetbaar zijn. In het grijze gebied is zowel de beslissingsruimte van de arts als van de keurling groot, waardoor contextuele informatie en ziektegedrag belangrijk worden. Het ziektegedrag van de keurling kan bij dit grijze gebied naar gelang van zijn persoonlijke ambities en belangen variëren. Bij dienstplichtigen zullen deze persoonlijke belangen anders zijn dan bij beroepspersoneel. Daarnaast bepalen de instructies in het Aanwijzingenboek van keurend arts'n over de indeling van de ABOHZIS, de reikwijdte van het grijze gebied: de instructies kunnen zollanig zijn dat de arts een grote beslissingsvrijheid heeft ten aanzien van de ABOHZISgradering van de betreffende aandoening. Het zwarte gebied betreft het gebied waar artsen de geschiktheid van de keurlingen fout beoordelen, omdat de keurling bewust de arts misleidt. Bij dienstplichtkeuringen zullen door simulatic van de keurling meer onjuiste afkeuringen voorkomen dan onjuiste goedkeuringen. Bij beroepskeuringen zal dit waarschijnlijk andersom zijn. 


\subsection{De beschikbaarheid en bruikbaarheid van de keuringsgegevens voor weten- schappelijk onderzoek}

Hoewel de medische (dienstplicht)keuring een gezondheidsmeting is bij individuen, kunnen deze keuringsgegevens ook gebruikt worden voor wetenschappelijk onderzock ten aanzien van aspecten van de gezondheid van de Nederlandse mannelijke bevolking.

Vanaf 1978 worden keuringsgegevens bijgehouden in het medisch informatiesysteem KGO (Keuringen en Geneeskundige Onderzoeken) ${ }^{27}$.

Het onderzoek naar de prognostische factoren van het medisch disfunctioneren van dienstplichtigen bij de Koninklijke Landmacht (zie hoofdstuk 2.2) laat zien dat de data van het informatiesysteem gebruikt kunnen worden voor wetenschappelijk onderzoek met een direct belang voor het Ministerie van Defensie.

Volgens het rapport 'Volksgezondheid Toekomst Verkenning' zijn er onvoldoende gezondheidsgegevens op bevolkingsniveau in Nederland aanwezig ${ }^{25}$. Tegen deze achtergrond is de KGO-gegevensverzameling uniek te noemen. In principe gaat het om de hele Nederlandse mannelijke bevolking van vrijwel dezelfde leeftijd. Alleen degenen die pas later de Nederlandse nationaliteit hebben ontvangen en nog geen 35 jaar zijn, ondergaan de keuring op een later tijdstip. In 1993 was dit $9 \%$ van de totale groep gekeurden ${ }^{20}$.

Volgens Verzijden ${ }^{30}$ maken instellingen nauwelijks gebruik van bestaande registratiesystemen. Dit heeft verschillende redenen. In het kader van de bescherming van de privacy, mogen de gegevens alleen met grote zorgvuldigheid worden verspreid. Verder is het denkbaar dat onderzoekers niet op de hoogte zijn van de mogelijkheid om gegevens op te vragen. Onderzoekers kunnen gebruik maken van de, door het Centraal Bureau voor de Statistiek gepubliceerde, gegevens. Echter gedetailleerde informatie, die alleen via het Ministerie van Defensie kan worden aangevraagd, wordt dan niet verkregen. Soms kan de financiering van het onderzoek een bijkomend probleem zijn, als er geen bereidheid is te betalen voor het verkrijgen van informatie uit registraties, terwijl dit veel tijd zou besparen.

Nog meer inzicht in de relatie van de gezondheidstoestand met mogelijke determinanten kan men krijgen door dienstplichtgegevens te koppelen aan gegevens van andere daarvoor geschikte informatiesystemen, zodat men minimaal twee meetmomenten met elkaar kan vergelijken. Technische mogelijkheden om de data van het KGO-systeem te koppelen aan andere databestanden zijn aanwezig. Binnen het Ministerie van Defensie kunnen met behulp van identieke registratienummers de gegevens gekoppeld worden aan het systeem Verdere Automatisering Dienstplichtzaken (VADI). Het VADI-systeem wordt bij de Directie Diensiplicht gebruikt om niet-medische zaken af te handelen, zoals het inschrijven van de dienstplichtigen en eventuele uitstel- of vrijstellingsregelingen. De meest interessante variabelen van dit databestand zijn de onderwijs- en cursuscoderingen, waarmee de sociaal economische status kan worden nagegaan.

Voor het gebruik en het doorgeven van gegevens aan derden heeft het Ministerie van Delensie een eigen regeling opgesteld: Privacyreglement geneeskundige persoonsregistratie militair geneeskundig functiebeleid ". Zonder voorafgaande toestemming van de geregistreerde, kunnen gegevens worden verstrekt aan instanties voor statistiek en beleid indien de ver- 
strekking plaatsvindt in zodanige vorm dat die gegevens redelijkerwijs niet tot individuele personen herleidbaar zijn, en mits toestemming van de Commissie van Toezicht is verkregen. Dit geldt ook voor instanties voor wetenschappelijk onderzoek indien de gegevens zijn geanonimiseerd. Koppeling van gegevens uit de geneeskundige persoonsregistratie met gegevens uit een andere registratie buiten het militair geneeskundig functiegebied is niet toegestaan tenzij dit geschiedt ter uitvoering van een wettelijk voorschrift. Voor zover wij konden nagaan zijn dergelijke voorschriften niet aanwezig en is het derhalve niet mogelijk KGO te koppelen met externe bestanden, zoals die van het Rijksinstituut voor de Volksgezondheid en Milieu (RIVM) en TNO Preventie en Gezondheid.

In 1986 is een voorstel gedaan om het uitgebreide dataverzamelingssysteem, waarin de gegevens van 17-jarige Israëliërs die een militaire medische keuring hebben ondergaan, te gebruiken voor epidemiologisch onderzoek ${ }^{32}$. Aangegeven is hoe de gegevens te gebruiken zijn voor de verschillende soorten epidemiologisch onderzoek. Een soortgelijk voorstel is gedaan in Oostenrijk ". Tot nu toe heeft dit in Oostenrijk niet tot onderzoeksinitiatieven geleid. Daarentegen zijn dienstplichtgegevens in Israell, de Scandinavische landen, Zwitserland en Italië wel gebruikt voor epidemiologisch onderzoek, waarin de prevalentie en incidentie van ziekten, zoals diabetes mellitus centraal staat.

Ook in Nederland is in beperkte mate gebruik gemaakt van de keuringsgegevens. Geaggregeerde gegevens (afkomstig van KGO) zijn gepubliceerd door het Centraal Bureau voor de Statistiek (CBS) ${ }^{\text {m.s. }}$. De data hebben betrekking op de cerste dienstplichtkeuring: het aantal gekeurde dienstplichtigen, de keuringsuitslag, de afkeuringsreden, de geconstateerde alwijkingen, de ABOHZIS-classificatie van de geschikt bevonden keurlingen, het geboortejaar van de gekeurden. lengte en gewicht. Deze gegevens zijn ook per keurende instantie beschikbaar. Daarnaast zijn met dienstplichtgegevens regionale gezondheidsverschillen binnen de provincie Limburg bekeken ". Voorts zijn dienstplichtgegevens gebruikt bij de Toekomstverkenningen van de Nederlandse Volksgezondheid ten aanzien van diabetes mellitus en het lichaamsgewicht ${ }^{28}$. Diabetes mellitus blijkt vaker onderwerp van onderzoek te zijn. Niet alleen in Nederland ${ }^{\text {to.41 }}$ maar ook in andere landen is de omvang van deze aandoening nagegaan ${ }^{224}$.

De jaren zeventig en tachtig hebben in Nederland een aantal interessante longitudinale onderzoeken opgeleverd, die zijn verricht met data die door koppeling van dicnstplichtgrgevens aan externe bestanden zijn verkregen ${ }^{5-3}$. Zoals vermeld kan dit type onderzoek, vanwege de bescherming van de privacy, niet meer gedaan worden.

Bij gebruik van de dienstplichtgegevens voor wetenschappclijk onderzoek dient rekening te worden gehouden met de betrouwbarheid van de dataverzameling en de validiteit van de meetinstrumenten. Bij trendonderzoek dient men bovendien na te gaan of de methoden door de jaren heen zijn veranderd, doordat de medische cxpentise is verbeterd of veranderingen in de wijze van registreren hebben platsgevonden of andere richtlijnen zijn gaan gelden. Ook moet worden nagegaan of de bestudeerde aandoening e' $n$ evidente atkeuringsreden is, dan wel voor de bepaling van de geschikcheid van de dienstplichtige van zodanig belang is dat deze altijd tijdens de keuring wordt vastgelegd. Voorbeelden van aandoeningen die aan deze voorwaarden voldoen zijn: diabetes mellitus, het syndroom van Down, epilepsie, tuberculose, kleurenblindheid en myopie. Voorbeelden van determinanten zijn lengte en gowicht. 
Het is derhalve te hopen dat de tot nu toe verzamelde gegevens zorgvuldig worden bewaard en wel op een dusdanige wijze dat de gegevens toegankelijk blijven voor wetenschappelijk onderzoek naar de gezondheidstoestand. 


\subsection{Aanbevelingen ter verbetering van de kwaliteit van de militaire keuring en verder onderzoek}

\section{Aanbevelingen voor $\mathbf{k w a l i t e i t s v e r b e t e r i n g e n ~}$}

De resultaten van dit onderzoek leiden tot aanbevelingen ter verbetering van de militaire keuringen, zoals de dienstplichtkeuringen, aanstellingskeuringen en periodieke keuringen van beroepsmilitairen. Al deze keuringen werken volgens hetzelfde basisprincipe.

Gezien de overgang van dienstplichtig leger naar beroepsleger en de ontwikkeling dat de aanstellingskeuringen van alle krijgsmachtdelen centraal worden geregeld, zijn de aanbevelingen toegespitst op de keuring van beroepsmilitairen.

Volgens het wetsvoorstel op de medische keuringen kunnen keuringen alleen worden uitgevoerd indien voor de vervulling van de functie bijzondere eisen op het punt van de medische geschiktheid moeten worden gesteld. 'Onder medische geschiktheid voor de functie wordt begrepen de bescherming van de gezondheid en veiligheid van de keurling en van derden bij de uitvoering van de betreffende arbeid " $"$. De aanstellingskeuring voor militair personeel moet blijven bestaan, aangezien de militair risicovolle taken uitvoert. Zijn medische, geestelijke en fysieke conditie dient optimaal te zijn en mag de eigen veiligheid en die van derden niet in gevaar brengen ${ }^{30}$.

Om aan te sluiten op de ontwikkelingen in de burgermaatschappij is een belangrijke aanbeveling dat ook bij militaire keuringen functiegericht gekeurd wordt. Door het functiegericht keuren heeft het $\mathrm{ABOHZIS}$-classificatiesysteem geen waarde meer voor de krijgsmacht 'nieuwe stijl', niet alleen omdat het systeem onvoldoende gericht is op functie-eisen, maar ook omdat de reproceerbaarheid te gering is. De tijd is aangebroken om het ABOHZIS-classificatiesysteem af te schaffen.

In noodsituaties waar door een oorlogsdreiging het leger massaal moet optreden, kan de Dienstplichtwet weer in werking worden gesteld. De dienstplichtigen dienen dan snel te worden gemobiliseerd en ingedeeld. Alleen als onvoldoende tijd en capaciteit aanwezig zijn om alle geschikte dienstplichtigen functiegericht te herkeuren, kunnen de dienstplichtigen met behulp van het ABOHzIS-systeem worden ingedeeld. Slechts in deze situatie is het gerechtvaardigd het systeem te gebruiken.

Het ABOHZIS-systeem heeft een wettelijke kader, waardoor afschafling van het systeem een ingrijpende en langdurige procedure met zich meebrengt. In deze periode kan, ter vervanging van de ABOHzIS, een nieuw systeem worden ontwikkeld dat wel voldoet aan de eisen van functiegerichtheid en bovendien reproduceerbaarder is, zodat het nieuwe beroepsleger zo snel mogelijk functiegericht wordt gekeurd.

Bij de reorganisatie van het Ministerie van Defensie en de overgang van een dienstplichtig leger naar een beroepsleger zijn de ontwikkelingen zodanig dat door de DWS de aanstellingskeuringen van alle krijgsmachtdelen worden verricht. Jaarlijks zijn dat ongeveer 16.000 keuringen ${ }^{20}$. Naast het medisch onderzoek vindt ook een psychologisch onderzoek plaats. Dit omvat voor $80 \%$ het Basis Psychologisch Onderzoek en voor $20 \%$ het functiespecifieke deel. Ten behoeve van specifieke functiegroepen worden aparte testen afgenomen. Meer aandacht dan voorheen zal worden geschonken aan de geschiktheid ten aanzien van uitzendbaarheid 
Het Ministerie van Defensie is nog niet zover dat het volledig functiegericht keurt, in die zin dat voor elke functie specifieke functie-eisen aanwezig zijn, die in medische eisen zijn vertaald. Alleen voor sommige functiegroepen zijn specilieke eisen aanwezig. Een goed voorbeeld is het eisenpakket voor de F16-piloten van de KLU.

De ontwikkeling van het somagram-functiegram sluit goed bij aan het principe van functiegericht keuren. Het dient als communicatiemiddel tussen twee systemen, die een verschillend referentiekader hebben.

Vanuit de KL is sinds 1990 een vereenvoudigde versie ontwikkeld, die zich richt op de fysieke belasting en belastbaarheid van de militair.

Tot nu toe wordt de fysieke belasting/belastbaarheid van de militair gemeten aan de hand van de VFO-test (VFO= Vaststellen Fysieke Opleidbaarheid). Met deze test wordt gemeten of een militair aan het einde van de opleiding de gewenste lichamelijke conditie kan bereiken. Dit. betekent echter niet dat hij/zij de fysieke belasting tijdens de uitvoering van de functie aan kan. Derhalve zijn de 'vijf kritieke functie-aspecten' ontwikkeld (zie paragraaf 1.1.6). Behalve de algemene conditie worden de taken lopen met bepakking, herhaald tillen, graven en dragen onderscheiden.

De fysieke belastbaarheid van de persoon is uitgewerkt door de Sectie Trainingsgeneeskunde en Trainingsfysiologie. Verder is de Directie Militair Geneeskundig Beleid (via het Werkverband Militaire Keuringen) bezig de medische aspecten vast te stellen welke tijdens de keuring op grond van functie-eisen, dienen te worden beoordeeld en op welke wijze. Het voorstel is dat voor alle functies, te beginnen met BBT'ers, de functie-eisen worden uitgewerkt. Indien deze functie-eisen gereed zijn, kunnen ze in medische eisen worden overgezet. Ze worden afgestemd op de fysieke en medische belastbaarheid. Voor een succesvol systeem is een goede samenwerking tussen de betrokken 'zuilen' binnen de krijgsmacht (Directic Militair Geneeskundig Beleid, Sectie Trainingsgeneeskunde en Trainingsfysiologie en Centrale Dienst Personeel en Organisatie) noodzakelijk.

Een andere reden om functiegericht te keuren is dat deze wijze van keuren kan leiden tot een grotere reproduceerbaarheid dan het huidige militaire keuringssysteem. Functiegericht keuren zal de inter-dokterovereenstemming waarschijnlijk verhogen. De beslissingsvrijheid van de arts wordt verminderd, omdat de interpretatie van de medische belastbaarheid ten opzichte van de functie-eisen en daaruit voortvloeiende medische eisen duidelijker wordt. Als men overgaat tot functiegericht keuren, kan overwogen worden om artsen zich te laten specialiseren in het keuren voor specifieke functies. Deze werkwijze kan eveneens een bijdrage leveren aan de verhoging van de reproduceerbaarheid.

Door middel van een doorstroombeleid kunnen astsen zich verdiepen in verschillende functiecategorieën, waardoor eentonigheid wordt vermeden. Een bijkomend voordeel is dat bij ziekte of verlof artsen onderling vervangbaar zijn.

Een andere wijze om de reproduceerbaarheid te verhogen is meer aandach te besteden aan intercollegiaal overleg en toetsing. Datzelfde geldt voor introductiecursussen voor beginnend arisen. 
Het doel van deze aanbevelingen is uiteraard niet de reproduceerbaarheid als zodanig, maar het detecteren van potentiële medische disfunctioneerders. Reproduceerbaarheid is immers een essentiële voorwaarde voor een valide keuring.

\section{Aanbevelingen voor verder onderzoek}

Verder onderzoek dient - door de opschorting van de opkomstplicht - gericht te zijn op de kwaliteit van de keuringen van beroepsmilitairen.

Allereerst kunnen kwaliteitsaspecten die al bij de dienstplichtkeuringen zijn nagegaan, ook bij keuringen voor beroepsmilitairen worden onderzocht. Daarbij dient rekening te worden gehouden met de specifieke kenmerken en problemen van beroepsmilitairen.

Om de validiteit van de aanstellingskeuringen van vrijwillig dienende militairen te bepalen, kan men onderzoek verrichten naar het medisch disfunctioneren van deze populatie. De uitkomsten daarvan komen ten goede aan de ontwikkeling van meetinstrumenten met voldoende voorspellende waarde, zoals in het Protocol Aanstellingskeuringen voor dit soort functies wordt aanbevolen".

Uit het onderzoek naar het medisch disfunctioneren bij dienstplichtigen is naar voren gekomen welke de consequenties zijn van een verzwaring van de selectie-eisen. Binnen de krijgsmacht 'nieuwe stijl' kan de situatie zich voordoen dat de functie-eisen en de daaruit voortvloeiende medische eisen voor de beroepsmilitairen veranderen. Met name wijzigingen in vraag en aanbod kunnen hiervan de oorzaak zijn. Zeker als men in de toekomst overweegi de functie-eisen voor de beroepsmilitairen te verzwaren of te verlichten, is het zinvol de gevolgen daarvan aan de hand van prospectief onderzoek na te gaan.

Een algemeen probleem bij het bepalen van de validiteit is het ontbreken van de gegevens over de afgekeurden. Indien informatie verzameld kan worden over de afgekeurden, kunnen aspecten die tot nu toe niet bekend zijn worden onderzocht. Met een bepaling van het percentage ten onrechte afgekeurden wordt het dan mogelijk, naast de negatieve voorspellende waarde, ook de sensitiviteit, specificiteit en de positieve voorspellende waarde na te gaan. Zoals reeds bij de 'kritische kanttekeningen' is aangegeven, zijn op dit moment geen valide meetinstrumenten beschikbaar om het percentage ten onrechte ongeschikt verklaarden te achterhalen.

Wat betreft de reproduceerbaarheid is aan te bevelen de mate van overeenkomst tussen de artsen met behulp van simulatiekeurlingen na te gaan, in plaats van met schriftelijke dossiers. Ideaal is als alle artsen dezelfde keurlingen beoordelen op geschiktheid voor de militaire dienst, zonder te weten dat zij op dat moment aan het onderzoek meewerken. Voor de praktijk betekent dit dat de keurling dusdanig getraind moet worden, dat hij - met name tijdens het lichamelijk onderzoek - correct en consequent simuleert. De artsen mogen de simulanten niet herkennen. De simulatickeurlingen moeten ongemerkt (dus met 'officiële' papieren) het keuringsiraject doorlopen. Onderzoek van Rethans "2 heeft laten zien dat praktische problemen in deze oplosbaar zijn. Bij zijn onderzoek hebben getrainde personen huisartsen bezocht 
om na te gaan of zij bepaalde protocollen in de praktijk ook toepassen. De personen waren dusdanig getraind dat zij bij elke arts hetzelfde gedrag vertoonden. Een onderzoek met simulatiekeurlingen is een uitdaging om de mate van overeenkomst tussen de keurend artsen nog beter te achterhalen. Als men serieus overweegt om de keuring reproduceerder te maken wordt aanbevolen de effectiviteit van deze methode te evalueren.

\section{Samenvattend}

Voor het eerst zijn de keuringen binnen Nederlands krijgsmacht bij de discussie over aanstellingskeuringen betrokken. Deze keuringen behoren tot die categorie, waarbij het uitvoeren van de functie dusdanige gezondheids- en veiligheidsrisico's met zich mee kan brengen dat een medische keuring noodzakelijk is.

Het blijkt mogelijk te zijn om het medisch disfunctioneren aan de hand van prognostische factoren te voorspellen. De voorspellende waarde van de keuring was al $91,9 \%$ en kan door het toepassen van risicoprofielen ten aanzien van het disfunctioneren wegens aandoeningen van de onderste extremiteiten en de rug enigszins worden verhoogd. Duidelijk is gemaakt dat alvorens dit extra selectiemiddel te hanteren overwogen dient te worden hoe de door de betrokkene ervaren schade door een onterechte uitsluiting zich verhoudt ten opzichte van de gezondheidsschade die door de extra selectie kan worden voorkomen.

Hoewel strikte richtlijnen ten aanzien van het keuren aanwezig zijn, is toch gebleken dat de reproduceerbaarheid aanzienlijk verbeterd kan worden. De besluitvorming van de arts blijkt niet alleen afhankelijk te zijn van de aard en de ernst van de aandoeningen, maar ook contextuele gegevens kunnen een rol spelen, waaraan elke arts weer een ander gewicht toekent.

Verbetering van de kwaliteit van de keuring kan verkregen worden door:

- onderzoek te verrichten naar risicuproficlen voor medisch disfunctioneren bij het beroepsleger;

- functiegericht te keuren;

- onderzoek te doen naar het besluitvormingsproces van de keurend artsen met behulp van 'simulatiekeurlingen';

- trainingen te geven aan artsen en intercollegiale toctsing te bevorderen.

Zelfs bij de invoering van deze en andere verbeteringen, blijft keuren mensenwerk. 


\section{Literatuur}

1 Lamberts H. Een psychosociaal, anthropometrisch en arbeidsfysiologisch profiel van gewone en van geestelijk niet-stabiele dienstplichtigen [proefschrift]. Rijksuniversiteit Leiden, 1969.

Albertsma T. Aantallen en redenen van afkeuring van dienstplichtigen bij de Koninklijke Luchtmacht. Nederl Milit Geneesk T 1986;39:19-22.

Levy A, Blech A, Chen E. Israelli adolescents and military service: encounters. Adolescence 1987;22:945-51.

4 Turnhout S, Vullinghs HFM, Weterings M. Exit-onderzoek: schoolbataljon I div ' 7 december'. Den Haag: Ministerie van Defensie (in press).

Flach A, Weterings M. Afmaken of afhaken. Voorspellers in psychologische selectie voor opleidingsverloop bij BBTers van het Schoolbataljon 11 Luchtmobiele Brigade. Den Haag: Ministerie van Defensie, 1996.

Ankoné A. Wettelijk arbeidsgeschikt en sociaal arbeidsongeschikt. Medisch contact 1995;50:663-6. Nijhuis FJN. De paradoxale gezondheidseffecten van arbeid [Oratie]. Rijksuniversiteit Limburg. 1995

$8 \quad$ Putten $\mathrm{P}$ van der. Een onderzoek naar de oorzaken van arbeidsongeschiktheid bij overheidspersoneel. T Soc Geneesk 1981:59:695-9.

Koninklijke Nederlandse Maatschappij tor bevordering der Geneeskunst. Protocol Aanstellingskeuringen: een protocol ten behoeve van werkgevers en artsen betrokken bij aanstellingskeuringen. Utrecht, 1995.

10 Jonas TV, Gerrity MS, Earp J. Written case simulations: do they predict physicians' behavior? J Clin Epidemiol 1990:43:805-15.

11 Lourijsen ECMP, Dam J. Het keurings- en besluitvormimgsproces bij aanstellingskeuringen: een voorstudie onder tien artsen. Leiden: NIPG/TNO. nr 90.076, 1990

Kort de WLAM, Post Uiterweert HW. Project aanstellingskeuringen dossieronderzoek bij de RBB. Deel II: panelonderzoek. Den Haag: Ministerie van Sociale zaken en werkgelegenheid, nr 553-2, 1991.

13 Kort WLAM de. Personnel selection through pre-employment medicals [proefschrift]. Universiteit van Amsterdam, 1993.

Philipsen H. Afwezigheid wegens ziekte. Groningen: Wolters Noordhoff, 1969.

15 Duindam S. Militaire dienstplicht: een economische benadering van de personeelscomponent in de krijgsmacht [proefschrift]. Rijksuniversiteit Limburg. 1995.

16 Eck JCM van. Biografische, temperaments- en persoonlijkheidskenmerken. Een ondersoek: naar verschillen russen functionerende en disfunctionerende diensiplichtig militairen bij de Koninklijke Landmacht. Den Haag: Ministerie van Defensie, 1992.

17 Slagmaat van GP. Weterings M. Screening van dienstplichtig personeel voor uitzending naar voormalig Joegoslavië. Effectiviteitsbeoordeling van dienstplichtigen in uitzendgebied. Den Haag: Ministeric van Defensie. 1996.

18 Dijk FJH van, Weide $W$ van der. Zet ' $m$ op, scoor een job. Tijdschr Soc Gezondheidsz 1995;73:503-4.

19 Dijk FJH van. Weide W van der. Repliek. Tijdschr Soc Gezondheidsz 1996:74:79. Commentaar op: Tijdschr Soc Gezondheidsz 1996;74:78-9.

20 Defensie Werving en Selectie. Het Geneeskundig onderzoek bij defensie organisatie voor werving en selectic. Den Haag: Ministerie van Defensie, 1996.

21 Swaan A de. De mens is de mens een zorg. Amsterdam: Meulenhoff, 1982. 
Pusi Uiterweert HW, Aanstellingskeuringen. In: Veld RA in 't, Verbeek JHAM, Boskamp P. Het groot arbowerk. Samsom Bedrijfsinformatie, 1996.

I)ijk MJ van. Blessures bij diensiplichtige militairen en identificatie van risico-profielen, rappornr 9105/TF, Utrecht: Ministerie van Delensie, BGZ/IGDKL, Sectie Trainingsgeneeskunde en Trainingsfysiologic', 1991 .

Dijk MJ van. Incidentie van trainingsletsels bij dienstplichtige militairen. rappornr 8606-1008, Utrecht: Ministerie van Defensie, IGDKL, Sectie Trainingsgeneeskunde en Trainingslysiologie, 1986. Stiggelhout AM, Timmermans DRM. Variatie in beleid en kwaliteit van medische besluitvorming: beperking van een bijeenkomst van het Landelijk Forum Medische Besliskunde. Ned Tijdschr Gencesk 1995:139:1144-8.

Nationale Raad voor de Volksgezondheid. Kanttekeningen bij rapport Commissie Hoefnagels. Zoeterneer: Nationale Raad voor de Volksgezondheid, 1990. Bommurijn H. Milgins: een grove schets. Nederl Milit Geneesk T 1991;44:145-76. Rijksinstituut voor Volksgezondheid en Milieu (RIVM). Volksgezondheid Toekomst Verkenning: de ge/ondheidstoestand van de Nederlandse bevolking 1950-2010. Den Haag: SDU uitgeverij, I993. Ministeric van Defensie, Directie Dienstplichtzaken. Jaaroverzicht dienstplichtgegevens 1993. Kerkrade: Ministerie van Defensie, 1994. Verzijden S, e.a. Onderzoek en medische registraties: een bruikbaarheidsbeoordeling op sociaaleconomische status en gezondheidsverschillen. Utrecht: Informatiecentrum voor de Gezondheidszorg. 1991.

Ministcric van Defensie. Privacyreglement geneeskundige persoonsregistratie militair geneeskundig functicheleid. MP 11-85. Den Haag, 1995.

Kark JP, Kedam R, Revach M. Medical cxamination of Israel 17-years old before military service as a national resource for health information. Isr $J$ Med Sci 1986;22:318-25.

Jenny E, Lingg G. Nussbaumer W. Die bedeutung der stellungsuntersuchung in der praventivmedizin und als grundlage epidemiologischer studien. Osterr Artzezig 1985;40:15/16:25-33. Centraal bureau voor de statistiek, Ministerie van Volksgezondheid en Milieuhygiene. Compendium Gezondheidsstatistiek Nederland, - (1) 1974 - (2) 1979 - (3) 1986. Den Haag: Staatuitgeverij, 1974-1986.

Centraal Bureau voor de. Statistiek, Ministerie van Volksgezondheid en Milieuhygicne. Vademecum gezondheidsstatistiek Nederland. - (1) 1977 - (2) 1978 - (3) 1981 - (4) 1982 - (5) 1983 - (6) 1984 (7) 1989 - (8) 1991 - (9) 1992 - (10) 1993 - (11) 1994 - (12) 1995 - Den Haag: Staatuitgeverij. $1977-1995$.

Ceniraal Bureau voor de Statistiek. De statistisch jaarboeken $1990 \mathrm{t} / \mathrm{m}$ 1995. Den Haag: SDU uitgeverij/CBS-publicaties, 1990-1995.

37 Cintraal Bureau voor de Statistiek, Hoofdafdeling Gezondheidsstatistieken. De maandberichten Gezondheidsstativtiek 1982 l/m 1991, Den Haag: SDU Uitgeverij/CBS-publicaties, 1982-1992. Central Bureau voor de Statistiek. Hoofdafdeling Gezondheidsstatistieken. Dienstplichtkeuringen: Resultaten van de keuring van dienstplichtigen 1990. Maandbericht Gezondheidssiatistiek mei 1992. Den Haag: SDU Uitgeverij/CBS-publicaties, 1992.

39 Bisscheroux P. e.a. Gezondheidsvademecum Limburg: een epidemiologisch overzicht: regionale cijfers. Maastricht: Rijksuniversiteit Limburg, Medisch en Maatschappelijk Informatiecentrum (MEMIC), 1986.

\section{Keuren is Mensenwerk}


Drykoningen CEM, Mulder ALM, Vaandrager GJ, LaPorte RE en Bruining GJ. The incidence of male childhood Type I (insulin-dependent) diabetes mellitus is rising rapidly in The Netherlands. Diabetologia 1992:35:139-42.

4.1 Ruwaard D. Hirasing RA, e.a. Increasing incidence of type I Diabetes in The Netherlands, Diabetes Care 1994:17:599-601.

42 Songini $M$, Loche $M$, e.a. Increasing prevalence of juvenile onset Type I (insulin-dependent) diabetes mellitus in Sardinia: the military service approach. Diabetologia 1993;36: 547-52.

43 Green A, Andersen PK, Svendsen AJ en Mortensen K. Increasing incidence of early onset Type 1 (insulin-dependent) diabetes mellitus: a study of Danish male birth cohorts. Diabetolgia 1992;35:178-82.

44 Teuscher AU, Diem P, Thomas W, Janett J, Teuscher A. Häufigkeit des insulin-abhängigen diabetes mellitus in der Schweiz (1972-1993) bei 19jährigen männern. Schweiz Med Wochenschr 1995; 125:1041 -5.

45 Siein Z, Susser M, Sturmans F. Famine and mortality. T Soc Geneeskunde 1975:53:134-41.

46 Hoffmans MDAF, Kromhout D, Lezenne Coulander $C$ de. The impact of body mass index of 78,612 18-years old Dutch men on 32-year mortality from all causes. J Clin Epidemiol 1988;41:749-56.

47 Hoffmans MADF, Kromhout D, Lezenne Coulander $C$ de. Body mass index at the age of 18 and its effect on 32-year-mortality from coronary heart disease and cancer. A nested case-control study among the entire 1932 dutch male birth cohort. J Clin Epidemiol 1989:42:513-20.

48 Doombos $G$, Kromhout D. Educational level and mortality in a 32-year follow-up study of 18-yearold men in the Netherlands. International Journal of Epidemiology 1990; 19:374-9.

Voorstel van de wet van het lid Kohnstamm (en later Van Boxtel) houdende regels tot versterking van de rechtspositie van hen die een medische keuring ondergaan (Wet op de Medische keuringen) Tweede Kamer vergaderjaar 1993-1994, 1994-1995 en 1995-1996, nr 23 258, 1-25.

50 Samuels FAM. De rechtspositie en de rol van de geneeskundige dienst. Nederl Milit Geneesk T 1995:47:17-21.

51 Ministerie van Defensie, Defensie Werving en Selectie. Het psychologisch onderzoek bij defensie organisatie voor werving en selectie. Den Haag: Ministerie van Defensie, 1996.

Rethans JJ. Does competence predict performance? [proefschrift]. Rijksuniversiteit Limburg, 1990. 


\section{SAMENVATTING}

Doelstelling van dit proefschrift is het zoeken naar verbeteringen van de kwaliteit van de medische keuringen binnen de Nederlandse krijgsmacht. Bijzondere aandacht is geschonken aan dienstplichtkeuringen en keuringen voor vrijwillig dienende militairen van de Koninklijke Landmacht.

Ofschoon er door de opschorting van de opkomstplicht per 1 januari 1997 geen dienstplichtkeuringen meer worden verricht, is dit onderzoek toch relevant. Dienstplichtkeuringen kunnen in de toekomst weer actueel worden als de Dienstplichtwet door calamiteiten of oorlogsdreiging in werking treedt. Daarnaast vormen de eisen en procedures van dienstplichtkeuringen de basis van alle militairen keuringen (o.a. aanstellingskeuringen en periodiek geneeskundige onderzoeken binnen de krijgsmacht). De resultaten zijn daardoor van belang voor al deze medische keuringen binnen de krijgsmacht. Suggesties ter verbetering van het keuringsapparaat zijn derhalve krijgsmachtbreed.

De dienstplichtkeuring is te beschouwen als een bijzonderc vorm van de aanstellingskeuring. In de burgermaatschappij staan aanstellingskeuringen in de volle belangstclling. Het gaat daarbij vooral over de eflectiviteit van de aanstellingskeuring als instrument voor selectic en risicowering. Aanstellingskeuringen zijn alleen wenselijk of noodzakelijk voor functies waar de persoon in kwestic of derden belangrijke gezondheids- en/of veiligheidsrisico's loopt/lopen. En dit geldt ook voor militaire functies.

In hoofdstuk 1 wordt de betekenis van (aanstellings)keuringen en in het bijzonder van keuringen binnen de krijgsmacht heschreven (paragraaf 1.1).

Uniek aan militaire keuringen is dat, in tegenstelling tot vele aanstellingskeuringen in de burgermaatschappij, gedetailleerde richtlijnen gebruikt worden. De keuringsuitslag wordt beoordeeld aun de hand van het militair keuringsreglement (MKR) en het Aanwijzingenbock voor artsen die belast zijn met militaire keuringen. De arts dient niet alleen de keuringsuitslag vast te stellen; ook dienen aanwezige ziekten en gebreken volgens de codering van de International Classification of Disease (ICD) te worden vastgelegd. Bij een geschiktverklaring kent de arts een ABOHZIS-classificatie aan de persoon toe. De ABOHZIS-classificatie dient als hulpmiddel bij het indelen naar lunctie van de goedgekeurden. Elke letter van de ABOHZIS staat voor een bepaalde rubriek: $A=$ Algemeen fysieke toestand; $B=$ Bovenste ledematen; $O=$ Onderste ledematen en rug; $\mathrm{H}=$ Horen; $\mathrm{Z}=\mathrm{Zien} ; \mathrm{I}=$ Intelligentie en $\mathrm{S}=$ (Psychische) Stabiliteit. Bij het constateren van ongeschiktheid dient de arts de reden van afkeuring aan te geven in een code conform een lijst van het MKR en de rubriek van de ABOHZIS-classificalie waarop de afkeuring betrekking heeft.

De actuele mogelijkheden om de kwaliteit van de militaire keuringen te onderzoeken worden vervolgens in paragraaf 1.2 besproken. De belangrijkste aspecten om de kwaliteit van de keuring te meten zijn reproduceerbaarheid en validiteit.

De reproduceerbaarheid geeft aan in hoeverre de keuring dezelfde uitslag oplevert, indien deze op meerdere momenten plaatvindt of door andere artsen wordt verricht.

Bij de militaire keuring kan deze worden bepaald door na te gaan in welke mate de keurend artsen overeenstemmen in de beoordeling van de medische geschiktheid voor militaire dienst. 
Reproduceerbaarheid is een voorwaarde van een valide keuring. De validiteit geeft aan in hoeverre met de keuring de geschiktheid van de gekeurden juist beoordeeld wordt. Door het ontbreken van de gegevens over de afgekeurden, zijn de mogelijkheden om de validiteit van de keuring te bepalen beperkt. Alleen de mate waarin dienstplichtigen in dienst om medische redenen worden afgekeurd kan worden nagegaan. Dit geeft een indicatie van de voorspellende waarde van de keuring. Prognostische factoren van dit medisch disfunctioneren kunnen worden nagegaan, zodat aan de hand van risicoprofielen het medisch disfunctioneren beter kan worden voorspeld.

Het onderzoek is toegespitst op de voorspellende waarde en de reproduceerbaarheid van de keuring. Dit heeft geleid tot de volgende vraagstellingen:

- In hoeverre is het mogelijk het medisch disfunctioneren in militaire dienst te voorspellen?

- In welke mate zijn militaire keuringen reproduceerbaar?

In hoofdstuk 2 wordt de eerste vraagstelling beantwoord met behulp van dienstplichtgegevens. In paragraaf $\mathbf{2 . 1}$ wordt het keuringstraject van de dienstplicht beschreven. Een groep van 118.716 dienstplichtigen wordt van het begin (vanaf 1987) tot het einde van dit traject gevolgd. Ondanks de uitgebreide medische selectie disfunctioneert zes procent van deze dienstplichtigen in diensttijd bij de Koninklijke Landmacht om medische redenen.

Nader onderzoek naar de medische disfunctioneerders is beschreven in paragraaf 2.2. De resultaten van het retrospectieve cohortonderzoek bij 8714 dienstplichtigen die in 1989 de eerste dienstplichtkeuring hebben ondergaan en in 1990 bij de Koninklijke Landmacht zijn opgekomen, worden weergegeven. De meeste disfunctioneerders blijken ongeschikt te zijn verklaard wegens aandoeningen van de onderste extremiteiten inclusief de rug of onvoldoende psychische stabiliteit.

Met behulp van logistische regressieanalyse is gezocht naar risicoprofielen die deze twee soorten van disfunctioneren kunnen voorspellen voordat de dienstplichtigen in dienst komen. Prognostische factoren van het disfunctioneren wegens aandoeningen van de onderste extremiteiten en de rug zijn: het constateren van een functiebeperking tijdens de eerste keuring op grond van aandoeningen van de onderste extremiteiten en de rug, die in eerste instantie geen alkeuring leck te rechtvaardigen of het ondergaan van een herkeuring omdat men bij de eerste keuring tijdelijk ongeschikt is verklaard en/of het ondergaan van een extra keuring naar aanleiding van de gegevens ingevuld op het anamneseformulier vlak vóor opkomst. Prognostische factoren van het disfunctioneren vanwege onvoldoende psychische stabiliteit zijn: het hebben van een psychische stoomis bij de eerste keuring die niet lot een afkeuring leek te hoeven leiden, een bipatride nationaliteit en terechtkomen in die lichtingsploegen, waar het aanbod van dienstplichtigen kleiner is dan de overige lichtingsploegen. Met behulp van de, op de prognostische factoren gebaseerde, risicoprofielen kan de kans om te disfunctioneren wegens aandoeningen van de onderste extremiteiten inclusief de rug of onvoldoende psychische stabiliteit vóór opkomst worden berekend. Als bij de keuring dit extra selectiemiddel gehanteerd zou worden en dienstplichtigen met een verhoogd risico niet in dienst komen, kan het aantal medische disfunctioneerders in beperkte mate worden verminderd. De uitkomsten van dit onderzoek hebben geleid tot een discussie in het Tijdschrift Sociale Gezondheidszorg over de voor-en nadelen van deze selectiemethode. In bijlage 1, 2 en 3 is deze discussie letierlijk weergegeven. 
Hoofdstuk 3 geeft de resultaten van onderzoeken die verricht zijn om de reproduceerbaarheid van militaire keuringen te achterhalen.

Allereerst worden in paragraaf $\mathbf{3 . 1}$ de gegevens van de dienstplichtkeuringen van 1993 geanalyseerd. Iets meer dan de helft van de afkeuringen blijkt betrekking te hebben op aandoeningen die vallen onder de algemene fysieke toestand of aandoeningen van de onderste extremiteiten inclusief de rug. Er blijkt aanzienlijke variatie te zijn wat betreft de beoordeling van de medische geschiktheid van dienstplichtigen. Dit geldt zowel tussen de indelingsraden als tussen de artsen. De grootste variatie is aanwezig bij de afkeuringen op grond van aandoeningen van de onderste extremiteiten en de rug. De variatie is deels te verklaren door procedureverschillen tussen de indelingsraden met betrekking tot het alkeuren wegens onvoldoende gehoor- en gezichtsvermogen. De overige inter-raadvariatie is het gevolg van verschillen tussen de individuele artsen.

In paragraaf 3.2 wordt een experiment beschreven naar de mate van overeenstemming ussen artsen omtrent de medische geschiktheid van dienstplichtigen voor militaire dienst. Een 36-tal artsen hebben bij 14 geselecteerde 'moeilijk beoordeelbare' casussen (met betrekking tot aandoeningen van de onderste extremititeiten en de rug) de geschiktheid van dienstplichtigen beoordeeld. De mate van overeenstemming tussen artsen is bepaald met behulp van Cohen's kappa. De kappawaarde kan variëren tussen 0 en 1 , waarbij een waarde van 0 tot 0.40 impliceert dat er een slechte overeenstemming is. Zowel de overeenstemming bij de keuringsuitslag als bij de beoordeling van de beperkingen ten aanzien van onderste extremiteiten en de rug is slecht: de kappa bedraagt respectievelijk 0.20 en 0.17 . De overeenstemming tussen de artsen binnen één indelingsraad is ook laag: tussen de indelingsraden schommelt de kappa tussen 0.19 en 0.40 betreffende de keuringsuitslag en tussen 0.13 en 0.35 betreffende beperkingen door aandoeningen van de onderste extremiteiten en de rug. Intercollegiaal overleg en de sturing door het hoofd van de artsen op de indelingsraad hebben niet een zodanig overwicht dat de artsen van eenzelfde raad hetzelfde beleid voeren. Tevens lijkı contextuele informatie de overeenstemming tussen artsen te verlagen: bij casussen met deze informatie bedraagt de kappa ten aanzien van de keuringsuitslag 0.07 , terwijl die bij casussen zonder contextuele informatie 0.35 is. Wat betrefi de beperkingen door aandoeningen van de onderste extremiteiten en de rug is dit 0.07 ten opzichte van 0.21 .

Ter verbetering van de overeenstemming zou men kunnen overwegen functiegericht te keuren. Een aanvullende mogelijkheid is dat artsen zich specialiseren in het beoordelen van specifieke functies of functiegroepen. Daarnaast zou meer aandacht besteed kunnen worden aan intercollegiaal overleg. Trainingen zijn zinvol voor keurend artsen. Dat geldt vooral voor degenen die de artsen inwerken.

In paragraaf 3.3 wordt een aanvullend onderzoek beschreven naar de overeenkomst tussen artsen die periodiek geneeskundig onderzoek (PGO's) verrichten bij beroepspersoneel van de Koninklijke Landmacht. Bij dit onderzoek zijn 24 aselect gekozen casussen voorgelegd aan 2 artsen. De overeenkomst tussen beoordelingen van de oorspronkelijke arts en de beoordelingen van de twee andere artsen is vastgesteld aan de hand van Cohen's kappa.

Bij deze keuringen geven de artsen niet alleen de keuringsuitslag en de ABOHZIS-classificatie, maar ook de medische beperkingen aan. De overeenkomst ten aanzien van de keuringsuitslag is onder te verdelen naar de beoordeling van de A-rubriek (de algemene fysieke toestand), de 
B-rubriek (aandoeningen van de bovenste extremiteiten) en de O-rubriek (aandoeningen van de onderste extremiteiten en de rug). De kappa bedraagt bij de beoordeling van de A-, B- en O-rubriek respectievelijk $0.16,0.52$ en 0.44 . Bij het wel of niet toekennen van een medische beperking is de kappa achtereenvolgens voor de A-, B- en O-rubriek 0.67, 0.74 en 0.65 .

Ook in dit onderzoek blijken de keuringsuitslagen op grond van de ABOHZIS-classificatie tussen individueel keurend artsen onvoldoende reproduceerbaar. De keuringsuitslag is derhalve niet alleen afhankelijk van de status praesens van de militair, maar ook van de keurend arts. Hel gebruik van de ABOHZIS-classificatie levert geen meerwaarde op bij het periodieke onderzoek naar de dienstgeschiktheid van de individuele militair.

In de beschouwing (hoofdstuk 4) is nagegaan in hocverre de vraggstellingen beantwoord zijn. Onderzoek heeft uitgew'en dat het medisch disfunctioncren op grond van de $\mathrm{O}$ - en $\mathrm{S}$ rubriek deels kan worden voorspeld aan de hand van risicoproticlen. Het aantal medische disfunctioneerders zal door dec extra sclectic kunnen verminderen. Echter een beperkt deel van de medische disfunctioneerders is onder danige impact dat de voorspellende waarde (van 91,9\% naar 92,3\%) aanzienlijk verhoogd wordt.

De overeenkomst tussen de artsen bij de beoordeling van schriftelijke dossiers is slecht. Dit geldt ten aanzien van de beoordeling van de keuringsuitslag zowel bij dienstplichtkeuringen als bij PGO's van vrijwillig dienende militairen van de Koninklijke Landmacht.

Voldoende reproduceerbaarheid van de keuringsuitslag van de militaire keuring kon niet worden vastgesteld, ondanks de richtlijnen die in de MKR en het Aanwijzingenboek zijn weergegeven om de keuring zo uniform mogelijk te laten verlopen. De arts beschikt, bij de beoordeling van de geschiktheid voor de militaire dienst, over een bepaalde mate van beslissingsruimte. Daardoor blijft keuren mensenwerk.

Naar aanleiding van de resultaten van het onderzoek zijn suggesties gedaan ter verbetering van de militaire keuringen, zoals de dienstplichtkeuringen, aanstellingskeuringen en periodieke keuringen voor beroepsmilitairen, die allen volgens hetzelfde basisprincipe werken. De belangrijkste aanbeveling is dat ook bij militaire keuringen functiegericht dient te worden gekeurd. Bij deze optie zou men ook kunnen overwegen om artsen zich te laten specialiseren in de beoordeling van specifieke functiegroepen, zoals chauffeurs of infanteristen.

Door het functiegericht keuren heeft het ABOHZIS-classificatiesysteem, mede door de te geringe reproduceerbaarheid, geen waarde meer voor de krijgsmacht 'nieuwe stijl'.

Binnen het principe van het functiegericht keuren past de ontwikkeling van het functiegramsomagram goed, omdat voor elke persoon de belasting van de functie word afgezet tegen de belastbaarheid van de persoon in kwestie.

Om in te spelen op de vernieuwingen binnen de krijgsmacht dient verder onderzoek te worden verricht naar de keuringen van het 'nieuwe' beroepspersoneel. Allereerst kan de mate van medisch disfunctioneren worden nagegaan. Zeker als het keuringssysteem verandert of de functie-eisen verzwaard of verlicht worden is het aan te bevelen het medisch disfunctioneren systematisch te evalueren. Deze evaluatie vormt een uitstekende graadmeter voor de voorspellende waarde van de keuring. Daarnaast kan worden onderzocht of het systeem van functiegericht keuren ten goede komt aan de reproduceerbarheid. 
In llavolging van eerder onderzoek kan het effect hiervan beter met simulatiekeurlingen gedaan worden dan met schriftelijke dossiers.

Tijdens het onderzoek is steeds weer opgevallen dat over de gehele Nederlandse mannelijke bevolking over een lange periode keuringsgegevens aanwezig zijn. De vraag is gerezen of deze gegevens ook voor een ander doel gebruikt kunnen worden dan waarvoor zij primair zijn bedoeld, namelijk als basis voor onderzoek naar de gezondheidstoestand van de 18 -jarige Nederlandse mannen. Gebleken is dat in het verleden hieromtrent onderzoek is verricht, mede door de mogelijkheid om de gegevens te koppelen aan externe bestanden. Ofschoon nu geen dienstplichtkeuringen meer worden verricht en de privacyregelingen koppeling met ('xterne bestanden niet toelaat, is het altijd mogelijk om retrospectief onderzoek te doen naar trends van belangrijke aandoeningen. Het zou betreurenswaardig zijn als deze waardevolle bron van informatie, door het verdwijnen van de dienstplichtigen, niet gebruikt wordt. 


\section{SUMMARY}

The purpose of this thesis is to determine the quality of the medical examination within the Dutch armed forces. Special attention is given to the examination of conscript and voluntary personnel of the Royal Netherlands Army (RNLA).

Despite the fact that conscription is being suspended in the Netherlands from I January 1997, this investigation is still relevant. The examination of conscripts could be reintroduced in times of a national calamity, or threat of war. Furthermore, the requirements and procedures of conscript exarnination form the basis of all military medical examinations.

Therefore, the results of the investigation and suggestions for improvement of the medical examination apparatus are important for all medical examinations within the armed forces. Conscripts' medical examination can be considered as a special form of pre-employment medical. In the Netherlands the issue of pre-employment medicals enjoys wide public interest. This discussion addresses the effectiveness of the pre-employment medical as an instrument for selection and avoiding risks. Pre-employment medicals are only recommended or necessary for jobs in which, as is the case in military functions, the health or safety risks are large.

Chapter 1 describes the meaning of the term (entrance) medical examination with particular reference to the military context (paragraph 1.1 ).

In comparison with civilian medical examinations, military medical examinations are unique in that they are conducted on the basis of detailed written guidelines.

Examination results are judged according to the Regulations for Military Medical Exarninations (abbreviated to MKR in Dutch) and are described in terms of the Book of Medical Indications available for physicians charged with this task.

Doctors not only determine a person's fitness; illnesses and disorders are recorded according to the International Classification of Diseases (ICD codes).

For the purposes of a declaration of fitness physicians classify persons undergoing a medical examination according to the ABOHZIS classification system. The ABOHZIS classification serves as an aid for assigning miliary functions.

Each of the letters making up ABOHZIS stands for a certain category: A: general physical condition; B: upper extremities; O: lower extremities and back; $\mathrm{H}$ : hearing; $\mathrm{Z}$ : sight; I: intelligence; S: mental stability.

If a candidate is declared unlit for military service, physicians are required to state the reason by indicating a code in accordance with the MKR list and the ABOHZIS classification.

The technical scope for assessing the quality of military medical examination is covered in paragraph 1.2. The most important aspects to measure the quality of the medical examination are reproducibility and validity. The reproducibility indicates to what extent the examination produces the same results if held at different moments, or performed by different physicians. In the case of military medical examinations this aspect may be determined by establishing to what extent the physicians perforning the examinations agree in their assessment of conscripts' medical fitness for military service.

Reproducibility is a precondition for a valid medical examination. Its validity indicates to what extent the medical examination can be used to assess correctly the fitness of those undergoing 
the examination. Through lack of information concerning those who fail, the possibilities for assessing the validity of an examination are limited. It is only possible to establish the extent to which conscripts on duty are discharged for medical reasons. This gives an indication of the predictive value of the medical examinations. Predictors of this medical dysfunctioning can be established, which enables predictions of medical dysfunctioning to be improved, using risk profiles. The investigation focuses on the predictive value and the medical examination's reproducibility, which led to the following questions:

To what extent is it possible to predict medical dysfunctioning in military service?

To what extent are military medical examinations reproducible?

On the basis of data from the medical information system, the first question is answered in chapter 2. Paragraph 2.1 describes the possibilities for medical examination and re-examination of conscripts.

A group of 118,716 conscripts was followed from the beginning (1987) to the end of this course of (re-)examination. Despite extensive medical selection, 6 percent of these conscripts on duty in the RNLA are discharged for medical reasons.

Further investigation into medical dystunctioning is described in paragraph 2.2. It contains the results of the retrospective cohort investigation of 8,714 conscripts who underwent a medical examination in 1989 and a year later in 1990 when they were called up for military service in the RNL.A.

Most of those who were discharged from military service were declared unfit because of disorders of the lower extremities and the back, or because of insufficient mental stability.

Using logistical regressive analysis, risk profiles were sought that can predict these two sorts of dysfunctioning before conscripts enter military service.

Predictors of dysfunctioning due to disorders of the lower extremities and back include: esiablishing a functional restriction during the first medical examination on the grounds of disorders of the lower extremities and the back which did not initially seem to justify rejection on medical grounds; or undergoing a medical re-examination, after having been found temporarily unfit during the firsit medical examination; and/or undergoing an extra examination on the basis of a case history form immediately prior to conscripts' actual enlistment. Prognostic factors of dysfunctioning due to a lack of mental stability include establishing a mental disorder during the first medical examination which did not seem to have to lead to rejection on medical grounds; and/or having dual nationality; and/or ending up in drafts with a smaller supply of conscripts than in other drafts.

Profiles, based on these predictors, can be used to calculate the risk of conscripts' dysfunctioning owing to disorders of the lower extremities (including the back) or insufficient mental stability before they are called up for military service.

It applars that if such an extra selection method is applied, the number of the conscripts who are discharged for medical reasons can to some extent be reduced.

In response to this investigation, there has been a discussion on the advantages and disadvantages of this selection method.

This discussion was held in the 'Tijdschrift Sociale Gezondheidszorg' (Journal of Social Health) and has been incorporared in Appendices 1, 2 and 3.

\section{Keuren is Mensenwerk}


Chapter 3 shows the results of research which was done to investigate the reproducibility of medical examination in the RNLA.

Firstly, in paragraph 3.1 the data of the 1993 medical examinations are analyzed. Just over half of the conscripts who fail the medical examination do so because of disorders that fall under the categories of general physical condition or disorders of the lower extremities (including the back).

Variation can be observed between the different examination boards as well as between the physicians who conduct these examinations. This variation is reflected most clearly in the assessment of conscripts rejected due to disorders of the lower extremities and the back. The variation can be partly explained due to procedural differences between examination boards with regard to candidates' varying sight and hearing abilities.

The remaining variation between the different boards is due to the differences between individual medical examiners.

Paragraph 3.2 describes an investigation into the degree of consensus among physicians concerning the medical fitness of conscripts.

Some 36 physicians reviewed the records of 14 cases in which it was difficult to assess the fitness because of disorders of the lower extremities and the back.

Agreement was calculated by means of Cohen's kappa. The kappa value can range from 0 to 1. A value of 0-0,40 indicates poor agreement. The agreement on fitness, as well as on the classification with regard to the lower extremities and the back are low, with kappa values ot 0.20 and 0.17 respectively.

The influence of the conscription board on inter-observer agreement appears to be small, because the agreement between physicians within a single conscription board varies between 0.19 and 0.4 .0 where candidates' fitness is concerned and between 0.13 and 0.35 for the classification of the lower extremities and the back.

Consultation between colleagues and steering by the head of the medical commission does not result in physicians of the same board consistently applying the same policy. It also appears that contextual information has a negative effect on inter-observer agreement. In the assessment of candidates' fitness, kappa is 0.07 for cases with contextual information, whereas this value was 0.35 for cases without contextual information. When we look at the classification of the lower exiremities and the back, the kappa values were 0.07 and 0.21 respectively. To improve inter-observer agreement the idea of carrying out job-specific medical examinations might be considered. Another idea would be for the physicians to specialize in the examination of candidates for specific functions or groups of functions. Furthermore, more attention could be given to consultation among colleagues and to courses for medical examiners, especially those 'breaking in' new physicians.

An additional investigation is described in paragraph 3.3, which relates to the degree of agreement among physicians who carry out periodical medical examinations of regular RNLA personnel. In this study 12 randomly selected cases were presented to two physicians. The agreement between the original physician and the other two is established on the basis of Cohen's kappa. In these medical examinations the physicians not only gave an assessment of candidates' fitness and the ABOHZIS classification, but they also indicated medical restrictions. With respect to the ABOHZIS classification it can be observed that in the A category (general 
physical condition) kappa was 0.16 , in the $\mathrm{B}$ category (upper extremities) 0.52 and in the $\mathrm{O}$ category (lower extremities and back) 0.44 . The kappa values for the medical restrictions indicated in the $\mathrm{A}, \mathrm{B}$ and $\mathrm{O}$ categories were $0.67,0.74$ and 0.65 respectively.

This investigation also shows that the inter-observer agreement on the assessment of the fitness between the physicians is difficult to reproduce. The assessment of people's fitness therefore not only depends on their general health condition, but also on the examiner. The use of the ABOHZIS system does not contribute to periodical medical examinations of individual service personnel.

In the discussion (chapter 4) an attempt was made to establish to what extent the questions that were presented have been answered.

This investigation has shown that conscripts' medical dysfunctioning based on the $\mathrm{O}$ and $\mathrm{S}$ categories can be predicted, using risk profiles. The number of conscripts who dysfunction for medical reasons can therefore be reduced by this extra selection. However, only part of those who dysfunction for medical reasons were examined and the risk profiles did not lead to drastic improvements in the predictive value (from $91.9 \%$ to $92.3 \%$ ).

On the basis of written files it can be established that there was poor to moderate agreement between the physicians. This conclusion can be drawn after reviewing examination results of both conscripts and RNLA regular personnel. Despite the rcgulations and written guideline's the reproducibility of the military medical examinations appears to be limited. The scope for physicians to decide for themselves is an important feature in assessing someone's medical fitness for military service, for which the human factor is thus indispensible.

As a result of this investigation suggestions were made to improve the quality of the military medical examinations, including medical examinations for conscripts and regular personnel, as well as pre-employment medical examinations, all of which share the same basic principle. An important recommendation is made, namely to develop a system in which the military medical examinations are related to specific job descriptions. In such a system physicians could specialize in the examination for certain functions, such as infantrymen or drivers. In a job-related system to be further developed in the 'new' all-volunteer armed forces there will be no need for the ABOHZIS system, with its limited reproducibility.

The development of the functiongraph-somagraph fits well within the principle of job-related examination, because the physical demands of someone's job are compared to his/her physical condition.

Because of the reorganisation of the armed forces, further investigation is needed of the medical examination system of the 'new' regular personnel. Firstly, research in medical dysfunctioning within the professional army is necessary. If the examination system changes or if functional demands increase or decrease. dysfunctioning for medical reasons needs to be evaluated on a systematic basis, because this can serve as an indicator of the predictive value of medical examinations. Furthermore, research has to be done to investigate if job-related examinations yield higher reproducibility. The effect can be measured with simulating persons instead of written case histories. 
Throughout the investigation it was repeatedly noted that examination data exist with respect to the entire Dutch male population. The question arose as to whether these data can also be used for other than their primary purposes, namely as a basis for an investigation into the state of health of Dutch men of the age of 18 . It has appeared that studies were made in this areas in the past, partly as a result of the possibilities to combine these data with external databases. Although no medical examinations of conscripts are currently being carried out and privacy regulations do not allow external databases to be linked, retrospective research can always be carried out into the trends of the main disorders. It would be regrettable if, owing to the disappearance of conscription, this valuable source of information not to be used anymore. 


\section{LIJST MET AFKORTINGEN}

\section{ABOHZIS}

BBT

BLS

BOT

CHR

DINIMED

DWS

FuSO

GA

ICD

ICIDH

IR

$\mathrm{KC}$

KGO

$\mathrm{KL}$

KLU

KM

KMar

KNMG

$M D$

MGO

MKR

$\mathrm{OR}$

$\mathrm{P}$

PGO

PULHEMS

$\mathrm{RR}$

Se

$\mathrm{Sp}$

TO

VKC

VO

VOV

$V W+$

VW-

WAO

WIKL

WTA

WTZ
Nederlands classificatiesysteem

Beroepsmilitair met een verbintenis voor Bepaalde Tijd

Bevelhebber der LandStrijdkrachten

Beroepsmilitair met een verbintenis voor Onbepaalde Tijd

Centrale HerkeuringsRaad

Disfunctioneren om Nlet MEDische redenen

Defensie Werving en Selectie

Functiegram-Somagram

Geneeskundige Aangelegenheden

International Classification of Diseases

International Classification of Impairment, Disability and Handicaps

IndelingsRaad

KeuringsCommissie

Databestand Keuringen en Geneeskundige Onderzoeken

Koninklijke Landmacht

Koninklijke Luchtmacht

Koninklijke Marine

Koninklijke Marechaussee

Koninklijke Nederlandse Maatschappij tot bevordering der Geneeskunst

Medisch Disfunctioneren

Militair Geneeskundig Onderzoek

Militair KeuringsReglement

Odds Ratio

Prevalentie

Periodiek Geneeskundig Onderzoek

Angelsaksisch classificatiesysteem

Relatief Risico

Sensitiviteit

Specificiteit

Tijdelijke Ongeschikt

Voorzitter Keuringscommissie

Voorgoed Ongeschikt

Voorgoed Ongeschikt op Verklaring

Positieve voorspellende waarde

Negatieve voorspellende waarde

Wet op de ArbeidsOngeschiktheidsverzekering

Werkgroep Indelingseisen $\mathrm{KL}$

Wet Terugdringing Arbeidsongeschiktheidsvolume

Wet Terugdringing Zickteverzuim 


\section{DANKWOORD}

Op deze plaats een woord van dank aan alle mensen die op enigerlei wijze bijgedragen hebben aan de totstandkoming van dit proefschrift.

Mijn promotoren Prof. dr. H.J.M. Crebolder en Prof. dr. F. Sturmans bedank ik voor hun vertrouwen in mij en de begeleiding en steun die zij mij hebben gegeven.

Sinds het moment van kennismaking heeft Harry Crebolder mij met zijn stimulerende en stuwende kracht, door de wereld van het onderzoek geloodst. Te allen tijde kon ik bij hem terecht. Ook tijdens de afronding van dit proefschrift was zijn motiverende begeleiding onontbeerlijk.

De inbreng van Ferd Sturmans heeft mij tot steeds diepgaander onderzoek gedreven, met name door zijn kritische blik op de methodologische aspecten van dit onderzoek.

Ook bedank ik mijn co-promotor Frans van der Horst van wie ik de militaire keuringen vanuit een breder sociologisch perspectief heb leren bekijken.

Jan Joost Rethans bedank ik voor het idee om de overeenkomst tussen de artsen aan de hand van simulatiepatiënten te bestuderen. Dit lijkt een optie voor vervolgonderzoek.

Mijn dank aan Hubert Schouten mag uiteraard niet ontbreken. In alle rust heeft hij verschillende malen de statistische aspecten besproken. Zonder zijn computerprogramma was het niet zo goed gelukt om de mate van overeenkomst tussen meerdere beoordelaars te berekenen.

De beoordelingscommissie, in het bijzonder de voorzitter Prof. dr. F. Nijhuis, bedank ik voor het waardevolle commentaar.

Al mijn collega's van de afdeling Geneeskundige Aangelegenheden van de Directie Dienstplichtzaken wil ik zeker niet vergeten te bedanken.

Hans Smink, het hoold van de afdeling, die mij de mogelijkheid heeft gegeven te promoveren. Het was een fijne samenwerking, met name door de brainstormsessies.

Margo Friedericks heeft de eerste twee jaar als projectmedewerkster mijn activiteiten ondersteund. Met veel geduld heeft zij vele malen tabellen moeten herzien.

Philip Hothuis heeft mij in de wereld van dienstplichtkeuringen geintroduceerd. Bij het onderdeel over het medisch disfunctioneren heeft hij een niet te onderschatten rol vervuld.

Joost Jeurissen en John Bexkens hebben mij wegwijs gemaakt in het medische registratiesysteem.

John de Raad heeft mij de mogelijkheid geboden artsen die keuringen bij beroepsmilitairen verrichten in het onderzoek te betrekken. Hiervoor ben ik hem erkentelijk.

Dit onderzoek was niet mogelijk geweest zonder de medewerking van de artsen van zowel alle indelingsraden als van de keuringsraden.

verder bedank ik alle collega's die mij hebben geholpen door bijvoorbeeld de invoer van data of het lezen van conceptteksten.

Tenslotte wil ik mijn ouders bedanken voor de stimulerende invloed. En niet te vergeten mijn partner Ap Verheggen, die mij van het begin tot het eind heeft gesteund. Zonder zijn steun had ik dit proefschrift niet kunnen voltooien. 


\section{CURRICULUM VITAE}

Petra Reulings werd op 30 juni 1966 geboren in Kerkrade.

Na de lagere school in Diemen, volgde zij haar middelbare school opleiding (VWO) aan het Antonius Doctor College te Kerkrade.

Vanaf 1985 tot 1991 studeerde zij Gezondheidswetenschappen aan de Rijksuniverisiteit Limburg met de afstudeerrichtig Gezondheidsvoorlichting en Opvoeding (GVO). Haar afsiudeersproject verrichtte zij bij het Instituut voor Revalidatievraagstukken te Hoensbroek. Het onderzoek had betrekking op de effectiviteit van een interdisciplinair pijnbehandelingsprogramma in termen van medische consumptie.

In 1991 en 1992 volgde zij een automatiseringsopleiding 'Ontwerper Kennissystemen'. In juli 1992 startte zij als wetenschappelijk beleidsmedewerker bij de aldeling Geneeskundige Aangelegenheden van de Directie Dienstplichtzaken van het Ministerie van Defensie te Kerkrade. Het project had als doel de kwaliteit van de dienstplichtkeuring te evalueren en zonodig aanbevelingen ter verbetering van de kwaliteit aan te reiken.

Dit proefschrift is het resultaat van de activiteiten tijdens dit project.

Per 1 juli 1996 werkt zij als onderzoeker bij de sectie Beleidsonderzoek van de afdeling Gedragswetenschappen bij de Centale Dienst Personeel en Organisatie van de Koninklijke Landmacht van het Ministerie van Defensie te Den Haag. 


\section{BIJLAGE 1}

Gepubliceerd als: Dijk FJH van, Weide W van der. Zet 'm op, scoor een job. Tijdschr Soc Gezondheidsz 1995;73:503-4.

\section{Zet 'm op, scoor een job}

Een paar maanden geleden verscheen 'Risicoselectie op de Nederlandse arbeidsmarkt'. Uit deze studie blijkt dat bijna de helft van de onderzochte ondernemingen strenger is gaan selecteren vanwege nicuwe financiële risico's, zoals de premieditterentiatie binnen de werknemers. Voor deze selectie worden bijvoorbeeld sollicitatieformulieren gcbruikı met gezondheidsvragen. Ook worden er meer aanstellingskeuringen aangevraagd, met name bij middelgrote ondernemingen. Bij grote bedrijven laat men aanstellingskeuringen juist vaker achterwege vanwege twijfels over het nut ervan, of worden aanstellingskeuringen selectiever en meer functiegericht toegepast.

Eenduidige cijfers over percentages afkeuringen ontbreken overigens. Volgens een opgave van keurende bedrijfsartsen is dit percentage afkeuringen toegenomen van $1,8 \%$ in 1991 tot $5,0 \%$ in 1993. Bij huisartsen bleef het percentage afkeuringen in deze periode ongeveer gelijk ( $1,4 \%$ respectievelijk $1,2 \%$ ). Opvallend is dat bedrijven over hclzclfde tijdvak juist een daling van het percentage afgekeurden rapporteren.

Het causale verband tussen de toename van de risicoselectie en de invoering van de financiëlc prikkels wordt door de werkgevers zelf onomwonden gelegd en blijkt ook uit de sterke neiging tot risicoselectie bij bedrijven met een hoog verzuim en met grotere linanciële risico's '. De voorgenomen uitbreiding van de 'eigen risico'-periode tot 52 weken zal vermoedelijk leiden tot cen strengere selectie.

Op de KNMG-conferenties 'Artsen en arbeidsongeschiktheid' in 1991 en 1993 werd reeds met klem gewaarschuwd voor 'risicowering via aanstellingskeuringen'. Om ongewenste praktijken tegen te gaan is vervolgens een protocol voor aanstellingskeuringen ontwikkeld ? dat inmiddels niel alleen door de beroepsorganisaties van bedrijfs- en huisartsen is onderschreven, maar ook door de werkgevers- en werknemersorganisaties en door de arbodiensten.

De laatste jaren word door veel praktijkdeskundigen en onderzoekers getwijfeld aan de kwaliteit van de verrichte aanstellingdkeuring. In 1993 verscheen het proefschrift van De Kort, waaruit blijkt dat functiegericht keuren nog geen standaardpraktijk is en dat de betrouwbaarheid en validiteit van de keuring veel te wensen overlaat'. De effectiviteit van een op selectie gerichte keuring blijkt zeer gering te zijn als het gaat om de preventie van arbeidsgebonden aandoeningen, ziekteverzuim en arbeidsongeschiktheid. Oftewel: het voorspellen hiervan is bijzonder moeilijk, omdat deze gebeurtenissen maat in beperkte mate afhankelijk zijn van iemands gevoeligheid en gezondheid.

'Zet ' $m$ op scoor een job'; lezen we op de reclameborden boven een foto van een in militair uniform gestoken fotomodel. Maar krijgt iedereen die kans? In dit nummer van het TSG wordt een onderzoek gepresenteerd over de slectie van dienstplichtigen om medisch disfunctioneren tijdens de dienstplichtperiode te beperken ". De militaire dienstplicht behoort binnenkort tot de verleden tijd. Toepassing van de in dit artikel gepresenteerde instrumenten. 
argumentatie en beleidsaanbevelingen bij een beroepsleger of in het bedrijfsleven, lijki echter niet uitgesloten.

Stel dat de voorgestelde beleidssuggesties realiteit wordenbij de selectie van beroepsmilitairen of andere werknemers. Dan zouden na een eerste selectieronde bijvoorbeeld nog eens $4 \%$ van de instromers (in het artikel 371 van de 8714 mensen) extra worden afgekeurd om te voorkomen dat $0,4 \%$ van hen ( 36 mensen) op een termijn van ruim een jaar arbeidsongeschikt wordt vanwege aandoeningen van de onderste extremiteiten en de rug. We spreken dan over een predictieve waarde van de positieve testuitslag van ongeveer $10 \%$. Met deze strenge criteria worden slechts 36 van de 243 personen ontdeki die vanwege genoemde aandoeningen zullen uitvallen. Ook de sensiviteit van deze extra keuringsprocedure is erg laag. Uit het artikel " blijkt dat de mogelijkheden om psychisch disfunctioneren te voorkómen door selectie aan de poort nog beperkter zijn. Gegeven 8714 intreders, zouden zes mensen extra moeten worden afgekeurd om één van de 281 'disfunctioneerders' te voorkomen. De verscherpte selectiecriteria lijken meer kwaad dan goed te doen.

Een strenger afkeuringsbeleid kan leiden tot situaties zoals beschreven in Medisch Contact s. waar een afkeuring wordt vermeld op grond van 'te tenger postuur' en 'onuitgerijpte persoonlijkheid'. De eerste afwijzing in het jong-volwassen leven is hiermee binnen. Een dergelijke aanpak is bovendien niet te rijmen met het maatschappelijke streven naar integratie in het arbeidsproces van mensen met c'n chronische ziekte of handicap *.

Selectie (risicowering) door middel van aanstellingskeuringen is populair bij werkgevers en professionals die er niet bij stil (willen) staan dat we slechts zelden beschikken over een valide en danvaardbaar sclecic-instrument. Pleidooien voor strenger keuren dragen er bovendien aan bij dat op de wijze de oorzask van ziekteverzuim eenzijdig bij de werknemers zelf wordt gelegd. Dit voorkomt dat wordt gewerkt aan een verbetering van arbeidsomstandigheden en werkverhoudingen.

In geval van veiligheidsrisico's voor derden moet soms noodgedwongen een kwalitatiei minder gocde test worden geaccepterd, mar ook in die gevallen dient de aanstellingskeuring te voldoen aan van tevoren helder omschreven eisen betreffende validiteit en predictieve waarde van de positieve testuitslag. De verhouding tussen de kosten en de opbrengsten van selectie, beide breed geformuleerd, dient steeds kritisch te worden onderzocht.

\section{Literatuur}

I College van Toezicht Sociale Verzekeringen. Risicoselectie op de Nederlandse arbeidsmarkt. Zoetermeer, 1995.

2 Koninklijke Nederlandse Maatschappij tot bevordering der Geneeskunst. Protocol Aanstellingskeuringen. Utrecht: KNMG, 1995.

3 Kort WLAM de. Personnel selection through pre-employment medicals [proefschrift]. Universiteit van Amsterdam, 1993.

4 Reulings PG.J, Sturmans F, Crebolder HFJM, e.a.. Prognostische factoren voor het medisch disfunctioneren tijdens militaire dienst bij de Koninklijke Landmacht. Tijdschr Soc Gezondheidsz 1995:73:505-11.

5 Onuitgerijpt (Praktijkperikel). Med Contact 1995:50:585.

6 Ministerie van Volksgezondheid, Welzijn en Sport. Gezond en Wel, het kader van het Volksgezond= heidsbeleid 1995-1998. Den Haag, 1995.

\section{Keuren is Mensenwerk}




\section{BIJLAGE 2}

Gepubliceerd als: Reulings PGJ, Smink HAJ, Horst F.G. van der. Als je selecteert, doe het dan niet verkeerd. Tijdschr Soc Gezondheidsz 1996:74:78-9. Commentaar op: Tijdschr Soc Gezondheidsz 1995:73:503-4.

\section{Als je selecteert, doe het dan niet verkeerd}

De laatste tijd staan, door invoering van de Wet Terugdringing Ziekteverzuim en Wet Terugdringing Arbeidsongeschiktheid, aanstellingskeuringen en de selectie van personeel in de volle belangstelling. Ook is dat het geval blijkens dit tijdschrift onder het redactioneel stuk 'Zet ' $m$ op, scoor een job' '.

Op advies van het Ministerie van Sociale Zaken en Werkgelegenheid heeft de KNMG een Protocol Aanstellingskeuringen opgesteld. Volgens dit Protocol dient de huidige belastbaarheid van de keurling ten opzichte van de belasting van de betreffende functie te worden beoordeeld ${ }^{2}$.

Daarbij wordt risicowering als ongewenst beschouwd. Onderzoek heeft namelijk uitgewezen dat de voorspellende waarde van de aanstellingskeuring beperkt is. Men zou zelfs van de aanstellingskeuring (als zodanig) kunnen afzien ?

Echter bij functies waar de gezondheid en veiligheid van de betrokken persoon of derden in gevaar is, is een aanstellingskeuring onontkoombaar.

Immers, hierbij gaat het niet om het financiële risico van de werkgever, maar om het risico op gezondheidsschade van de persoon die de functie uitoefent en/of derden (hetgeen uiteindelijk ook financiële risico's met zich meebrengt). Dit speelt een rol bij politie, brandweer en niet te vergeten het leger. Juist voor deze populaties dient, ondanks de beperkte voorspellende waarde, verder onderzoek te worden gedaan naar bruikbare instrumenten om beter te selecteren. Binnen het Ministerie van Defensie zijn ontwikkelingen gaande om de personeelsselectie te verbeteren. Mede tegen deze achtergrond is het onderzoek naar prognostische factoren van het medisch disfunctioneren tijdens de militaire dienst opgezet ${ }^{4}$. Met dit onderzoek is getracht meer inzicht te krijgen in factoren die het medische disfunctioneren van dienstplichtigen vór opkomst kunnen voorspellen. Op grond van de resultaten zijn aanbevelingen gedaan om het medische disfunctioneren tijdens dienstvervulling te verminderen.

Een cohort goedgekeurden, die de dienstplicht hebben vervuld, is onderzocht. Ondanks de keuringen vóór opkomst, zijn alsnog 705 van de 8714 dienstplichtigen in diensi om medische redenen afgekeurd.

Bekeken is in hoeverre het medisch disfunctioneren vermindert als de groep dienstplichtigen die voldoet aan bepaalde risicoprofielen, niet in dienst komt. Hierbij gaat het om een verhoogd risico om tijdens de dienstvervulling medisch te disfunctioneren, als gevolg van aandoeningen van de onderste extremiteiten en de rug en psychische stoornissen.

Om te beoordelen of deze extra selectie een positieve toevoeging vormt voor de huidige keuring, dient - naast de berekening van de voorspellende waarde van de keuring in combinatie met de extra selectie - een afweging te worden gemaakt tussen de door de betrokkenen ervaren schade door een onterechte uitsluiting, ten opzichte van de gezondheidsschade die door de exira selectie kan worden voorkomen. 
Ter vermindering van het aantal disfunctioneerders is voorgesteld om 371 personen uit te sluiten voor de militaire dienst, zodat voorkomen zou worden dat 36 personen schade aan hun gezondheid ondervinden.

Gezien de huidige houding ten opzichte van de militaire dienst wordt uitsluiting voor de militaire dienst om medische redenen overwegend niet als negatief ervaren, maar als 'mazzel'. In het verlengde daarvan moet men zich realiseren dat de 8714 personen die in dienst komen een selectie is van een groep van 50.000 keurlingen die het dienstplichtraject hebben doorlopen. Naar ons weten is nog geen actiegroep opgericht van mensen die wel in dienst willen. Ook dient men vraag en aanbod te bezien s. Net zoals bij goederen die niet schaars zijn is de keuzevrijheid groot en waarom zou men dan in dit geval niet kiezen voor de beste dienstplichtigen.

Tenslotte mogen we niet vergeten dat de dienstplicht wettelijk verplicht is. Dit brengt voor de overheid grote verantwoordelijkheid mee voor de gezondheid en veiligheid van betrokkenen, die - naar wij veronderstellen - voor het merendeel de militaire dienst niet uit vrije wil vervullen.

Het risicoprofiel is specifiek voor dienstplichtigen en niet zonder meer te gebruiken voor andere militairen, hetgeen wordt gesuggereerd in het redactioneel van TSG.

De door ons voorgestelde selectic blijft relevant, omdat het dienstplichtsysteem in de toekomst bij oorlogsdreiging of calamiteiten weer actucel kan worden.

Niettemin is het wenselijk dat ons onderzoek herhaald wordt voor beroepsmilitairen.

Hierbij dient rekening te worden gehouden met factoren die bij deze populatie een rol spelen, zoals de bewuste carrière keuze van de beroepsmilitair.

Indien dit onderzoek tot dezelfde uitkomsten zou komen, zou dit mogelijk tot andere aanbevelingen leiden omdat andere afwegingen gemaakt zullen worden. Voor de hand liggend is dat een afkeuring dan wel als een persoonlijke schade worden ervaren.

Als men bij een keuring personeel moet selecteren vanwege het gezondheids - en veiligheidsrisico, dient deze selectie derhalve te geschieden aan de hand van op onderzoek gebaseerde criteria en overwegingen die zijn toegesneden op de populatie.

\section{Literatuur}

l Van Dijk en van der Weide, Zet 'm op score eer job, redactioneel Tijdschr Soc Gezondheidsz 1995;73:503-4.

2 Koninklijke Nederlandse Maatschappij tot bevordering der Geneeskunst Protocol aanstellingskeuringen. Utrecht: KNMG, 1995.

3 Kort WLAM de. Personnel selection through pre-employment medicals [proefschrift]. Universiteit van Amsterdam, 1993.

4 Reulings PGJ, Sturmans E, Crebolder HFJM e.a.. Prognostische factoren voor het medisch disfunctioneren tijdens militaire dienst bij de Koninklijke Landmacht. Tijdschr Soc Gezondheidsz 1995;73:505-11.

5. Duindam, Militaire dienstplicht: een economische analyse van de personeelscomponent in de krijgsmachi [proefschrift]. Rijksuniversiteii Limburg. 1995.

\section{Keuren is Mensenwerk}




\section{BIJLAGE 3}

Gepubliceerd als: Dijk FJH van, Weide W van der. Repliek. Tijdschr Soc Gezondheidsz 1996;74:504.

\section{Repliek}

Wij zijn eens over aantal onderwerpen; op een paar aspecten willen wij kort reageren. Ons redactioneel over risicoselectie door middel van aanstellingskeuringen gaat in op een algemeen probleem aan de hand van een voorbeeld, namelijk mogelijkheden voor selectie van dienstplichtigen. De auteurs van het oorspronkelijk artikel geven zelf aan dat de relevantie van hun zoektocht naar prognostische factoren gelegen is in het feit dat ze van belang kunnen zijn voor andere keuringen, zoals voor beroepspersoneel van de Koninklijke Landmacht en de overige krijgsmachtdelen. Wij hebben slechts aan willen geven dat er een groot gevaar schuilt in het strenger keuren van werknemers.

Bij de opmerking dat een aanstellingskeuring onontkoombaar is bij functies waar de gezondheid en veiligheid van de betrokken persoon of derden in gevaar is, missen wij de noodzakelijke toevoeging dat dit uitgangspunt alleen geldt wanneer cen valide en maatschappelijke aanvaardbare methode voorhanden is. Dat de afweging tussen kosten en opbrengsten bepaald wordt door de specifieke context staat buiten kijf, zoals wij ook in onze conclusie hebben aangegeven; kosten voor het individu, zoals de kans op het onterecht afgewezen worden, en opbrengsten in het voorkomen van gezondheidsschade. Wij zijn het eens met de constatering dat het onderzoek herhaald moet worden voor beroepsmilitairen, zeker als gekozen wordt voor de optie 'strenger keuren'.

Verder blijft een feit dat, ondanks een extra strenge keuring waardoor 36 mensen worden behoed voor gezondheidsschade, de overgrote meerderheid van de medische disfunctioneerders toch aangenomen zal worden. Ligt het dan niet meer voor de hand om het onderzoek en beleid veel meer te richten op de oorzaken van deze uitval 'op het werk'? Een preventieve aanpak dus. De aandacht kan vervolgens gericht worden op aanvullende maatregelen dien genomen kunnen worden wanneer toch gezondheidsproblemen ontstaan, zoals begeleiding, training. omscholing of overplaatsing naar een meer passende functic. Deze route lijkt ons veel vruchtbaarder, zeker wanneer we denken aan beleid voor cen leger dat geheel uit beroepsmilitairen bestaat.

De stelling 'waarom zou men in dit geval niet kiezen voor de beste dienstplichtige?' vraagt ook om commentaar. In het KNMG-Protocol Aanstellingskeuringen staat: 'De aanstellingskeuring is geen selectie-instrument tussen sollicitanten. Zij vormt het sluitstuk van de sollicitatieprocedure'. Wij doen een beroep op alle betrokkenen bij aanstellingskeuringen om grote zorgvuldigheid te betrachten in dezen. Het is geen taak voor (bedrijfs)artsen om de beste mensen voor een baan te selecteren. Deze selectie moet overgelaten worden aan directie en personeelszaken. Dit geldt naar onze mening ook voor de procedure bij dienstplichtigen. 



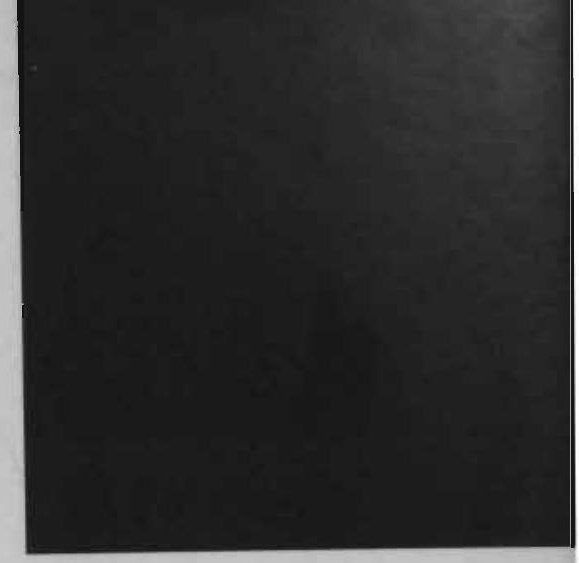

